\title{
PARTICLE FLUX IN THE WESTERN BLACK SEA IN THE PRESENT AND OVER THE LAST 5,000 YEARS: TEMPORAL VARIABILITY, SOURCES, TRANSPORT MECHANISMS
}

\author{
by \\ Bernward Josef Hay \\ Vordiplom, Georg-August Universität, Göttingen, F.R. Germany, 1977 \\ M.S., Cornell University, Ithaca, NY, 1982 \\ SUBMITTED IN PARTIAL FULFILLMENT \\ OF THE REQUIREMENTS FOR THE DEGREE OF \\ DOCTOR OF PHILOSOPHY \\ at the \\ MASSACHUSETTS INSTITUTE OF TECHNOLOGY \\ and the \\ WOODS HOLE OCEANOGRAPHIC INSTITUTION
}

September, 1987

@Bernward J. Hay, 1987

The author hereby grants permission to MIT and WHOI to reproduce and distribute copies of this thesis document in whole or in part.

Signature of Author

Joint Program in Oceanography, Massachusetts Institute of Technology (Department of Earth,

Atmospheric, and PlanetanySciences) and Woods Hole Oceanographic Institution, September 10, 1987

Certified by

Susumu Honjo, Thesis Supervisor

Accepted by

Marsha McNutt, Chairman, Joint Committee for Geology and Geophysics, Massachusetts Institute of

TechnologyMoods Hole Oceanographic Institution 
-ii- 
TABLE OF CONTENTS

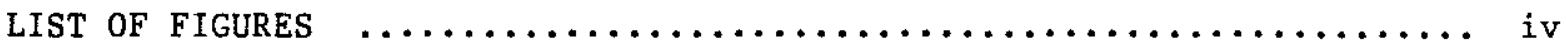

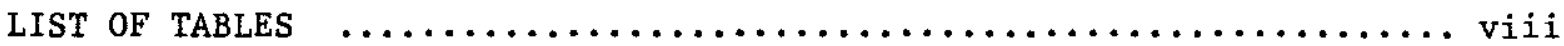

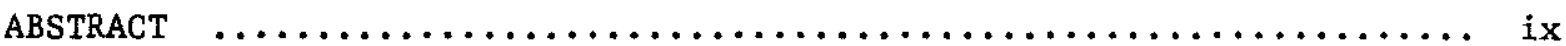

ACKNOWLEDGMENTS $\quad \ldots \ldots \ldots \ldots \ldots \ldots \ldots \ldots \ldots \ldots \ldots \ldots \ldots \ldots \ldots \ldots \ldots \ldots \ldots \ldots \ldots$

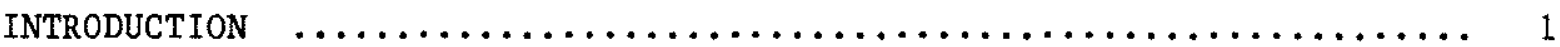

CHAPTER 1. SEASONAL CYCLICITY OF LITHOGENIC FLUXES IN THE

SOUTHWESTERN BLACK SEA $\ldots \ldots \ldots \ldots \ldots \ldots \ldots \ldots \ldots \ldots \ldots \ldots$

CHAPTER 2. PARTICLE FLUX IN THE WESTERN BLACK SEA THROUGHOUT

THE PAST 5,000 YEARS WITH COMPARISON OF THE PRESENT

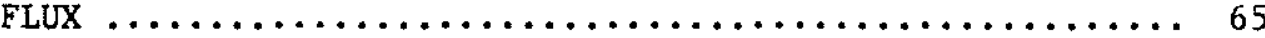

CHAPTER 3. SEASONAL VARIABILITY IN THE TITANIUM TO ALUMINUM RATIO IN

THE PARTICULATE MATTER OF THE BLACK SEA: POSSIBLE TRACER

FOR DANUBE INPUT $\ldots \ldots \ldots \ldots \ldots \ldots \ldots \ldots \ldots \ldots \ldots \ldots \ldots \ldots \ldots$

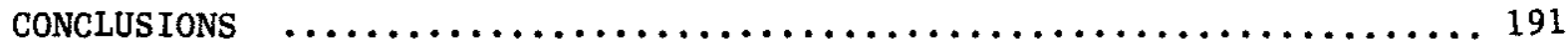

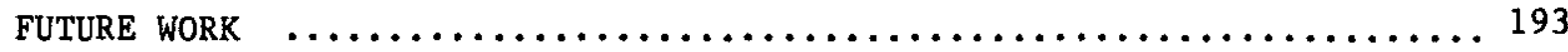

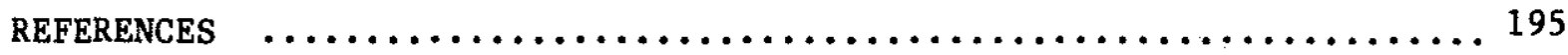




\section{L.IST OF FIGURES}

Figure 1: Location map of all the sites for all the samples used in this study.

Figure 2: Detailed location map of the sediment trap mooring site BS

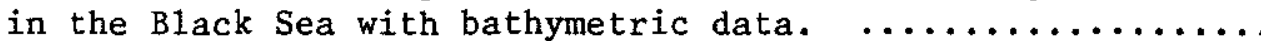

Figure 3: Schematic diagram of the sediment trap mooring array used in the deployment of two MARK $\mathrm{V}$ sediment traps at $250 \mathrm{~m}$ and $1,200 \mathrm{~m}$ on the abyssal plain in the Black Sea at station BS.

Figure 4: Schematic flow-diagram of the laboratory processing and analysis of the Black sea sediment trap samples. ...........

Figure 5: Timemseries transition of total and major component fluxes compared between the $250 \mathrm{~m}$ and $1,200 \mathrm{~m}$ traps over the deployment period (October 28, 1982 to April 5, 1985).

Figure 6: Average monthly river discharge of the rivers Kocacay, Sakarya Nehri, and Danub

Figure 7: Section of LANDSAT 5 image, Band 2, from Apri1 27, 1984, showing the plume of suspended particles at the mouths of the rivers filyos (large) and Kocacay (small) relative to the trap station BS.

Figure 8: Wind stress (3-day average) calculated from wind speed and wind direction at the weather station Amasra, Turkey. ......

Figure 9: Ratios and percent distributions of major components of the particle flux.

(a) Organic carbon/carbonate plus biogenic silicate ratio

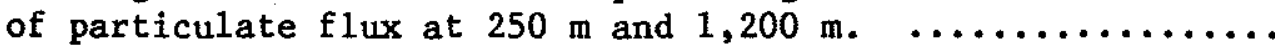

(b) Percent distribution of the carbonate and biogenic silica fluxes within the total particle flux at $250 \mathrm{~m}$ and $1,200 \mathrm{~m}$.

(c) Percent distribution of 1ithogenic and non-1ithogenic flux of the total particle flux at $250 \mathrm{~m}$ and $1,200 \mathrm{~m}$. .....

Figure 10: Cross-correlation between the organic carbon/carbonate plus biogenic silicate ratio of the $250 \mathrm{~m}$ and $1,200 \mathrm{~m}$ trap for Phase I in 1983. 
Figure 11: Conceptual diagram of sediment sources and dispersal mechanisms along the southern Black Sea margin, near trap

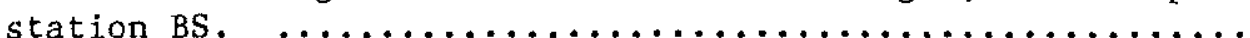

Figure 12: Dominant characteristics of the individual phases of the annual particle flux in the Black Sea. ............... 62

Figure 13: (a) Photomicrograph of unit I from core $18, \ldots \ldots \ldots \ldots \ldots$

(b) Photomicrograph of unit II from core $18 . \ldots \ldots \ldots \ldots \ldots 70$

Figure 14: (a) SEM photograph of a black lamina from sediment unit I

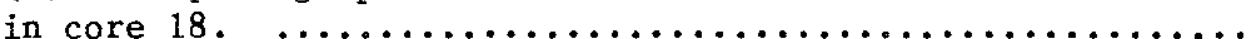

(b) SEM photograph of a white laminae from sediment unit I in core 18.

Figure 15: Stratigraphic cross-section of the three cores used for

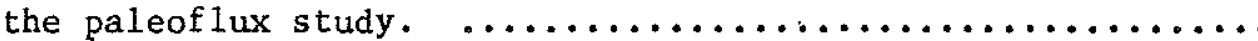

Figure 16: Schematic diagram of the method used in the determination of the postdepositional paleoflux (pPF) and the depositional paleoflux (dPF) for the laminated sediments of units I \&

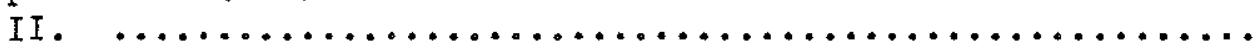

Figure 17: Schematic diagram of the computational step involved for the correction of the postdepositional paleoflux ( $\mathrm{pPF}$ ) for degradation of biogenic matter in order to obtain the depositional paleoflux (dPF).

Figure 18: Schema of the organic carbon budget for sediment unit I (taken from Deuser, 1971).

Figure 19: Organic carbon content $(\%)$ in cores $5 \& 18$ for unit I\& II.

Figure 20: Sedimentation rates for units I \& II for cores $5 \& 18$ as computed by dividing the average thickness of the sediment blocks used for the paleoflux study by their number of varve couplets.

Figure 21: Postdepositiona1 paleoflux (pPF) at core sites 5, 18, and 35 throughout the anoxic history of the Black Sea for the total, carbonate, noncombustible, and organic carbon pPF. .. 100

Figure 22: (a) Total postdepositional paleoflux ( $\mathrm{pPF}$ ) versus carbonate $\mathrm{PPF}$ in Black Sea sediment cores 5,18 , and 35 from 56 samples of sediment units I and II. 
(b) Total postdepositional paleoflux ( $\mathrm{PPF}$ ) versus the

noncombustible pPF from the same cores. ............... 102

(c) Total postdepositional paleoflux ( $\mathrm{pPF}$ ) versus the

organic carbon pPF from the same cores. .............. 102

Figure 23: Relative composition of the major particle flux components carbonate and lithogenics for the annual particle flux at site BS, the individual laminae in the deep basin cores, and the relevant river in the western Black Sea. ........... 112

Figure 24: Postdepositional sediment accumulation based on the particle $f 1 u x$ in the $1,200 \mathrm{~m}$ sediment trap at site BS. .... 114

Figure 25: Semi-quantitative determination of the major element concentrations of black laminae (a) and white laminae (b) using an EDX electron microprobe.

Figure 26: Coastal Zone Color Scanner (CZCS) image (channe1 3) of the

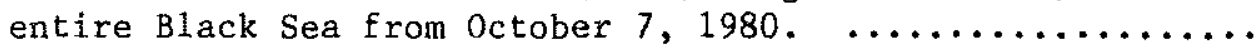

Figure 27: Temporal relationship between the depositional phases observed in the present-day particle flux at site BS, and the resulting black and white laminae in the sediment record.

Figure 28: Time-series data of the $\mathrm{Ti}$ and $\mathrm{A} 1$ flux at trap sites BS and BSC.

Figure 29: Correlation between the $\mathrm{T} \dot{\mathrm{i}}$ and $\mathrm{Al}$ flux in the samples of the $1,200 \mathrm{~m}$ sediment traps of sites BS and BSC.

Figure 30: Time-series data of the ratios Ti/Al, Lithogenics/A1, Carbonate/A1, $\mathrm{Si}_{\mathrm{blogen} / \mathrm{c}} / \mathrm{Al}, \mathrm{C}_{\text {org }} / \mathrm{A} 1, \mathrm{Cu} / \mathrm{A} 1$, and $\mathrm{Ni} / \mathrm{Al}$ for the $250 \mathrm{~m}$ and $1,200 \mathrm{~m}$ sediment trap samples from sites BS and BSC in $1984 / 85$ and 1986.

Figure 31: Particle flux at the sediment trap sites BS and BSC. ..... 146

Figure 32: Correlations between the Ti/A1 ratio and the Corg./A1, lithogenics/A1, $\mathrm{Si}_{\mathrm{blogen} / \mathrm{c}} / \mathrm{Al}$, and the carbonate/A1 ratios as well as correlations between the $\mathrm{Corg}$./A1 ratio and the

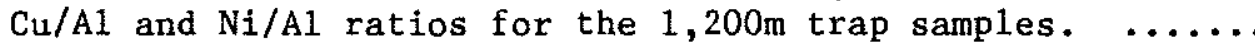

Figure 33: Distribution of illite/montmorillonite ratio in the surface sediments of the Black Sea, the Danube and the Western Anatolian rivers. 
Figure 34: Illite/montmorillonite ratios in the 1,200m sediment trap samples from site BS from samples collected between June 9 , 1983, and Apri1 15, 1984, by the R/V K. PIRI REIS. ....... 154 


\section{LIST OF TABLES}

Table 1: Summary of deployment schedules of sediment trap mooring array at station BS, water depth, trap location in the water column, and quality of the samples for all sediment trap deployments during the PARFLUX project in the Black Sea.

Table 2: Mean values for the $\mathrm{C}_{\circ \mathrm{rg}} /\left(\mathrm{CaCO}_{3}+\mathrm{Si}_{\mathrm{b} \text { । }}\right)$ ratio, the distribution of biogenic silica versus carbonate, and the distribution of 1ithogenics and non-1ithogenics for the three phases averaged for the entire $21 / 2$ year-long deployment.

Table 3: Table of assumptions and important values used for the salt correction and the calculation of the depositional paleoflux (dPF) from the postdepositional paleoflux (pPF).

Table 4: Average age of the sediment units I and II calculated by dividing the thickness of each sediment block by its number of varve couplets.

Table 5: Postdepositional paleof $1 \mathrm{ux}(\mathrm{pPF})$ in cores 5, 18, and 35. .. 104

Table 6: Correlation coefficients of the major paleoflux components for cores 5, 18, and 35 for unit $I$ and $I I . \ldots \ldots \ldots \ldots \ldots 105$

Table 7: Depositional paleoflux $(\mathrm{dPF})$ in cores 5,18 , and $35 . \ldots 110$

Table 8: Input of detrital and dissolved load by the major rivers surrounding the Black Sea, as well as characteristic Ti/Al

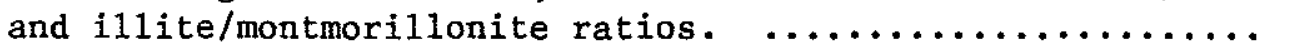

Table 9: Summary of Ti/Al ratios from various samples of the sediment traps, shelf sediments, and river sediments used in this study.

Table 10: Characteristic $\mathrm{Ti} / \mathrm{Al}, \mathrm{Cu} / \mathrm{Al}$, and $\mathrm{Ni} / \mathrm{Al}$ ratios in various

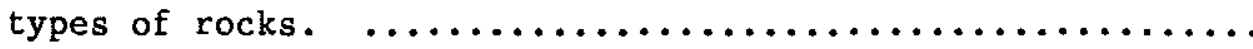

Table 11: Ti and Al concentration in planktonic organisms in the Black Sea (from Vinogradova and Koval'skiy, 1962). .......

Tab1e 12: "Excess" $\mathrm{Cu}, \mathrm{Ni}$, and $\mathrm{Ti}$ concentrations in the biogenic matter of the particle flux in the $1,200 \mathrm{~m}$ sediment trap at site BS for the time periods May/17/84-Sep/20/84 and Oct/23/84-Mar/22/85. 
PARTICLE FLUX IN THE WESTERN BLACK SEA

IN THE PRESENT AND OVER THE LAST 5,000 YEARS:

TEMPORAL VARIABILITY, SOURCES, TRANSPORT MECHANISMS

by

BERNWARD JOSEF HAY

Submitted to the Woods Hole Oceanographic Institution and Massachusetts Institute of Technology

in partial fulfillment of the requirements for the degree

of Doctor of Philosophy

\section{ABSTRACT}

The particle flux in the present and over the last 5,000 years was investigated in the Black Sea in a comparative study with samples from time-series sediment traps and laminated core sediments. The sediment trap samples were collected in the southwestern Black Sea over $21 / 2$ years at sampling intervals of about two weeks. Sediment core samples were derived from the central part of the western Black Sea, deposited throughout the last 5,000 years during which the Black Sea was anoxic. Conclusions from this study shed important light on temporal and regional variability of the particle flux in the Black Sea, dominant particle sources, and particle transport mechanisms. 
Dominant particle sources are biogenic matter (coccolithophorids of the species Emiliania huxleyi, diatoms, and silicoflagellates) and terrigenous matter from the Danube and nearby local rivers. The relative importance in the supply of these particles varies annually and can be grouped into three phases: Phase I (June-0ctober) coccolithophorid production, Phase II (November-January) - resuspension of coccoliths and terrigenous matter, and Phase III (February-May) river input of terrigenous matter and production of diatoms and silicoflagellates. Once removed from the surface water, particles settle rapidly at a rate of $115 \pm 70 \mathrm{~m} /$ day.

Regionally, the particle flux varies considerably. Throughout the last 1,000 years (sediment unit I), the particle flux (paleoflux) was more than 5 times larger in the central part of the western Black Sea than at present in the southwestern Black Sea, mostly because of the 11 times larger supply of coccoliths. The coccoliths were probably largely produced on or adjacent to the Danube shelf in the northwestern Black Sea and subsequently resuspended and transported offshelf by the fall storms. Terrigenous matter in the central part of the western Black Sea is higher by a factor of 3 compared to the southwestern Black Sea. The coccoliths are concentrated in the white laminae $\left(>93 \% \mathrm{CaCO}_{3}\right)$, and if the seasonal dynamics in the particle supply at the sediment trap site is taken as a standard, the white laminae would be deposited between about June and January. The black laminae contain largely terrigenous matter and form during the peak river discharge period between about February and May.

Compared to the last 1,000 years (unit I), the particle flux in the centra1 part of the western Black Sea between 1,000 and 5,000 years B.P. was smaller by a factor of three, because the salinity was still too low during this time period for the coccolithophorid Emiliania huxleyi to exist. The Black Sea was a fresh water environment before more than 5,000 years ago and gradually became brackish; Emiliania huxleyi became established after the salinity exceeded $11 \%$.

The terrigenous matter supply remained about constant over the last 5,000 years. The western Black Sea is dominated by terrigenous input from the Danube as revealed by the illite/montmorillonite ratio. Seasonally, the terrigenous matter from the Danube appears to be traceable in the southwestern Black Sea, as seen by the Ti/Al and illite/montmorillonite ratios in the sediment trap samples. 


\section{ACKNOWLEDGMENTS}

First and foremost, I am deeply indebted to Sus Honjo for his continuous and enthusiastic support and encouragement and for providing the motivating atmosphere to pursue new ideas. His patient confidence, which allowed me to participate in the Black Sea project, was greatly appreciated, as was his financial and logistical support.

I am very grateful to my thesis committee for its constructive advice at every stage of the program. Discussions with Kozo Takahashi gave at lot of insight into the particle dynamics of the ocean. Bill Curry was very instrumental in keeping me in touch with reality in sedimentological questions and viewpoints. As a Black Sea expert, Dave Ross provided useful criticism at various stages to smoothly integrate the present work into the existing data poo1 without losing originality. Ed Boyle devoted a lot of effort to attach a critical geochemical angle to my geological background. John Southard was very helpful with his guidance during the first part of the JP at MIT. In addition, Jake Peirson and Mary Athanis were very supportive with their guidance along the administrative avenues with its occasional potholes (i.e. registration deadlines) of the MIT/WHOI joint program. I further thank Lloyd Keigwin for chairing my thesis defense.

I was fortunate to work in a lab with responsible and vivacious people. The most important person to get me in touch with the hands-on aspects of particle collection on the ship and analysis in the lab was Steve Manganini, who also is just a great person to go on a cruise with. Emily Evans helped many times with logistical aspects during my studies. Amy Karowe was very helpful in the process of data collection and efficient data management, besides being a very supportive and pleasant housemate. Will Howard and Cindy Pilscaln expanded my understanding of marine sedimentation processes during numerous fruitful discussions. Vernon Asper spent considerable effort in showing me some of the ropes in the quantitative particle flux analysis. Ken Doherty and Rich Krishfield helped several times with technical aspects of the sediment trap moorings. Bonnie Woodward, Xia Qing, Susie Carter, and Abby Spencer were quick and very reliable in the chemical analysis of samples.

I am likewise very grateful to the collaborating oceanographic team from the University of Hamburg, namely Drs. Egon Degens, Venu Ittekkot, and Stephan Kempe, who allowed me to subsample cores from their cruise to the Black Sea with the R/V CHAIN in 1975, which became an integral part of this thesis. Numerous discussions with each of my German colleagues were very valuable for the better understanding of the subject matter. Venu, who also served on my advisor committee, additionally made arrangements for my participation on the successful first Arabian Sea cruise in 1986, which further broadened my practical knowledge in international oceanography. 
My gratitude extends also to my Turkish colleagues, Drs. Erol Izdar and Tosun Konuk, as we11 as their students, who were very supportive and extremely helpful in all logistical aspects of the data collection during the cruises in the Black Sea, besides being very pleasant colleagues to collaborate with. I also thank the officers and crews of the R/V Koca Piri Reis for their high level of support during the cruises to the Black Sea, as well as the Hydrographic Institution, Ankara, for providing their long-term weather and river records on northern Turkey for this study.

Further, I am very indebted to other colleagues who were instrumental in my studies. JoAnn Nicholson from Cornell University was a terrific collaborator in this Black Sea project on ship and in the lab with her high expertise in microbiology and biogeochemistry and her critical and thorough editing skills. Larry Poppe from the USGS supported me in the clay mineral analysis with his instrumentation. Don Bankston was invaluable with his expertise in elemental chemistry. John Jasper enlightened me many times in organic chemistry. Peter Schweitzer was a big help on numerous occasions in questions of quantitative data analysis. Glenn Jones and Alan Fleer allowed me to use their equipment several times. Kelly Luetkemeyer helped with the satellite image analysis on the remote sensing image processor. Steve Recca from MIT guided my research on the electron microprobe. LuPing Zou and Judy Commeau from the USGS helped a few times with the SEM analys is. My understanding of the Black Sea has been greatly improved by discussions with Hugh Livingston, Ken Buesseler, Peter Brewer, John Milliman, Frank Manheim, Ed Scholkovitz, Ian McCave, John Edmond, and others. Further, I would like to thank all my fellow students for providing a pleasant academic and social atmosphere for the prosperity of intellectual thoughts.

This research was funded by National Science Foundation Grant No. OCE-8417106 and office of Naval Research Contract No. N00014-85-C-0001. 
-xiii- 
-riv- 


\section{INTRODUCTION}

The Black Sea, the largest existing anoxic environment on earth, provides an opportunity to understand processes related to generation and sedimentation of particles at present and throughout its 5,000 year long history of anoxia. Many years of scientific study of the Black Sea water and sediments have provided a large set of data and hypotheses that elucidate the recycling and deposition of materials. However, the important link between particle generation and burial in the sediment still remains a critical part in our understanding of the sedimentation processes in the Black Sea and in other anoxic ocean environments.

By the principle of uniformitarianism, the Black Sea serves as the best modern analog to anoxic oceans in the past history of the earth (e.g. Degens and Stoffers, 1976; Berry and Wilde, 1978) and thus sheds light on the chemical and sedimentological evolution of the early atmosphere and oceans (Ho1land, 1984). The Black Sea also helps us to better understand the processes occurring in global oceans during the "Oceanic Anoxic Events" in the Late Jurassic and Cretaceous (Fischer and Arthur, 1977; Schlanger and Jenkyns, 1976; Ryan and Cita, 1977; Force, 1984). Widespread anoxia during these time periods was explained by an expanded oxygen-minimum zone which led to extensive deposition of organic-rich black muds on continental slopes and basin floors. These "Oceanic Anoxic Events" are of great economic importance since they are believed to have generated about $85 \%$ of the wor1d's known oil reserves 
(Tissot, 1979), even though they only occurred during $17 \%$ of Phanerozoic time (Demaison and Moore, 1980). Sediments deposited under anoxic conditions are of ten characterized by fine annual laminations and a high concentration of organic matter (Degens and Stoffers, 1976). A completely euxinic benthic environment provides perfect preservation of chronological events at the bottom, and a comparative study of flux material is important in understanding the mechanism and history of the genesis of particles in the water column.

\section{Brief history of research in the Black Sea}

The Black Sea is characterized by unusual chemical and microbiological properties owing to its stratified anoxic deep waters. Scientific exploration of the Black Sea started with Russian scientists as early as one hundred years ago with a series of cruises led by Andrusov $(1890,1893)$. This effort was followed by a more extensive and interdisciplinary expedition by Arkhangel'skiy and Strakhov in the late 1920 's and 1930's (Arkhangel'skiy and Strakhov, 1932, 1938). A compilation of notes of the first modern geochemistry study was made by Strakhov in 1954. The 7-week-1ong R/V Atlantis II cruise in spring of 1969 was a landmark in modern Black Sea oceanography (Degens and Ross, eds., 1974). This cruise was followed by a shorter $R / V$ chain cruise in 1975, where a number of undisturbed, laminated cores were taken with a specially engineered gravity corer for varve chronological studies 
(Degens et al., 1980). In the same year, the Glomar Challenger Leg $42 \mathrm{~B}$ also made an important contribution to further understand the geological evolution of the Black Sea in relation to the history of the Euro-Russian Massif (Ross and Neprochnov, 1978).

\section{Background}

The Black Sea is an enclosed basin with an area of about 423,000 $\mathrm{km}^{2}$ including the Sea of Azov $\left(38,000 \mathrm{~km}^{2}\right)$; its volume amounts to $534,000 \mathrm{~km}^{3}$. Most of the Black Sea is over two kilometers deep (max. depth: 2,206 m). It has a sill depth of about $50 \mathrm{~m}$ in the Bosporus, connecting it via the Dardanelles to the Mediterranean. The vertical thermohaline structure of the Black Sea is characterized by a pronounced density gradient between $125 \mathrm{~m}$ to $210 \mathrm{~m}$ (Brewer and Spencer, 1974). This gradient is caused by the surface inflow of freshwater from rivers and rain and the input of more saline Mediterranean water. Salinity in the deep water averages $22 \%$, in the surface water $18 \%$. The surface water has a mean summer temperature of $23^{\circ} \mathrm{C}$ and a winter temperature of $7^{\circ} \mathrm{C}$; the deep water has a temperature of $8-9^{\circ} \mathrm{C}$ all year round (Grasshoff, 1975). A thermocline exists at 10-15m depth in summer.

The surface water circulation in the Black Sea is controlled by a large cyclonic gyre which possibly converges south of the Crimean 
Peninsula (Neumann, 1942). Smaller eddies and countercurrents may form along the periphery, as documented by recent CZCS satellite imagery (chapter 2). The current velocity of the extensive surface currents decreases significantly with depth. Nevertheless, even at great depth the current velocity can be considerable. Current meter measurements reveal that velocities can be as high as $10-15 \mathrm{~m} / \mathrm{sec}$ at $700 \mathrm{~m}$ depth (Filippov, 1968). Bottom currents are generally absent as shown by bottom photographs of a benthic transition zone ("fluff" layer) above the sediment surface (Vine, 1974; Barnard and Fanning, 1976). This sediment fluff layer has an extremely low density and varies in thickness between 2 and $20 \mathrm{~cm}$ at the different sites (Barnard and Fanning, 1976).

The western Black Sea is dominated by a wide shelf of the Danube fan. The southern part of the western Black Sea and the entire eastern Black Sea are lined with an extremely narrow shelf of typically much less than $15 \mathrm{~km}$. The shelf break to the continental slope occurs at a depth of about $100 \mathrm{~m}$. Presently, the Black Sea is a giant catch basin for river discharge of half of Europe and part of Asia. About $55 \%$ of the suspended sediment load to the Black Sea comes from the Danube drainage system (western Black Sea), $29 \%$ from the Caucasian rivers (eastern Black Sea), $10 \%$ from the Anatolian rivers, and only $6 \%$ from all of the remaining Russian and Bulgarian rivers (Shimkus and Trimonis, 1974). 
The seasonal phytoplankton dynamics in the Black Sea is typical for a temperate marine basin. It is characterized by relatively high primary productivity, specifically in the region near the Danube delta (Finenko, 1967). Spatial variations in primary productions are caused by regional variability in nutrient supply. Nutrients are supplied most abundantly in areas around the mouths of the rivers and in areas of upwelling, i.e. in peripheral parts of the Black Sea and the convergence zone of the large gyre. There are two main maxima in primary production: a larger one in early spring from February to April, and one in late summer from August to September (Pyzik, 1968). A large amount of data on the biomass/biocoenosis of planktonic flora in the Black Sea has been accumulated by many Russian colleagues in the past. Nevertheless, as stated only recently by Sorokin (1982), one of the leading Russian authorities on the biology of the Black Sea, "reliable data on the annual primary production of this basin are still lacking because existing sampling has missed the main seasonal maximum of phytoplankton growth, late spring-early summer" (p. 269). Sorokin (1982) further explains that this fact is "possibly the result of the preference by planktonologists of taking samples largely during the good weather season" (p. 269), i.e. summer/fall.

Abundant data also exist about various lithogenic, biogenic, and chemogenic components in the Black Sea sediments. An extensive study of the mineralogy and petrology of the Black Sea sediments was carried out by Mïller and Stoffers (1974) and Trimonis (1974). Schrader (1978) and 
Jouse and Mukhina (1978) accomplished a comprehensive explanation of the thanatocoenosis of diatoms and silicoflagellates throughout the Late Neogene and Quaternary history of the Black Sea. Bukry et al. (1970) first recognized that the white laminae in the sediments were composed almost exclusively of coccoliths of the species Emiliania huxleyi. The geochemical distributions of major elements and trace metals in sediments were analyzed in great detail by Hirst (1974) and Volkov and Fomina (1974).

It is clear, as all the studies from the last few decades indicate, that the mid-water oxic/anoxic interface in the Black Sea water column became firmly established in the Holocene, and that it has been rising ever since (Deuser, 1974). A recent varve count on laminated basinal cores established an age of 5,100 years as the first arrival of euxinic sediments (Degens et al., 1978). By only about 2,800 B.P., the oxic/anoxic interface had risen to $470 \mathrm{~m}$. At present, the we11-mixed, oxygenated surface water extends to a depth of about $160 \mathrm{~m}$. The water colum beneath the interface is completely anaerobic to the basin floor with $\mathrm{H}_{2} \mathrm{~S}$-concentrations of about $400 \mu \mathrm{gat} / 1$ (Brewer and Spencer, 1974). At present, the Black Sea represents the largest and probably the best self-contained anaerobic environment on earth. 
Thesis research objective

Out of the massive set of data gathered over the past 100 years on particle generation and deposition of materials in the Black Sea, one critical area of knowledge is totally lacking, namely the spatial and temporal variability in the particulate flux in the present and past. High-resolution variability in particulate flux has been studied in recent years most successfully using sediment traps (e.g. Honjo, 1982, Honjo et al., 1982a; Honjo et al., 1982b; Honjo, 1984; Knauer et al., 1979; Dymond et al., 1981; Gardner et a1., 1983). Annua1 phytoplankton variability in recent laminated sediments was studied for example by Baumgartner et al. (1985).

The prime objective of my thesis research was to couple the annual material fluxes in the southwestern Black Sea (time-series sediment traps; joint program between the Dokuzeylül Universitesi, Izmir, Turkey, the Universität Hamburg, F.R. Germany, and the Woods Hole Oceanographic Institution) with its undisturbed varved sediments (cores). The focus of this comparison between core and trap data was to closely investigate temporal variability of the particle flux (seasonally and over the last 5,000 years), as we11 as particle sources and transport mechanisms in the western Black Sea. The thesis consists of three chapters, each of which addressing one important aspect in particle supply and dynamics in the Black Sea. The content and specific focus of these chapters are as follows: 
Figure 1: Location map of all the sites for all the samples used in this study, including the sediment trap sites BS and BSC (Izdar et al., 1984; Kempe, 1985; Honjo et a1., 1987a; Honjo et a1., 1987b) as well as the sites of the laminated cores 5, 18, and 35, collected during R/V CHAIN cruise \# 120-1 in 1975 (Degens et a1., 1980). 


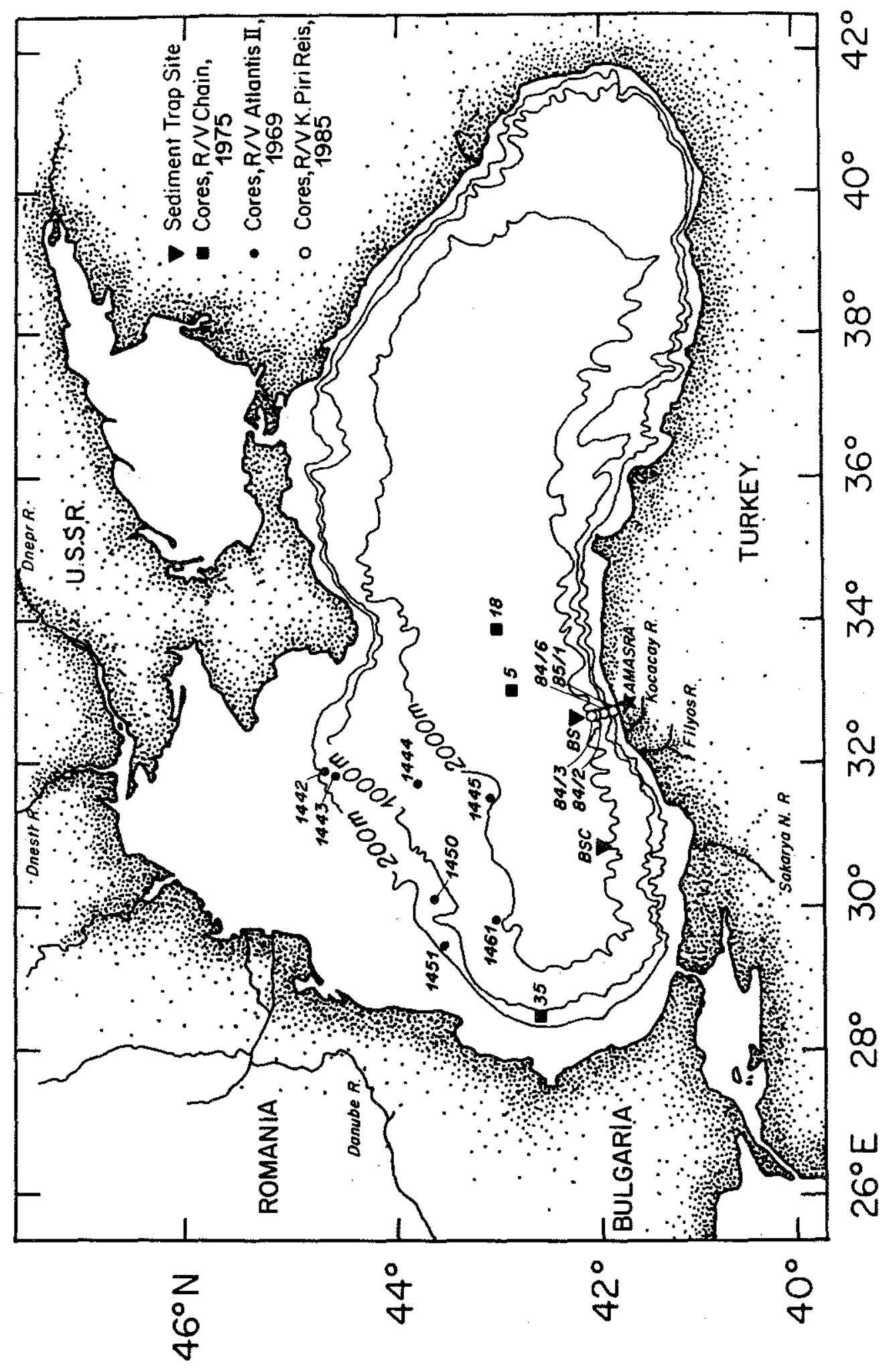


Chapter 1 is a summary of the present-day particle flux and the major flux components in the southwestern Black Sea (station BS, Fig. 1) over the $21 / 2$ year sampling period (1982-1985). Additional time-series data of wind stress near station BS and discharge of local Western Anatolian rivers, as well as satellite imagery were used for the analysis of the particle flux record. The interpretation of the results focused on seasonal variability in primary production, input of terrigenous particles by rivers, and resuspension of particles from the shelf.

Chapter 2 is an extension of the study on particle flux throughout the last 5,000 years of deposition (paleoflux) by investigating the laminated sediment record in detail. This study is based on three laminated cores from the western Black Sea, which were collected in 1975 by the R/V CHAIN (Degens et al., 1980; Fig. 1). Particle flux at the time of deposition in the water colum was recalculated from the paleoflux, and was then compared to the present-day particle flux in the southwestern Black Sea at station BS. Specifically, the focus of this chapter was to (1) to analyze the long-term variability of paleoflux over the last 5,000 years in the western Black Sea, (2) to analyze the regional variability of particle flux between the western Black Sea (cores) and the southwestern Black Sea (traps), and (3) to link the seasonal variability of the present-day particle flux to the season of deposition of individual black and white laminae. 
Chapter 3 is an analysis of the seasonal variability of the $\mathrm{Ti}$ and A1 flux as well as illite and montmorillonite flux in order to further investigate the seasonal variability in the terrigenous particle supply of rivers surrounding the western Black Sea. The Danube is the largest supplier of terrigenous matter to the Black Sea and therefore plays a vital role in the particle flux in the western Black Sea. Ti/A1 and illte/montmorillonite ratios were used to determine the relative input of terrigenous matter derived from the Danube versus the Western Anatolian rivers in the particle flux of the southwestern Black Sea.

Linking present-day particle flux with paleoflux, and linking seasonality in particle flux of traps with black and white laminae in cores, documents on one hand similarities in the processes of particle generation and transport mechanism in the western Black Sea, but on the other hand shows considerable differences in the relative importance of the individual processes in different regions of the Black Sea. This study further helps to unravel complexities in detailed sedimentation processes in anoxic paleooceans, such as those existing in the Cretaceous and the Precambrian. In addition, it offers a conceptual framework for the broad research effort of the refined understanding of the spatial and temporal variability in the particle flux of the present and past in the entire Black Sea; this effort will be carried out in 1988 as part of the R/V KNORR cruise to the Black Sea. 


\section{$-12-$}


$-13-$

Chapter 1

SEASONAL VARIABILITY IN THE PARTICLE FLUX

IN THE SOUTHWESTERN BLACK SEA 
Particle fluxes were measured continuously for two and a half years at approximately two-week intervals at a Black Sea station $40 \mathrm{~km}$ from shore by two sediment traps moored $250 \mathrm{~m}$ and 1,200 $\mathrm{m}$ below the surface.

Three factors controll quality and the quantity of particle flux at this station: 1) photosynthetic production of mineralized particles, 2) detrital input from Anatolian rivers, and 3) shelf sediments which were resuspended and transported offshore. The major component of the biogenic flux was coccoliths which were formed and settled during June to October. Characteristics of particles settled during this stage were similar to those of light-colored laminae in varved bottom sediments. Lithogenic particles settled in winter by river transport and storm-induced resuspension of shelf sediments. Dark laminae, rich in clay, appeared to be formed thus during winter. The sinking speed of particles during winter were estimated at about $125( \pm 60)$ meters per day, from observing the off-set of arrival times between traps. During summer the settling rate of particles was slower than in winter.

On an annual basis, the particle flux can be grouped into three distinct time periods: Phase I (June- October), characterized by a coccolithophorid bloom; Phase II (November to January), characterized by storm resuspension of mostly coccoliths from the shelf; and Phase III (February-May), characterized by river input of clays and a bloom of silicious organisms (diatoms and silicoflagellates). 


\subsection{INTRODUCTION}

The Black Sea represents the largest and most complete anoxic environment on earth. Nearly isolated from the influence of the world ocean, the Black Sea is nevertheless large enough to be controlled by many of the same laws of oceanography that govern the major oceans. Meanwhile, the Black Sea environment is most clearly characterized by the stratification of oxic and anoxic layers covering its entire area. The Black Sea is further unusual in having very narrow shelves along more than half of its margin, allowing for detrital sediment to be transported rapidly offshore. The Danube plays a major role in transporting detritus to the Black Sea, forming a huge shallow delta which occupies a significant part of its northwestern corner.

Because of absence of bioturbation, delicate laminae of sediment are genera1ly well preserved in the abyssal bottom sediment, as a result of the establishment of anoxic conditions in the water column 5,000 years ago (Degens at a1., 1980). Each black and white laminae pair is presumed to represent an annual sedimentation cycle (see section 2.3.3). Indeed, the Black Sea is one of the rare environments where flux and sediment can be coupled in a direct sense: the non-bioturbated sediments allow reconstruction of past oceanographic processes with the possible precision of annual events. An understanding of the geobiochemical and sedimentological processes in modern anoxic environments is thus crucial for detailed paleoceanography. 
Laminae of different colors were observed in the three most recent sedimentary units of the Black Sea (e.g. Ross and Degens, 1974). Murray (1900) first ascribed the white "amorphous" carbonate phases to inorganic precipitation. His conclusion was consistent with the observation by Androsov (1890) who found only few microscopic planktonic organisms in the fine carbonate muds. Not until electron microscopic studies of sediments, were the white bands recognized as almost exclusively composed of a single species of coccoliths (Bukry et a1., 1970). Uncertainty remained, however, regarding the nature of the black laminae. Dickman and Artuz (1978) suggested oxygen-induced seasonal mass mortality of photosynthetic bacteria and their subsequent sedimentation as one possible cause. In opposition to their idea, Degens and Stoffers (1980) argued that the supply of photosynthetic bacteria is constant whereas the black laminae represent seasonal events. This hypothesis was supported by Caraco and Honjo (1987) who found no detectable photosynthetic sulfur bacteria pigment in the material collected by sediment traps. These authors proposed instead that dark bands may form by absorption of dissolved iron, concentrated just below the $\mathrm{O}_{2} / \mathrm{H}_{2} \mathrm{~S}$-interface, onto sinking particles during winter storms. In order to fully understand the origins and sedimentary mechanisms of white and black laminae, we need to examine in detail settling particles prior to their arrival....at the... bottom. The seasonality and time-stratigraphic relationship of particles can be resolved by examination of settling particles which are sampled in 
sequence throughout the seasons.

The annual sequence of particle fluxes in the Black Sea was measured for the first time in a joint project between the Universität Hamburg, F.R. Germany, the Dokuzeylül Universitesi, Izmir, Turkey, and the Woods Hole Oceanographic Institution (Izdar et al., 1984; Degens et a1., 1984; Kempe, 1985; Honjo et a1., 1987a, Honjo et al., 1987b). Using automated, moored sediment traps (Honjo and Doherty, 1987), the vertical flux at a southern Black Sea station (Fig. 2) was collected at $250 \mathrm{~m}$ and $1,200 \mathrm{~m}$ continuous $1 \mathrm{y}$ at approximately 2-week intervals for a period of $21 / 2$ years (Table 1 ). Also, on-board the R/V Piri Reis, studies of the water column chemistry, suspended particles, and plankton succession were conducted twice a year in April and October of 1983, 1984, and in April only of 1985 (Degens et a1., 1984).

The main objective of this chapter is: (1) to examine the annual variability of the particle flux and its major components in the Southern Black Sea and (2) to identify the dominant mechanisms and processes which affect the supply of biogenic and lithogenic particles to the Black Sea. These results are significant in two ways. First, they enhance our understanding of major annual processes involved that link sediment supply (river detrital input and primary production) with sediment dispersa1 mechamisms in near-shore marine environments. Second, these results contribute significantly to the study of ancient sediments in anoxic environments for the reconstruction of seasonal and 
Figure 2: Detailed location map of the sediment trap mooring site BS in the Black Sea with bathymetric data. The mooring array was deployed continuously at this site from September 1982 to April 1985. The shortest distance to shore is approximately $40 \mathrm{~km}$. Note the narrow shelf and the steep continental slope near the trap site. 


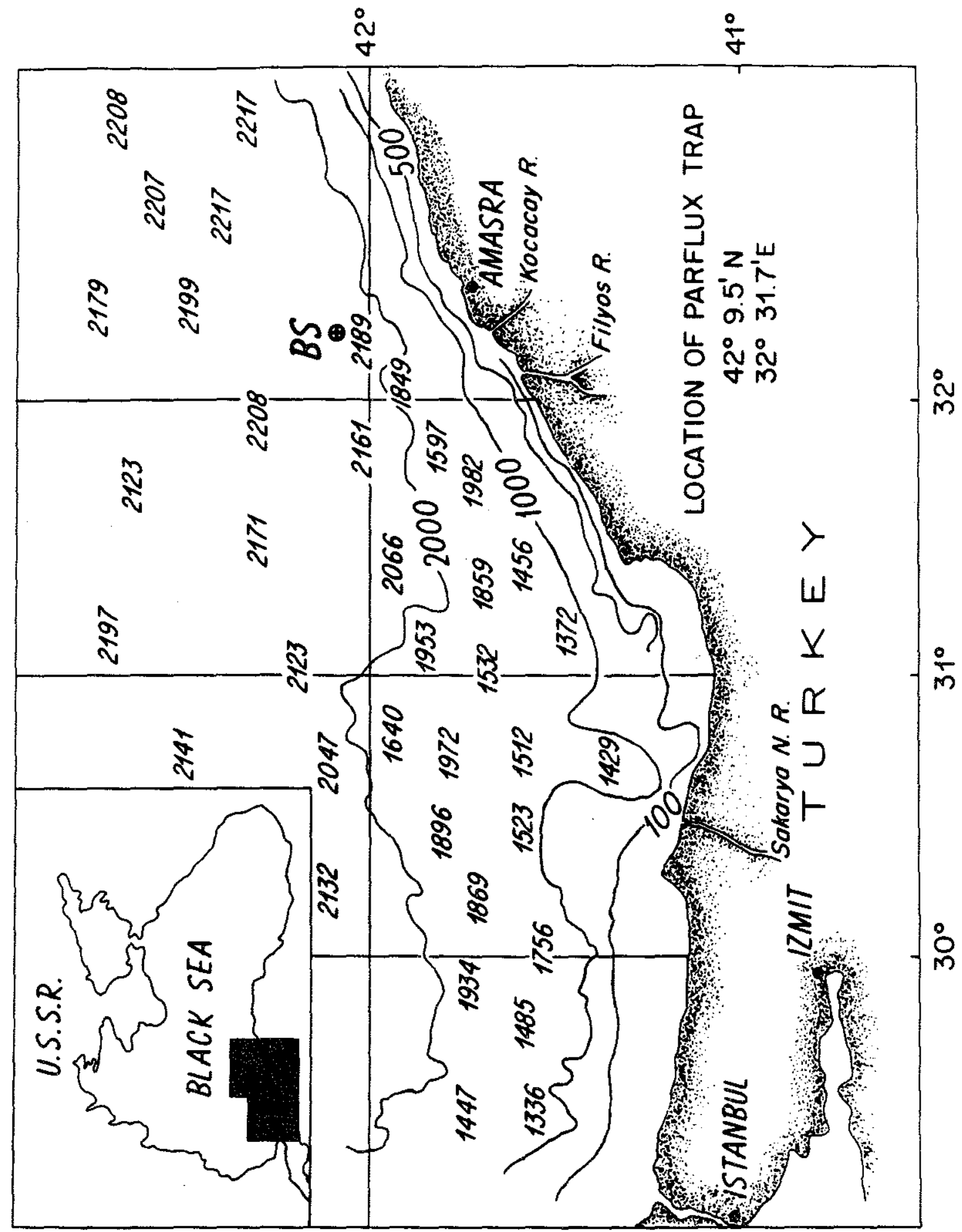


Figure 3: Schematic diagram of the sediment trap mooring array used in the deployment of two MARK $\mathrm{V}$ sediment traps at $250 \mathrm{~m}$ and 1,200 $m$ on the abyssal plain in the Black Sea at station BS (Honjo et a1., 1987a). 


\section{BLACK SEA MOORING SYSTEM}

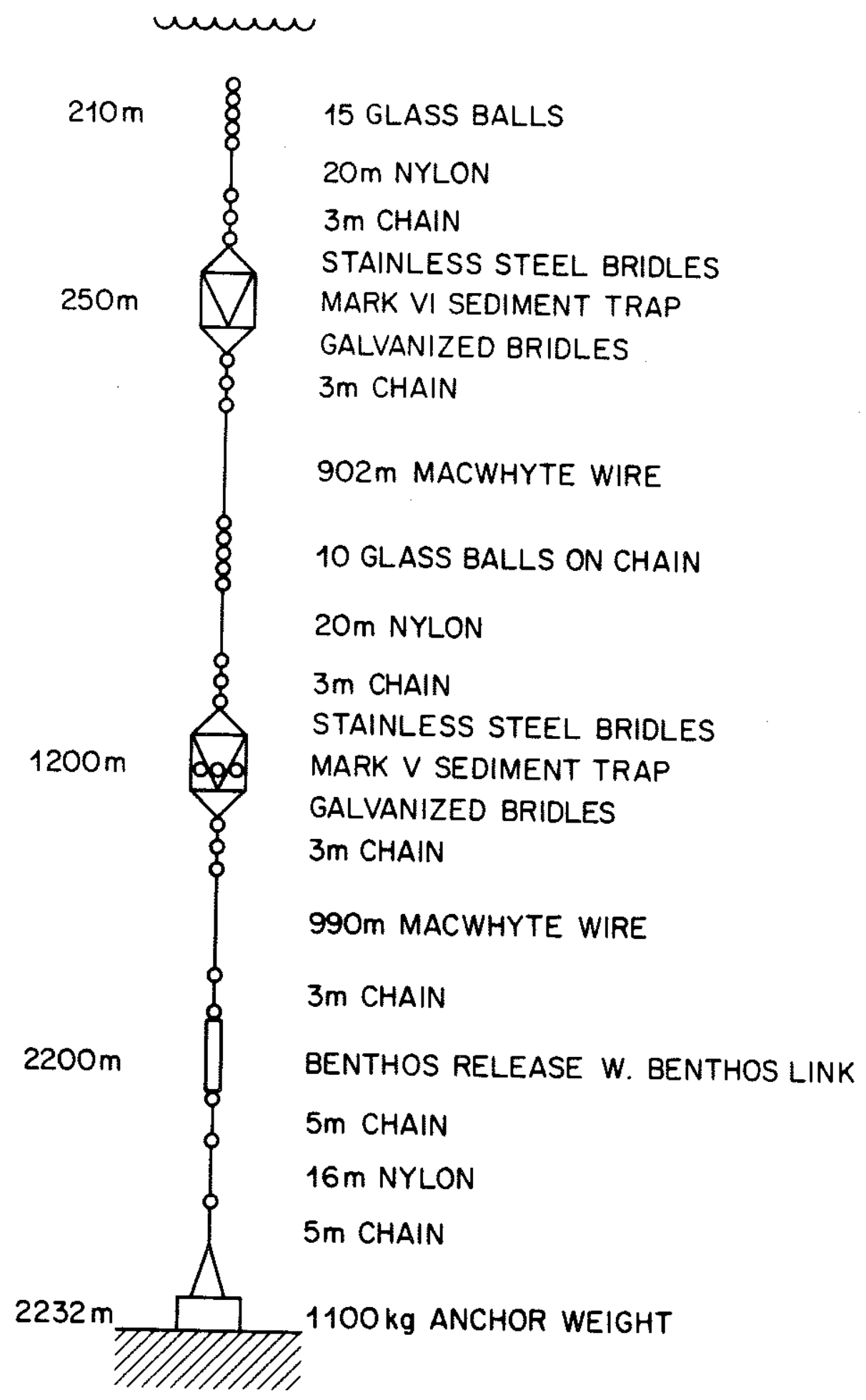


Table 1: Summary of deployment schedules of sediment trap mooring array at station BS, deployed by R/V Koca Piri Reis of the Dokuzeylül Universitesi of Izmir, Turkey, water depth, trap location in the water column, and quality of the samples for all sediment trap deployments during the PARFLuX project in the Black Sea. This project was carried out jointly by the Dokuzeyliil Universitesi, Izmir, the Universität Hamburg, F.R. Germany, and the Woods Hole Oceanographic Institution (Izdar et al., 1984; Degens et a1., 1984; Kempe, 1985; Honjo et al., 1987a; Honjo et a1., 1987b).

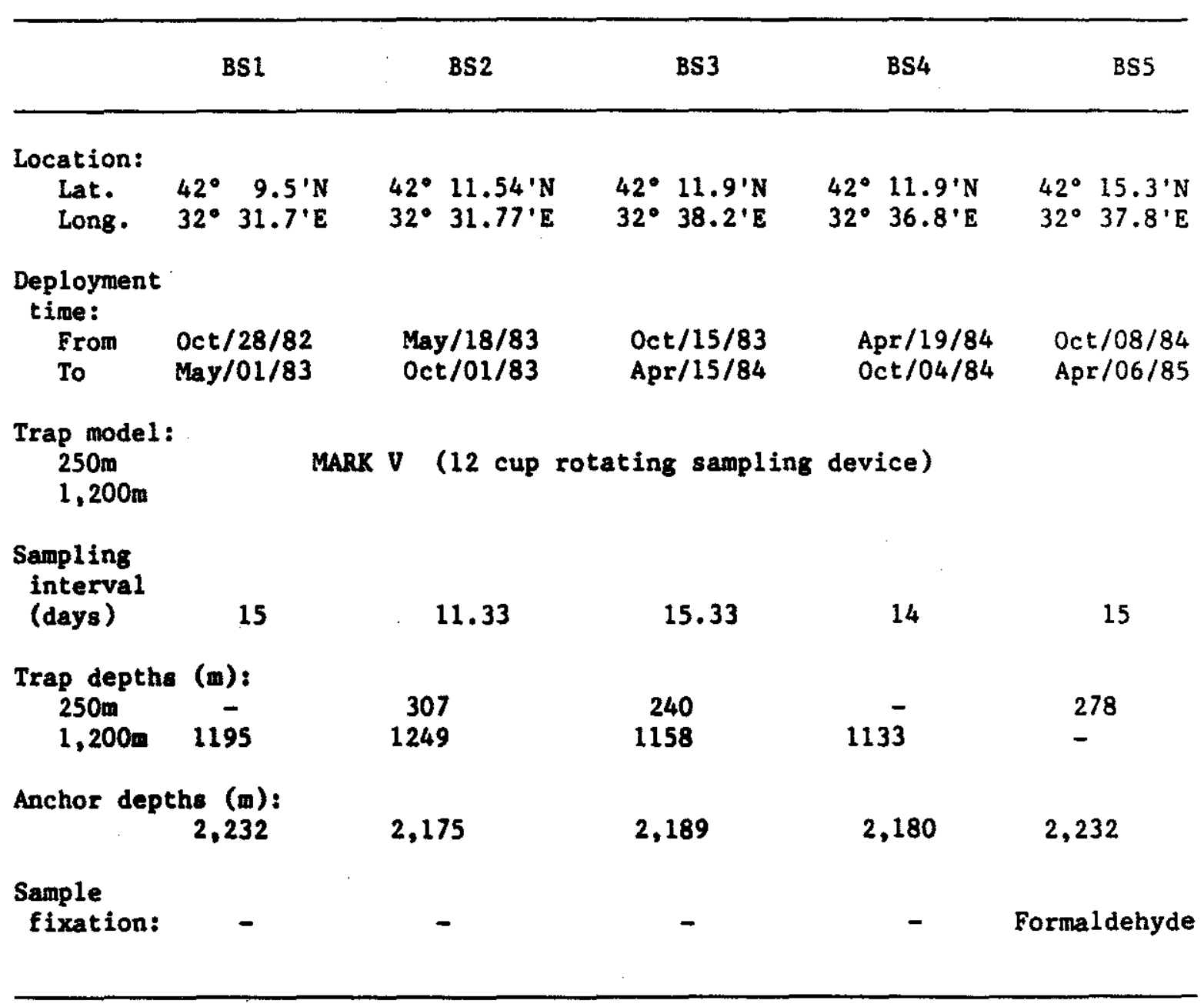


longer-term sedimentation patterns in respective paleooceans.

\subsection{METHODS}

\subsubsection{Particle flux}

The sediment trap mooring array was deployed between October 28 , 1982 and April 6, 1985 at station BS $\left(42^{\circ} 9.5^{\prime} \mathrm{N}, 32^{\circ} 31.7^{\prime} \mathrm{E}\right)$ with the R/V K. PIRI REIS of the Dokuzeylül Universitesi (Fig. 3; Table 1). Station BS was located about $40 \mathrm{~km}$ north of Amasra, on the southern Black Sea coast. The location of the trap mooring array changed by only about half a kilometer during the entire five series of deployments.

The coastal topography in the Amasra area is mainly formed by east-west striking strike-slip faults. Thus the shoreline is bordered by rugged cliffs and a narrow marine shelf. The continental slope near Amasra is particularly steep. Between $100 \mathrm{~m}$ and $2,000 \mathrm{~m}$ the average slope angle is about $6^{\circ}$ (Ross et a1., 1974). The transition between the continental slope and the relatively flat Euxine Abyssal Plain (depth: about 2,200 m) is abrupt (Fig. 2). The sediment traps were moored $15 \mathrm{~km}$ from the base of the continental slope at a water depth of approximately 2,200 m (Tąble 1).

Station BS was relatively close to the Anatolian shoreline and near 
the flank of a steep slope. Therefore, detrital sedimentation at this station was different from that in the far off-shore central plain. However, the water column chemistry at this station was identical to that observed at a number of stations in the central area, described by Brewer and Spencer (1974). The depth of the anaerobic interface was approximately 175 meters and stratification was stable during the bi-annual geochemical profiles of the water column made in May and October, 1982 to 1985 (Tab1e 1; Degens et al., 1984; Kempe, 1985).

Mooring array and samples were recovered every six months, and an array was redeployed a few days after recovery, immediately after econditioning (Honjo et a1., 1987a). Two time-series sediment traps, of the type Mark 5 (Honjo and Doherty, 1987) each with a $1.2 \mathrm{~m}^{2}$ opening, were moored in a vertical array at about $250 \mathrm{~m}$ and $1,200 \mathrm{~m}$ (see Table 1 for precise deployment depths). Sampling intervals varied between 11.33 and 15.33 days (Table 1 ). Sampling intervals in the $250 \mathrm{~m}$ and $1,200 \mathrm{~m}$ traps were identical and opening/closing times were synchronized between the two depths.

Time-series samples were collected from May 18, 1983 to April 15, 1984 and from October 8, 1984 to April 6, 1985 in the $250 \mathrm{~m}$ trap, and from October 28, 1982 to October 4, 1984 in the 1,200 $\mathrm{m}$ trap (Table 1). Samples were unpoisoned except for samples in the $250 \mathrm{~m}$ trap from October 8, 1984 to April 6, 1985, which were poisoned with $5 \%$ formaldehyde (Honjo et a1., 1987a). High $\mathrm{pH}$ values of the three samples 
between March 12, 1982 and May 1, 1982 (deployment BS1, \#10-12) indicate that the water in the sampling cups was exchanged with surface water (Ittekkot et al., 1984); results from these three samples should be used with caution.

Each sample in its container was sealed under nitrogen atmosphere and refrigerated immediately upon recovery on board ship. Upon arrival in the shore laboratory, samples were first sieved through a Nylon mesh with $1 \mathrm{~mm}$ openings (Fig. 4). Material which passed through the mesh was then split into 4 equal aliquots using a precision wet splitter (Honjo, 1980).

One $1 / 16$ aliquot of the $<1 \mathrm{~mm}$ fraction was filtered with a preweighed 0.45 um Nuclepore $(R)$ filter and rinsed with distilled water three times. After drying for 24 hours at $50^{\circ} \mathrm{C}$ the dry weight was determined from which the total flux for the $<1 \mathrm{~mm}$ fraction could be calculated. For determination of total flux and major flux components (described below) for the $>1 \mathrm{~mm}$ fraction, the same respective procedures were carried out as for the $<1 \mathrm{~mm}$ fraction. To determine carbonate flux, the dried sample was immersed in $10 \%$ acetic acid and ultrasonically dispersed. After 24 hours the sample was filtered, rinsed with distilled water, dried, and reweighed. The carbonate flux was: computed from the weight loss. The organic carbon, flux was determined by analyzing about $5 \mathrm{mg}$ of the decalcified sample with a Hewlett-Packard ${ }^{(R)}$ CHN Analyzer. 
Figure 4: Schematic flow-diagram of the laboratory processing and analysis of the Black Sea sediment trap samples (Honjo et al., 1987a). 


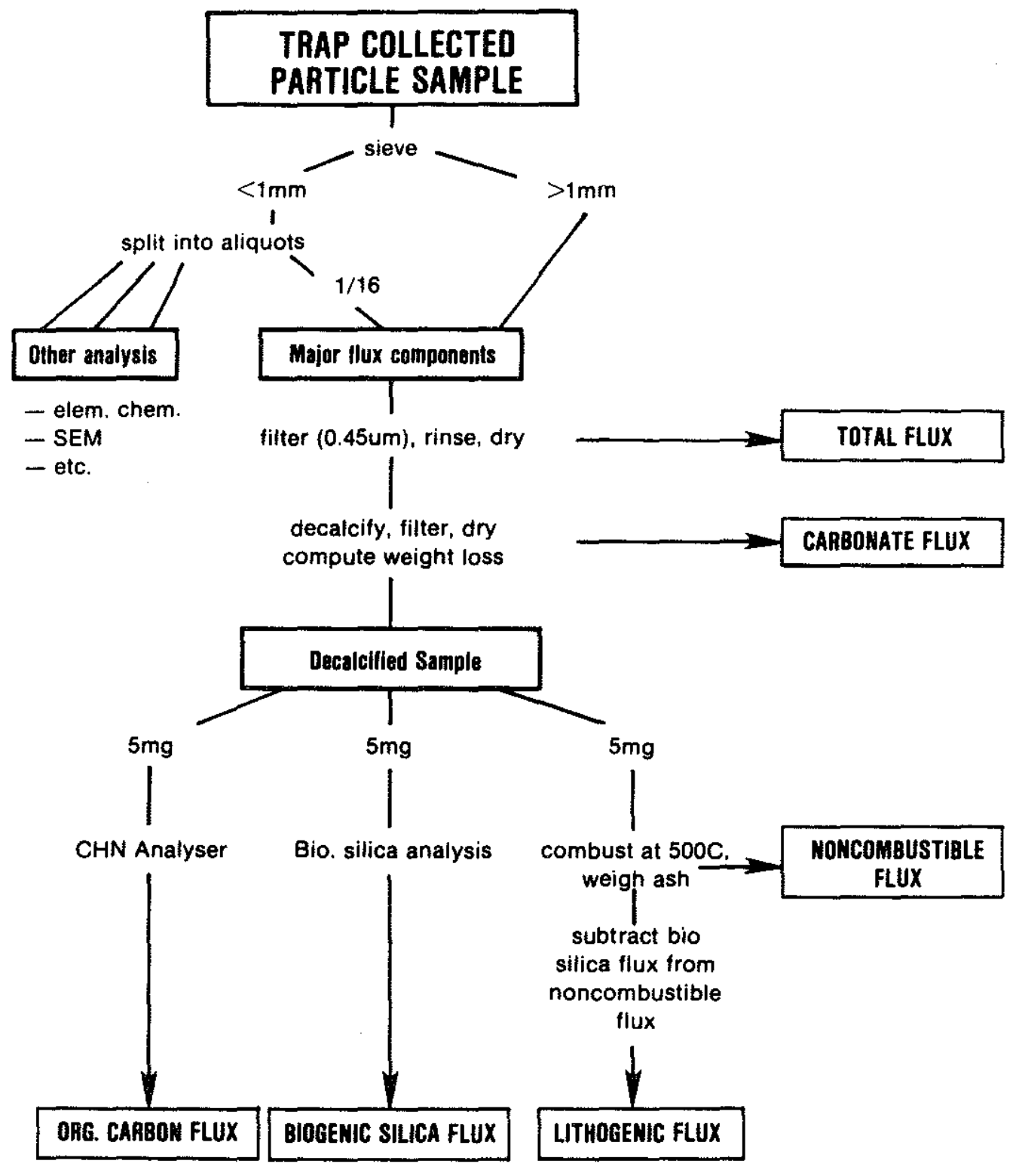


The biogenic silica flux was obtained from about $5 \mathrm{mg}$ of decalcified sample material using a method modified after Eggiman et al. (1980) and Strickland and Parsons (1968). Eggiman et a1. (1980) found that sediments with a biogenic silica/clay ratio larger than 1.0 can be analyzed by a single leach with $2 \mathrm{M} \quad \mathrm{Na}_{2} \mathrm{CO}_{3}$ solution without correction for silica that also had been leached from clays. Determination of reactive silicate depends on the production of a silicomolybdate complex forming between silica, leached by $\mathrm{Na}_{2} \mathrm{CO}_{3}$ into solution, and ammonium-molybdate which was added subsequently. A reducing solution containing metol and oxalic acid was then added, which reduced the silicomolybdate complex to give a blue reduction compound (Strickland and Parsons, 1968). The absorbance of this compound was measured with a spectrophotometer to yield a ppm value of biogenic silica in the sample, from which the biogenic silica flux subsequently was computed.

The lithogenic flux was determined indirectly. About $5 \mathrm{mg}$ of decalcified sample was combusted at $500^{\circ} \mathrm{C}$ in a muffle furnace to remove organic material. From the weight of the remaining material (ash) the noncombustible flux was determined. The lithogenic flux was then computed by subtracting the biogenic silica flux from the noncombustible flux, under the assumption that the noncombustible flux was a sum of biogenic silica and terrigenous detritus (clay, quartz, and feldspar with minor igneous components). 


\subsubsection{Wind stress}

Wind stress was calculated after Amorocho and DeVries (1980, 1981) from three daily measurements of wind speed and direction $10 \mathrm{~m}$ above sea level at Amasra, Turkey, $41^{\circ} 45^{\prime} \mathrm{N}, 32^{\circ} 23^{\prime} \mathrm{E}$. Continuous data were available from April 1982 to March 1985.

As a first order approximation of the forces excerted onto the water surface, the wind stress is derived from the wind speed vectors. It is common1y expressed by

$$
\Theta_{0}=C_{d} \rho_{a} U^{2}
$$

where $\Theta_{0}$ is the wind stress, $U$ the surface wind velocity, generally measured at $10 \mathrm{~m}$ above the ocean surface, $\rho_{a}$ the mass density of air, and $C_{d}$ the dimensionless drag coefficient.

The drag coefficient $C_{d}$ is a function of parameters (such as Reynolds, Froude, and Richardson numbers) that involve the wind velocity $U$ at $10 \mathrm{~m}$ elevation, the vertical stability of the atmospheric boundary layer, and the aerodynamic roughness of the surface over which the wind is blowing (Sethuraman and Raynor, 1975). The parameters may further be influenced to some extent by wave height, wind fetch, and water depth 
(Wilson, 1960). One of the most recent summaries of data from a variety of sources was presented by Amorocho and DeVries (1980, 1981), who concluded that $C_{d}$ stays constant for low wind speeds, at which waves don't break. After the onset of breakers, to the condition of $f u 11$ breaker (at $7<U_{10}<20 \mathrm{~m} / \mathrm{sec}$ ), $C_{d}$ increases nonlinearly with $U$. For winds that are stronger than necessary for full breaker development, $C_{d}$ varies again linearly with $U$. Amorocho and DeVries (1981) summarized their findings in the equation

$$
C_{d}=(0.00121 \pm 0.00029)\left[1+\exp \left(-\frac{U_{10}-12.5}{1.56}\right)\right]^{-1}+0.00104
$$

which was used for the subsequent wind stress results. Raw wind speed data $\left(U_{1 \text { and }}\right)$ were corrected in order to compensate for the lower coastal wind speeds over land then over water using the relationship developed by Hsu (1981):

$$
\mathrm{U}_{\text {sea }}=3\left(\mathrm{U}_{\mathrm{land}}^{2 / 3}\right)
$$

\subsubsection{River discharge}

River discharge data from October 1979 to September 1982 for the Kocacay and the Sakarya Nehri were obtained from the Hydrographic Institute of Turkey, Ankara (unpub1. data). These data represent monthly averages of daily measurements. Continuous meteorological data 
from April 1982 to March 1985 also were made available by the Hydrographic Institute of Turkey, Ankara (unpub1. data).

\subsection{RESULTS}

\subsubsection{Seasonality and cyclicity of sedimentary components}

Three distinct phases can be distinguished in the annual regime of particle fluxes in the Black Sea (Fig. 5). The phases were determined from time-series data of particle flux composition, wind stress, and river input; conclusions about temporal variability, particle sources, and transport mechanisms drawn from these data were characteristically different for each phase. The phases prevail from June to October (Phase I), November to January (Phase II), and February to May (Phase III), with a variation of a few weeks on either side. These phases are repeated annually despite variations in the absolute flux. For reasons of simplicity the analytical results will be discussed in this study with respect to these three phases.

During the two and a half year time deployment, the particle flux in the Black Sea varied significantly within each phase, in the $250 \mathrm{~m}$ as we11 as in the 1,200 $\mathrm{m}$ deep trap. Typically, the total flux was larger in the $1,200 \mathrm{~m}$ trap than in the $250 \mathrm{~m}$ trap, with the exception of Phase II between 1983 and 1984. The largest flux occurred during this phase 
between Nov 14 and 30,1983 with $485 \mathrm{mg} \mathrm{m}^{-2}$ day $^{-1}$.

Considerable differences in total flux exist between $250 \mathrm{~m}$ and $1,200 \mathrm{~m}$ traps for any given individual sampling interval. The largest difference occurs in spring (Phase III). In Phases $I$ and II the difference between the two traps is more consistent. Differences between the two traps indicate the significance of lateral transport and patchiness. Nevertheless, the relative composition of the major chemical and biological components within each sample cup was similar. Therefore, the flux of the major particulate components from both traps will be discussed simultaneously below.

The carbonate flux clearly was largest in Phase II, with an average contribution to the total flux of $37 \%$ in the $250 \mathrm{~m}$ trap and $47 \%$ in the $1,200 \mathrm{~m}$ trap. Contribution of carbonate was relatively small in Phases I (23\% in both traps) and III (21\% and $16 \%$ in the $250 \mathrm{~m}$ and $1,200 \mathrm{~m}$ traps, respectively). On the other hand, the flux of biogenic silica was largest in Phase III, reaching $21 \%$ of the total flux in the $1,200 \mathrm{~m}$ trap. In Phase III in 1983 this peak in the $1,200 \mathrm{~m}$ trap extended into the subsequent Phase I, 1983. In the $250 \mathrm{~m}$ trap the maximum content of biogenic silica during Phase III was not nearly as high: only $5.8 \%$, which may have been caused by more intense dissolution in the $250 \mathrm{~m}$ trap due to higher undersaturation of silica at the shallower water depth. In Phases I and II the silica concentration in both traps was around 3 and $5 \%$. The organic carbon flux was largest in Phase I, reaching 
Figure 5: Time-series transition of total and major component fluxes compared between the $250 \mathrm{~m}$ and $1,200 \mathrm{~m}$ traps over the deployment period (October 28, 1982 to Apri1 5, 1985). 


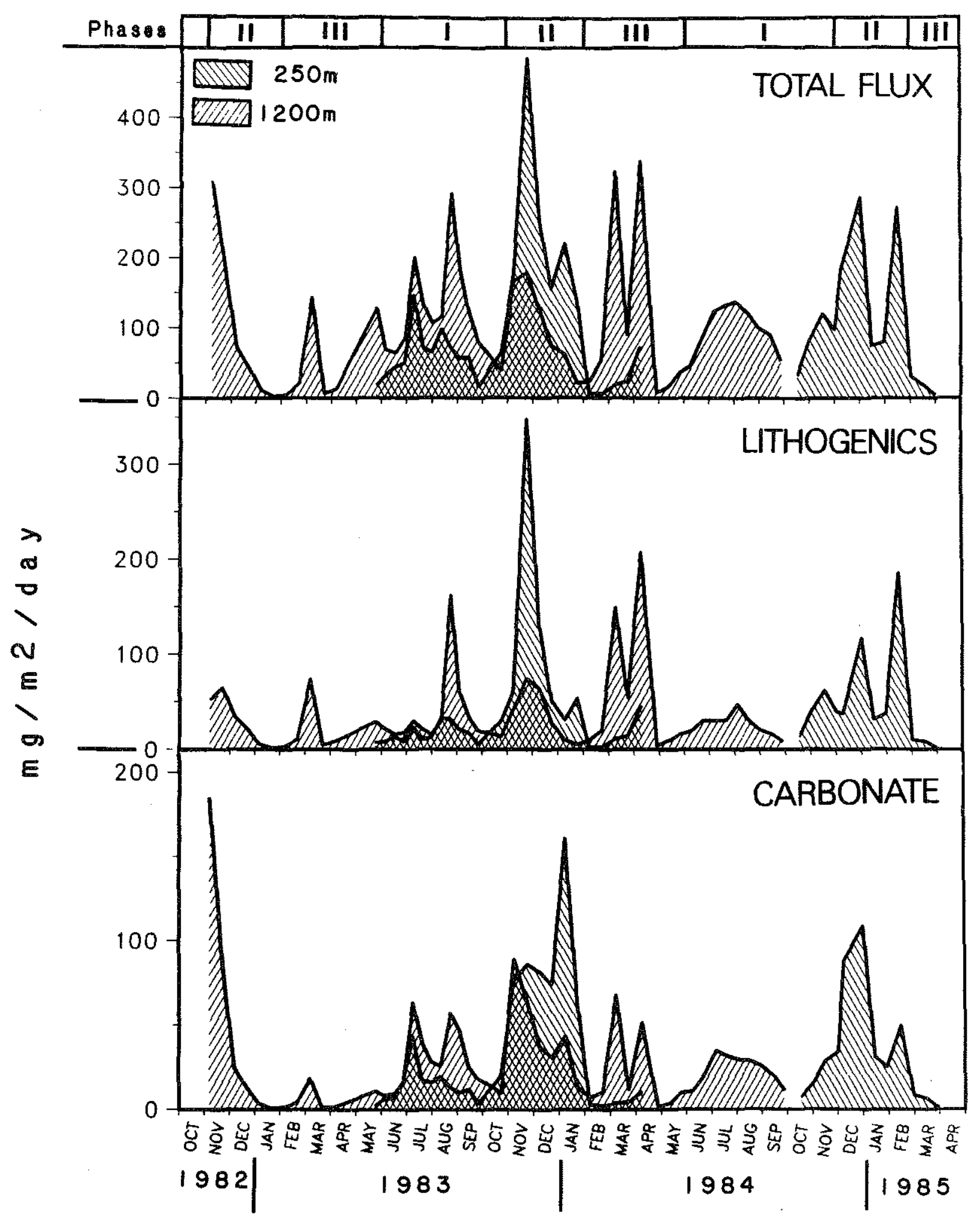




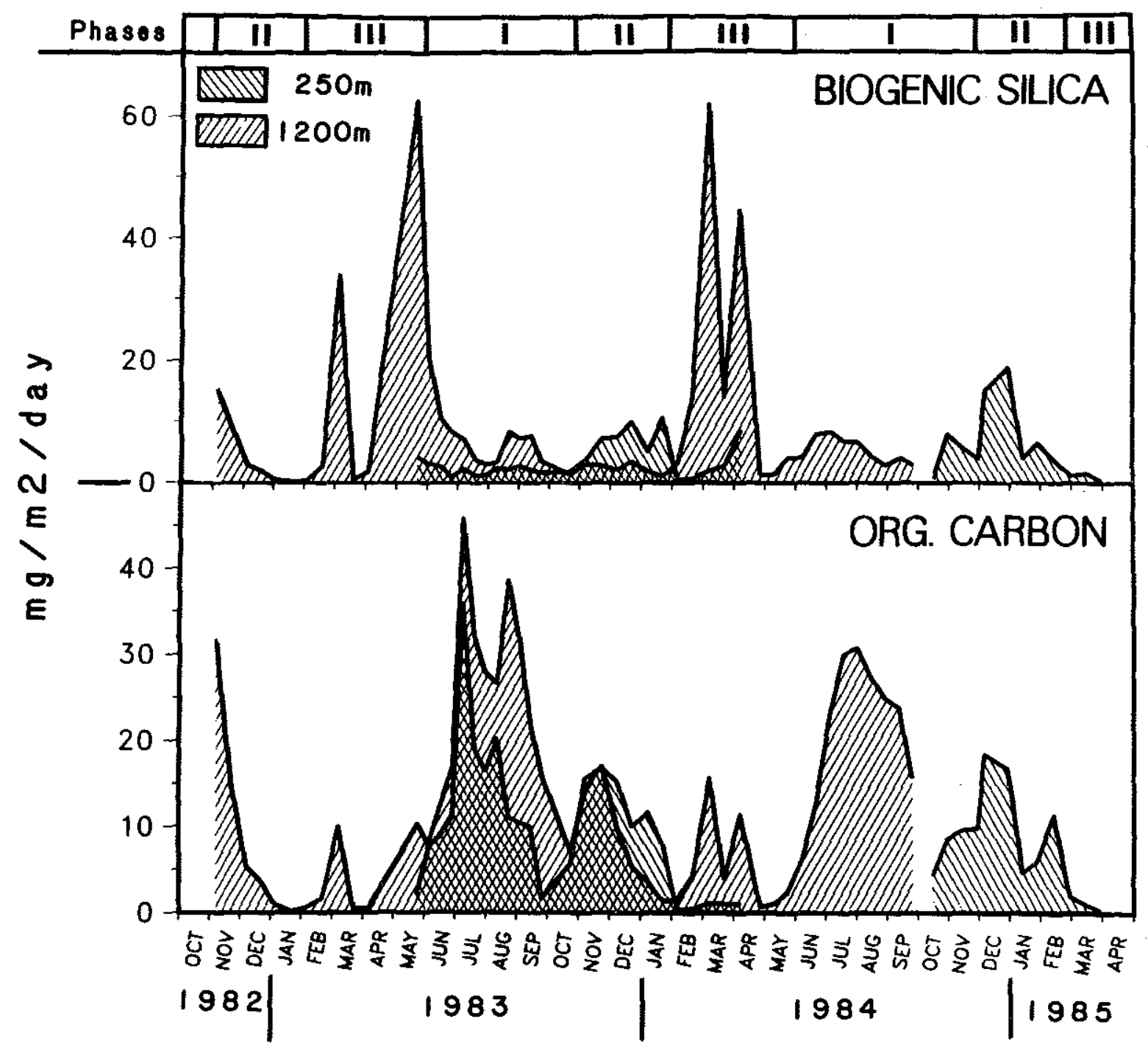


values of over $40 \mathrm{mg} \mathrm{m}^{-2}$ day $^{-1}$, and significantly lower values of only up to $16 \mathrm{mg} \mathrm{m}^{-2} \mathrm{day}^{-1}$ in Phases II and III (with the exception of sample $\mathrm{BS} 1$, 非1, 1,200 $\mathrm{m}$ trap). The organic carbon flux was about 20 $\%$ of the total flux for Phase I in both traps and between $5 \%$ and $8 \%$ for Phases II and III.

The lithogenic flux was largest in Phases II and III, reaching up to $346 \mathrm{mg} \mathrm{m}^{-2} \mathrm{day}^{-1}$ in the $250 \mathrm{~m}$ trap. Periods of high lithogenic flux typically occurred as sharp isolated peaks. The most pronounced peak was observed in the $250 \mathrm{~m}$ trap in the period between November 14 and 30, 1983. Throughout Phase I, the lithogenic flux was comparatively sma11; it was less than $50 \mathrm{mg} \mathrm{m}^{-2}$ day $^{-1}$ except for the peak between August 16 and 28,1983 , when the flux reached $160 \mathrm{mg} \mathrm{m}^{-2}$ day $^{-1}$.

\subsubsection{River discharge}

The solid discharge from rivers of the Turkish coast, which contribute an annual total 1iquid discharge of $25 \mathrm{~km}^{3}$ into the Black Sea, was estimated by Bol'shakov (1970) as $17 \times 10^{6}$ tons. Given the cyclonic surface water circulation in the Black Sea (Neumann, 1942), rivers flowing into the Black Sea from west of Amasra were suspected of supplying detritus to the BS mooring site. Relevant rivers are the Sakarya Nehri, Filyos, and the Kocacay (Fig. 2). Average annual river discharge of the Sakarya Nehri between October 1979 and September 1982 
was $7.17 \mathrm{~km}^{3}$ (drainage area: $55,322 \mathrm{~km}^{2}$ ), and $0.90 \mathrm{~km}^{3}$ for the Kocacay (drainage area: $1,342 \mathrm{~km}^{2}$ ) (Hydrographic Institute of Turkey, Ankara, unpub1. data). No information was available at present for the Filyos; its present annual discharge is estimated with $4-6 \mathrm{~km}^{3}$. Given a similar topography of the drainage area of these rivers and assuming a similar precipitation pattern, my estimates of the annual solid sediment loads of the Sakarya Nehri and the Kocacay are about $5 \times 10^{6}$ tons and $0.6 \times 10^{6}$ tons, respectively, as extrapolated from total solid and liquid loads for the Anatolian rivers by Shimkus and Trimonis (1974).

River discharge in both rivers increased in December and decreased rapidy in April to lower summer and fall discharge (Fig. 6a). Discharge peaks of the Sakarya Nehri were broader and offset by a few weeks from the Kocacay because of its larger drainage area and thus longer transport time of the water. The months of higher discharge in summer in the Kocacay in July 1981 and August 1982 were reflected in the Sakarya Nehri with discharge peaks in August 1981 and September 1982, respectively. The Filyos can be expected to have the same discharge pattern as those rivers since its drainage area is also in the northern Anatolian mountains and is located between drainage areas of the Kocacay and Sakarya Nehri. Average monthly water discharge of the Sakarya Nehri increased from $0.42 \mathrm{~km}^{3}$ in Phase $I$, to $0.66 \mathrm{~km}^{3}$ in Phase II, and $0.90 \mathrm{~km}^{3}$ in Phase III (Fig. 6a; Table 2). Average monthly water discharge of the Kocacay increased from $0.027 \mathrm{~km}^{3}$ in Phase $I$, to 0.125 $\mathrm{km}^{3}$ in Phase II, and $0.123 \mathrm{~km}^{3}$ in Phase III. The annual 
Figure 6: (a) Monthly river discharge of the Western Anatolian rivers Kocacay and Sakarya Nehri from records between October 1979 and September 1982 (Hydrograph. Inst. of Ankara, Turkey).

(b) Average monthly river discharge of the Danube from a month1y record between 1921 and 1964 (UNESCO, 1978). 


\section{River discharge - W-Anatolian rivers}

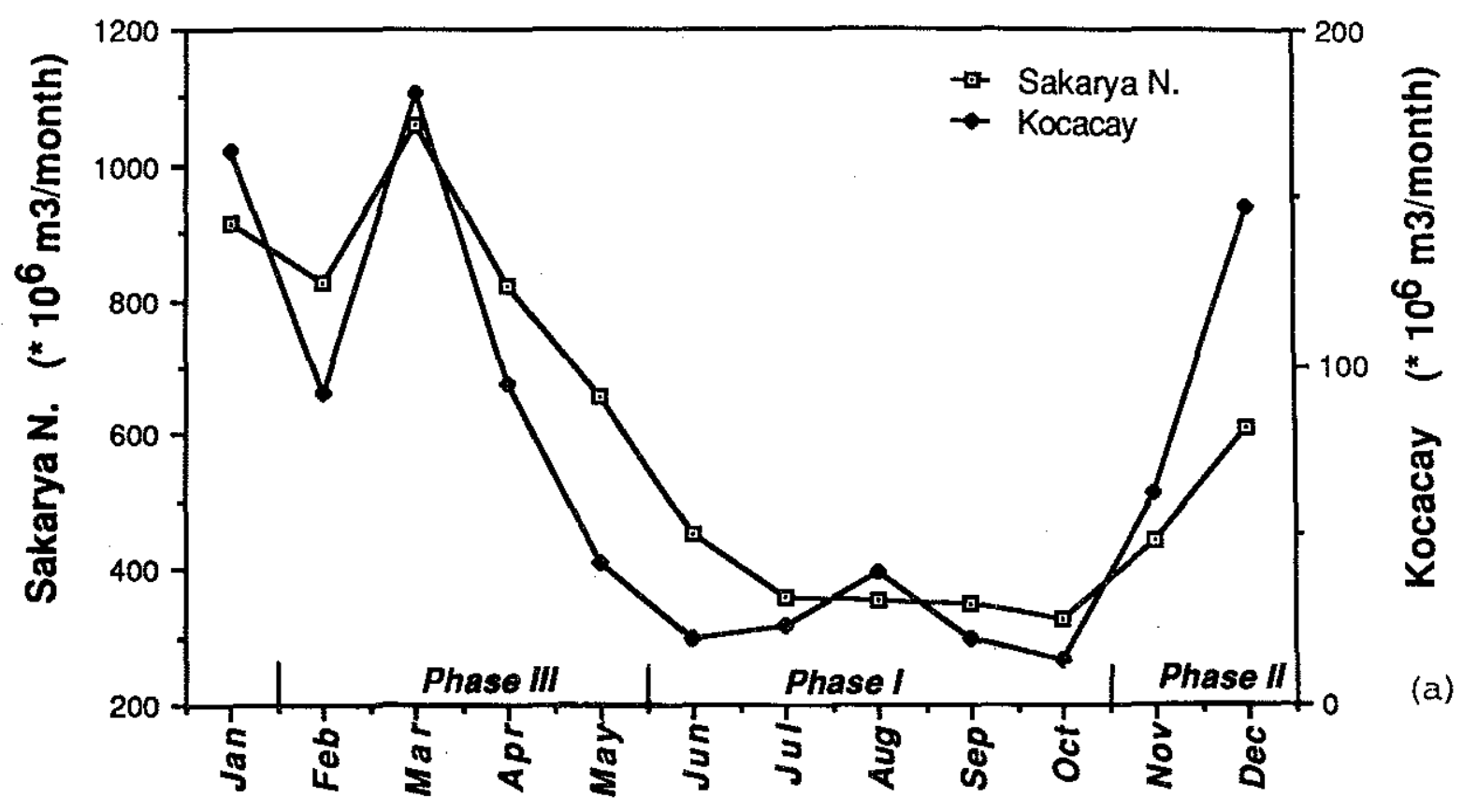

DANUBE DISCHARGE 1921-1964

Monthly Average

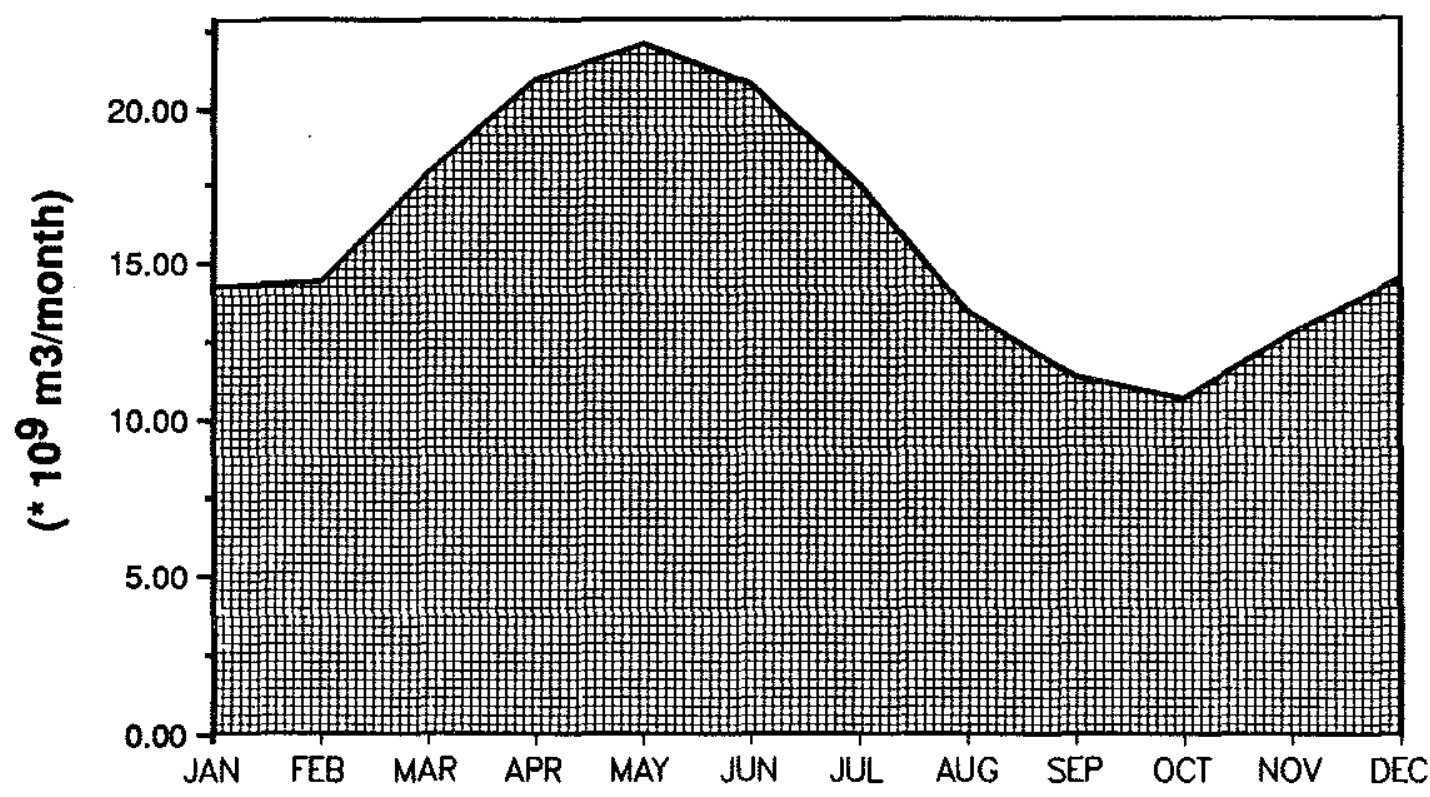

(b) 
Table 2 (a) Mean values for the $\mathrm{C}_{\circ g} /\left(\mathrm{CaCO}_{3}+\mathrm{Si}_{\mathrm{biog}}\right)$ ratio, the distribution of biogenic silica versus carbonate, and the distribution of lithogenics and non-lithogenics for the three phases averaged for the entire $21 / 2$ year-1ong deployment.

(b) Mean values of river discharge for the northern Anatolian rivers Sakarya Nehri and Kocacay (Fig. 1). Mean values are calculated from monthly river discharge between October 1979 to September 1982 (Hydrographic Institute of Turkey, Ankara, unpubl. data).

(a)

\begin{tabular}{|c|c|c|c|c|c|c|}
\hline \multirow{2}{*}{$\begin{array}{l}\text { TRAPS } \\
\text { PHASES }\end{array}$} & \multicolumn{3}{|c|}{$250 \mathrm{~m}$} & \multicolumn{3}{|c|}{$1,200 \mathrm{~m}$} \\
\hline & I & II & III & I & II & II I \\
\hline $\mathrm{Corg} /\left(\mathrm{CaCO}_{3}+\mathrm{Si}_{b+\circ}\right)$ & 0.76 & 0.19 & 0.15 & 0.73 & 0.18 & 0.37 \\
\hline \%Carbonate in $\left(\mathrm{CaCO}_{3}+\mathrm{Si}_{b} \mathrm{i}_{\circ g}\right)$ & 89.06 & 89.60 & 87.45 & 81.00 & 93.24 & 44.20 \\
\hline GLith. in (1ith.+ nonlith.) & 27.0 & 43.5 & 59.0 & 27.4 & 31.2 & 49.0 \\
\hline
\end{tabular}

(b)

PHASES I II III

\begin{tabular}{llll} 
Sakarya Nehri & 0.42 & 0.66 & 0.90 \\
Kocacay & 0.027 & 0.125 & 0.123 \\
\hline
\end{tabular}


distribution of high discharge was bimodal in both rivers.

Comparison between daily precipitation measurements at the weather station in Amasra (Hydrographic Institute of Turkey, Ankara, unpubl. data) and the river discharge pattern (Fig. 6a) indicated that the peak in January was a result of high precipitation whereas the peak in March appear to be caused by melt water from the Anatolian mountains. A third sma11 peak was observed in 1982 in August which correlated with high rainfall during this time. During summer, rainfall was generally small except for the time period between the end of July and the middle of August, 1983, where the high rainfall possibly resulted in relatively large lithogenic flux between August 16 and 28 that year, specifically, in the $1,200 \mathrm{~m}$ trap. In 1984 no summer rainfall peaks which were equivalent to the 1983 peaks were recorded. At the same time the lithogenic flux was comparatively small during this time period.

A considerable fraction of particulate river input appears to settle on the shelf. Particle deposition over the shelf is illustrated by higher spectral reflectance of the sediment plumes close to the mouths of the rivers Filyos and Kocacay as seen on the LANDSAT image from April 27, 1984 (Fig. 7). The plume of the Filyos extends offshelf for about $40 \mathrm{~km}$ before it disappears from the surface. 
Figure 7: Section of LANDSAT 5 image, Band 2, from April 27, 1984, showing the plume of suspended particles at the mouths of the rivers Filyos (large) and Kocacay (small) relative to the trap station BS. The plume of the Filyos extends about $40 \mathrm{~km}$ into the Black Sea. Higher spectral reflectance of the plumes nearshore indicates rapid settling of suspended material upon entry into the Black Sea. 


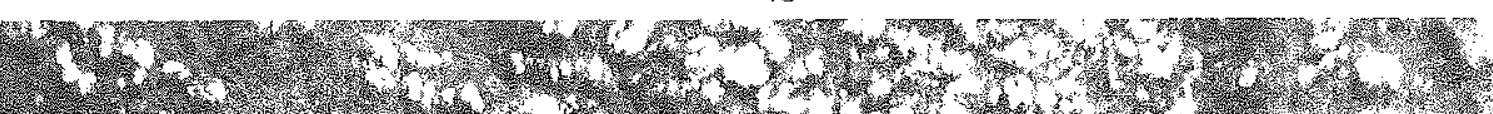

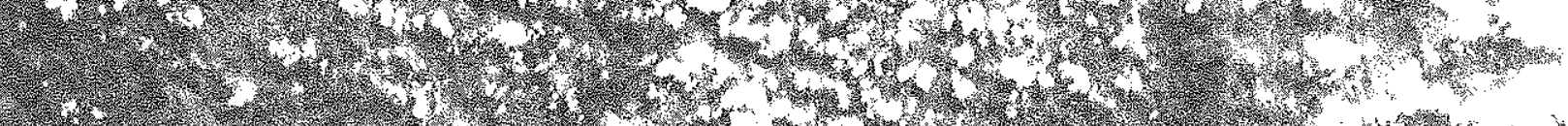

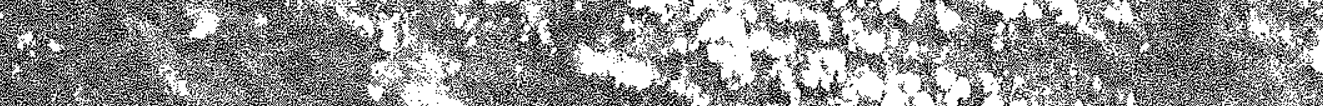

1.6.

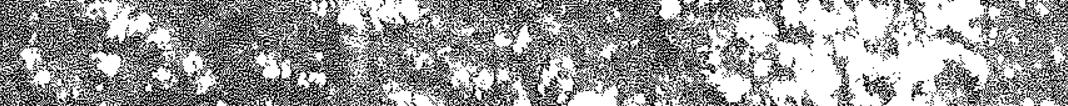

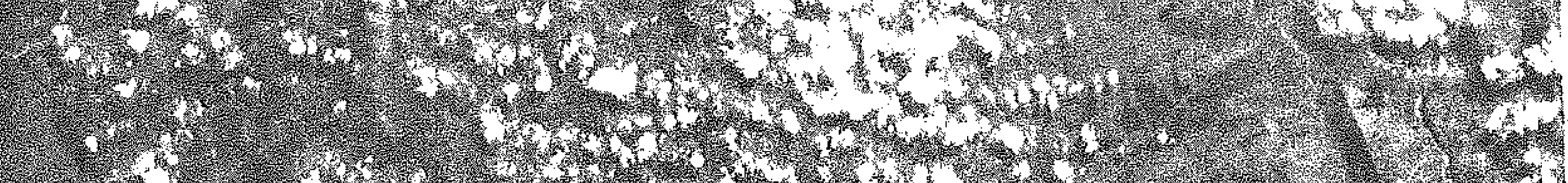

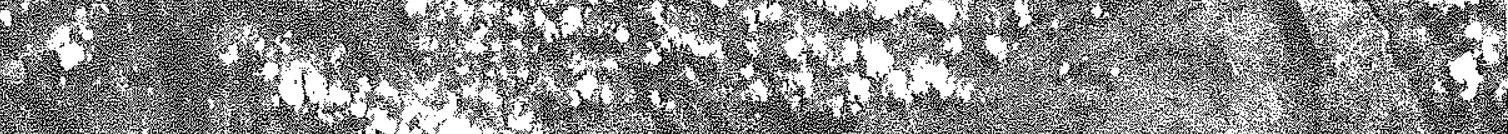

7.

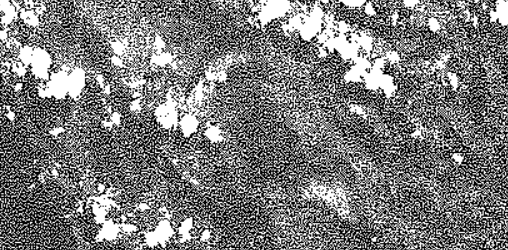

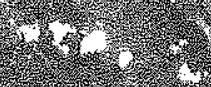

the 6

t.

1.7.

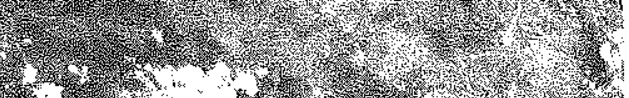

3
3

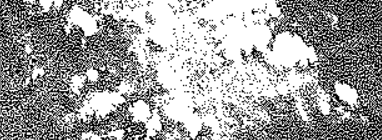
2.7.7.7.

r.

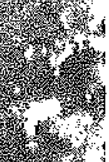

tit

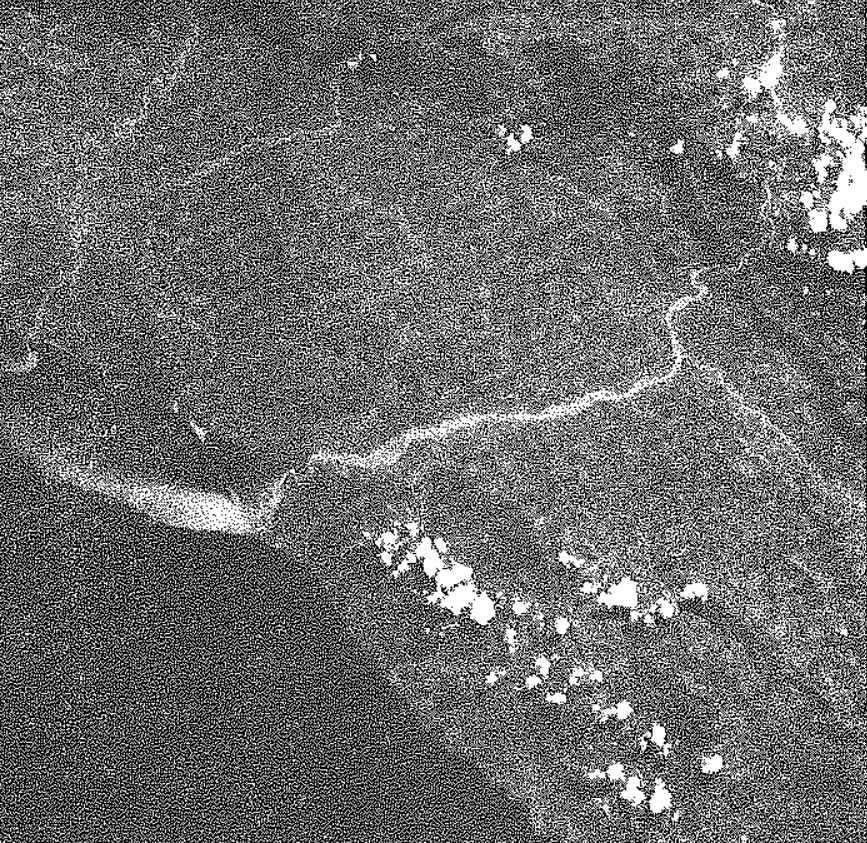


Figure 8: Wind stress (3-day average) calculated from wind speed and wind direction at the weather station Amasra, Turkey, at $10 \mathrm{~m}$ above sea level. Results are based on three measurements per day (Hydrographic Institute of Turkey, Ankara, unpub1. data). 


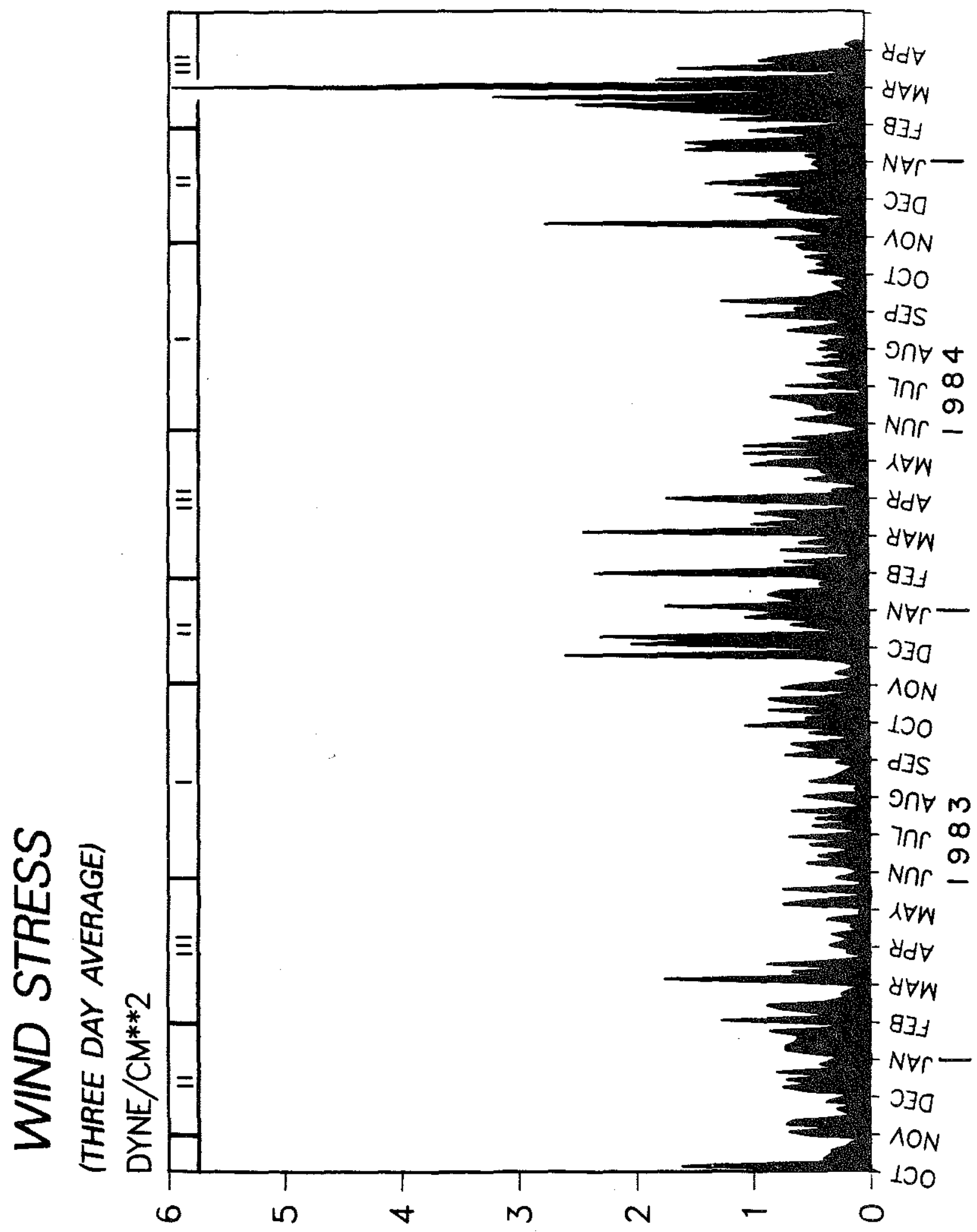




\subsubsection{Wind Stress}

The wind speed in Amasra varies seasonally and annually (Fig. 8). Wind speeds were consistently highest from November to April within the three year data record. Mean daily wind stress calculated from the wind speed for Phase I was 0.58 , for Phase II 0.97 , and for Phase III 0.85 dyne $\mathrm{cm}^{-2}$. The annual daily average based on a three year record was 0.77 dyne $\mathrm{cm}^{-2}$. The wind stress varied between the individual phases for the different years 1982 to 1985 by $\pm 7 \%$ for Phase I, $\pm 38 \%$ for Phase II, and $\pm 88 \%$ for Phase III, indicating that Phase $I$ is a relatively quiet season with weak winds, Phase II a season with strong winds, and Phase III a season with also rather strong winds but more short-1ived. Throughout the year, winds are predominantly easterly and southerly.

\subsection{INTERACTION BETWEEN LITHOGENIC AND BIOGENIC PARTICLES}

\subsubsection{Sinking speed of particles}

The sinking speed of the particles in the water column between the $250 \mathrm{~m}$ and the 1,200 m trap varies with season. Sinking speed can be estimated from the offset in the $\mathrm{Corg} /\left(\mathrm{CaCO}_{3}+\mathrm{Si}_{\mathrm{b} 1 \circ \mathrm{g}}\right)$ ratio for the two traps for the year of coordinated sample collection in the time period between 1983 and 1984 (see section 1.4.2. for an explanation of 
this ratio.) An offset can also be seen in the organic carbon flux during this time period; however, the ratio is preferable since it eliminates the effect of patchiness. Cross-correlation of the $\mathrm{Corg} /\left(\mathrm{CaCO}_{3}+\mathrm{Si}_{\mathrm{blog}}\right)$ ratios of the 250 and $1,200 \mathrm{~m}$ traps showed that the offset in Phase I in 1983 of one to two sampling intervals (i.e. 11.3 - 22.7 days), indicated a speed of around $65 \pm 22 \mathrm{~m} /$ day during the summer and the months of September and October (Figs. 9a \& 10), the time period of high biological production and quiet seas. The offset in winter and spring (Phases II and III) between 1983 and 1984, in the 1ithogenic/non-1ithogenic distribution of zero to one sampling interval (i.e. 0 - 15.3 days), indicated a settling speed of around 125 $\pm 60 \mathrm{~m} /$ day (Fig. 9c). The higher sinking speed in the winter and spring may be related to the lower organic carbon content in the particle flux during these seasons which could reduce settling due to its lower specific gravity. Organic carbon $f l u x$ represents on average about $20 \%$ of the total flux in Phase I and about $6 \%$ in Phases II \& III.

\subsubsection{Direct settling versus resuspension of particles}

A considerable amount of material that reaches the basin floor is initially produced over shelves and later resuspended by storms and transported offshelf. Rodolfo et al. (1971) showed that the concentration of suspended particles on the Atlantic shelf near North 
Figure 9: Ratios and percent distributions of major components of the particle flux.

(a) Organic carbon/carbonate plus biogenic silicate ratio of particulate flux at $250 \mathrm{~m}$ and $1,200 \mathrm{~m}$. The numerator reflects the organic carbon derived from primary production. The denominator reflects predominantly the mineralized skeletal components of biogenic particles derived from coccolithophorids, diatoms, and silicoflagellates.

(b) Percent distribution of the carbonate and biogenic silica fluxes within the total particle flux at $250 \mathrm{~m}$ and $1,200 \mathrm{~m}$.

(c) Percent distribution of 1ithogenic and non-lithogenic flux of the total particle flux at $250 \mathrm{~m}$ and $1,200 \mathrm{~m}$. 


Figure 10: Cross-correlation between the organic carbon/carbonate plus biogenic silicate ratio of the $250 \mathrm{~m}$ and $1,200 \mathrm{~m}$ trap for Phase I in 1983. One lag offset corresponds to one samp1ing interval, which is 11.3 days. The cross-correlation coefficient was highest at 1 ag 1 (i.e. 11.3 days): 0.68 . 


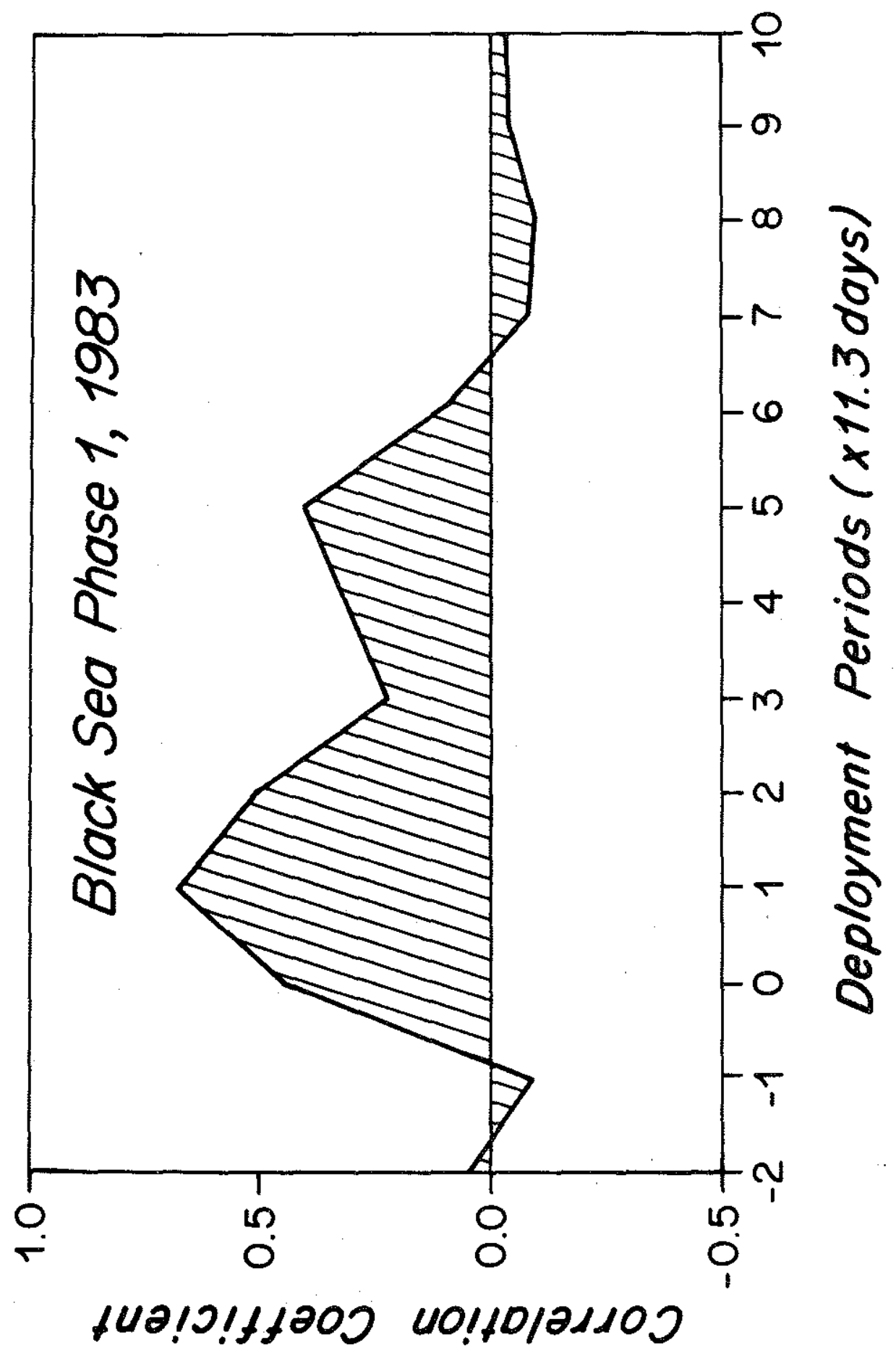


Carolina increased by more than a factor of two over pre-storm values by the passage of a hurricane. Concentrations returned to pre-storm value within a week. In a detailed study of the Yellow Sea between China and Korea, Wells et a1. (1983) documented that monsoon winds in winter are the primary driving mechanism for sediment accumulation and regional sediment dispersal.

In the Black Sea, biogenic particles produced over the aerobic shelf are degraded more than biogenic particles that settle immediately into the anoxic surface water. This characteristic can be utilized to separate the time period of the actual summer bloom in the surface water from the time period of resuspension of photosynthetically produced, mineralized tissue material by calculating the ratio between the organic portion of the primary produced particles and the skeletal portion of these particles ( $\mathrm{Corg}_{0} /\left(\mathrm{CaCO}_{3}+\mathrm{Si}_{\mathrm{bi}}\right.$ og. ratio) (Fig. 9a).

While the organic fraction of the primary produced particles is best represented by the organic carbon flux, the skeletal portion of these particles is best represented by adding the biogenic silica and the carbonate flux. SEM analysis of the sediment trap samples showed that the dominant marine organisms that contribute to the particle flux are diatoms, silicoflagellates, and coccolithophorids. The contribution of carbon from bacteria and dinoflagellates is considered insignificant. Selected bacteria counts in the sediment trap material of the $250 \mathrm{~m}$ trap revealed that the estimated contribution of bacterial 
biomass to the particulate organic carbon content contributes less than $4 \%$ (Nicholson, 1986, pers. comm.). The qualitative study of dinoflagellates indicated a contribution to the biomass of less than $3 \%$ (Jacobsen, 1986, pers. comm.).

In the numerator, the value for the organic carbon flux represents carbon derived mostly from originally primary-produced material. Shimkus and Trimonis (1974) calculated that less than one tenth of the total particulate organic matter is brought in by rivers. Based on the analysis of one sample of suspended sediment from the mouth of the Kocacay, the contribution of terrestrial organic carbon to the total annual organic carbon $f l u x$ measured in the traps represented about $4 \%$, assuming that the ratio of lithogenics to terrestrial organic carbon in the river sample remained the same during the transport to the basin floor of the Black Sea.

In the denominator, the value for the biogenic silica flux represents essentially diatom frustules and silicoflagellate skeletons. The majority of the carbonate flux was contributed by Emiliania huxleyi. The estimated contribution of terrigenous carbonate to the trap site area was $6.5 \%$ of the total carbonate flux.

Thus the $\mathrm{Corg}_{0} /\left(\mathrm{CaCO}_{3}+\mathrm{Si}_{b_{1}} \circ \mathrm{g}.\right)$ ratio is essentially a ratio between the remaining organic fraction of the primary-produced material (numerator) and the corresponding skeletal fraction (denominator). In 
Phase I, the ratio showed a distinct peak in 1983 and 1984 (Fig. 9a). In Phase II and III the ratio was considerably lower in a11 years, with the exception of Phase III in 1983. However, at the same time the wind stress during this phase in 1983 was relatively low (Fig. 8), the lithogenic and carbonate content was relatively small, and the biogenic silica content was relatively high. These data suggests that the relatively higher $\mathrm{Corg}_{0} /\left(\mathrm{CaCO}_{3}+\mathrm{Si}_{\mathrm{b} l o g}\right)$ ratio in Phase III in 1983 was caused by a smaller input of calcareous particles from the river and the aerobic shelf due to lower wind stress; during the period after the spring bloom of siliceous phytoplankton the flux of biogenic particles that settled directly into the deeper water was higher than in other periods.

A large difference in the $\mathrm{C}_{0 r g} /\left(\mathrm{CaCO}_{3}+\mathrm{Si}_{\mathrm{b}}\right.$ og. $)$ ratio could have resulted from different particles produced by different phytoplankton groups. However, as shown by the distribution between carbonate and biogenic silica (Fig. 9b), the carbonate contribution was large both in Phases I and II in both traps (Table 2). High carbonate content indicated that at least for Phases I and II there were no distinct differences in phytoplankton assemblage with potentially different organic tissue/shell ratios.

These results suggest that in the Black Sea the $\mathrm{C}_{\circ \mathrm{rg}} /\left(\mathrm{CaCO}_{3}+\mathrm{Si}_{\mathrm{b} \perp \circ g}\right)$ ratio can be used to distinguish between the biogenic matter that directly settles into the anoxic deeper water and 
material that first settled onto the shelf and is resuspended and transported offshelf at a later time. The particle composition during Phase $I$ is made up of a considerably higher proportion of the biogenic matter that settled directly into the anoxic deeper water after the coccolithophorid bloom in the summer. With the onset of the winter storms in Phase II, a large amount of biogenic particles, mostly Emiliania huxleyi, is resuspended from the shelf. In Phase III, the biogenic particles were still derived from resuspension as indicated by the low Corg $/\left(\mathrm{CaCO}_{3}+\mathrm{Si}_{\mathrm{b}}\right.$ og $)$ ratio.

\subsubsection{Lithogenic particle supply}

The significance of input of terrestrial detritus in relation to biogenic particulate material can be assessed by calculating the percent distribution of the lithogenic flux with the non-1ithogenic flux. In this study the non-lithogenic flux is defined as the difference between the total flux and the lithogenic flux (Fig. 9c). The non-lithogenic flux represented predominantly materials from primary production in the surface water.

Terrestrial detritus also includes some river-transported organic detritus and terrigenous carbonates, which reduce the division of this ratio between biogenic matter and river-transported material somewhat, though not significantly. The concentration of organic matter in the 
Kocacay in October 1984 was $1.1 \%$. The carbonate content of the detritus in the Sakarya Nehri was measured as $15 \%$ (Mü1ler and Stoffers, 1974), and in the Kocacay as $14.7 \%$ (October 1984). Trimonis (1974) estimated the carbonate contribution from river input in the Black Sea sediments as $5 \%$. The contribution of detrital carbonate in the total carbonate flux can be estimated by using a terrigenous carbonate concentration of $15 \%$, which translates into a ratio between detrital carbonate and 1ithogenic non-carbonate particles of 1:5.67. By applying this ratio to the average annual lithogenic component in the flux of the two traps ( $37 \%$ ), under the assumption that the ratio remained the same, the detrital carbonate concentration was estimated to be $7 \%$ of the total flux.

The distribution of the lithogenic versus non-lithogenic flux in the sediment traps therefore approximates the distribution of the terrigenous particle $\mathrm{flux}$ in comparison to the biogenic flux in the Black Sea. The distribution of the 1ithogenic flux with the non-lithogenic flux showed the following trend (Fig. 9c; Table 2): The largest contribution of lithogenic particles to the total flux was found in Phase III. Mean values of the lithogenic flux were lower for Phase II and, especially, for Phase I. The single highest value was in the $250 \mathrm{~m}$ trap during Phase II (Nov. 14-30, 1983) which contained $71 \%$ lithogenic particles. The distribution for the $250 \mathrm{~m}$ and $1,200 \mathrm{~m}$ traps corresponded comparatively well in total concentrations (specifically during Phase III in 1984), with second order peaks offset either not at 
all or by one sampling interval. A prominent peak in Phase $I$ in August 1983 is related to the intense rainfall in Amasra during the previous sampling period. The means of the lithogenic flux for the $250 \mathrm{~m}$ and $1,200 \mathrm{~m}$ traps during deployments BS2 and BS3 (Table 1) were $36 \%$ and 40 $\%$ of the total flux. These data suggest common sources of particles for both traps during those phases, despite considerable variability in the total flux between the $250 \mathrm{~m}$ and $1,200 \mathrm{~m}$ trap in individual sampling interva1s.

\subsection{OFFSHORE PARTICLE TRANSPORT FROM LAND - DISCUSSION}

The high wind stress during Phases II and III corresponded with the low $\mathrm{C}_{\text {org }} /\left(\mathrm{CaCO}_{3}+\mathrm{Si}_{\text {biog }}\right)$ ratio in both the $250 \mathrm{~m}$ and $1,200 \mathrm{~m}$ traps. In contrast to the high ratio during the summer/fall coccolithophorid bloom, the low ratio in winter/spring indicated that these coccoliths were exposed to aerobic degradation of organic carbon, and thus appear that they were supplied from the shelf.

Storm-resuspended and river-introduced sediment is possibly dispersed offshelf as a turbid layer by advection and diffusion along the pronounced pycnocline at $175 \pm 50 \mathrm{~m}$ caused by the significant salinity contrast between the surface and the deep waters. Evidence for a turbid layer of suspended particles in most parts of the Black sea at around $150 \mathrm{~m}$ was given by Neuymin (1973). Neuymin (1973) reported that 
Figure 11: Conceptual diagram of sediment sources and dispersal mechanisms along the southern Black Sea margin, near trap station BS. The vertical exageration factor is 11 above and 5.5 below the suspended sediment layer (SSL). (Notice the change in vertical scale at $200 \mathrm{~m}$.$) Horizontally, shelf and$ slope widths and location of the sediment trap mooring are to scale. The slope gradient represents the average gradient; not included on the slope are the tectonically induced "pu11-apart" basins. The direction of the coast-paralle1 surface current (1) is ENE. The dominant dispersal mechanisms are gravity transport processes, in the form of turbidites (2) and slumps (3), and transport of suspended sediment along density gradients (SSL). Three major processes control the variability of the hemipelagic sedimentation on an annual basis: (i) primary production, (ii) river input of particulate matter (4), and (iii) storm-induced resuspension of settled lithogenic and photosynthetically produced material from the shelf (5). The hemipelagic sediment is transported of $f$ shelf by advection and diffusion and settles out in decreasing concentrations with distance from shore $(6 a, 6 b)$. 


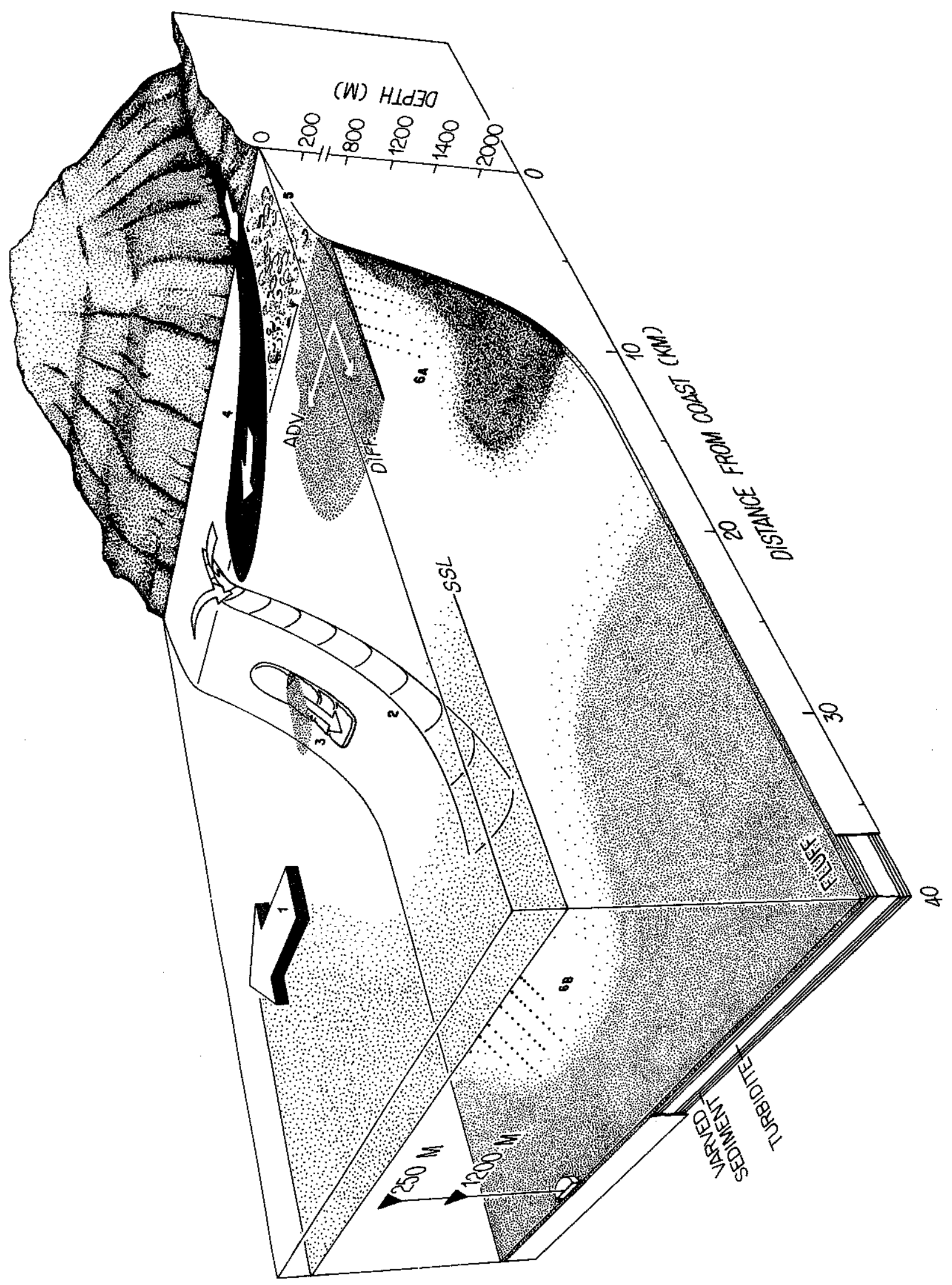


the suspended material was composed primarily of fecal pellets and decaying phytoplankton.

The particle flux in offshore areas was closely related to storms which vigorously mix the surface water and thereby disturb the turbid layer at the pycnocline or any other minor density surface like the thermocline (Neuymin, 1973). Lack of storm activity in summer and early fall (Phase I) leads to a well-stratified water column with a well-defined thermocline (Degens et a1., 1984). Surface water is destratified during the intense winter and spring storms (Phases II and III). Increased turbulence may lead to enhanced coagulation between suspended particles at the beginning of the storm season. This mechanism could contribute to the unusually large total flux in December observed each year, especially in 1983, where it coincided with the first intense storm during that winter. Resuspension of shelf sediments by winter storms was also recognized as a major contributor in of $f$ shore sedimentation in the East China Sea (Milliman et a1., 1985a).

The array of 1ithogenic sources of sediment supply and dispersal mechanisms of sediment to the Black Sea basin floor at a near-shore, deep station are summarized in Figure 11. These sources and mechanisms possibly were responsible for generating the sedimentary record on the Black Sea basin floor for at least the last 5,000 years, during which the anoxic bottom water condition preserved a continuous laminated sedimentary sequence (Ross and Degens, 1974; Degens et a1., 1980). The 
dispersal mechanisms can be divided into gravity-driven flows which resulted in the turbidite beds within the bottom sediments, and of $f$ shelf transport of suspended particles by an intricate interaction of physical (storm and current) and chemical (strong pycnocline) factors, in combination with biological and physical particle settling mechanisms (Fig. 11). However, the strong influence of shallow coastal detritus specific to the southern Black Sea mooring site is not duplicated in central abyssal plain stations.

\subsection{CONCLUSIONS}

The annual cycle of the particle flux at a trap mooring site near Amasra, southern Black Sea, can be grouped into three distinct phases (Fig. 12). On a relative scale, Phase I (June - October) was characterized by a coccolithophorid bloom, large organic carbon and nitrogen fluxes, small lithogenic flux, small biogenic silica flux, low wind stress, and low river discharge. Phase II (November - January) was characterized by large lithogenic flux, high river discharge, large input of resuspended coccoliths, high wind stress, small organic carbon flux, and small biogenic silica flux. Phase III (February - May) was characterized by a period of high river discharge, high wind stress, large lithogenic flux, relatively small organic carbon $f l u x$, and an associated bloom of siliceous organisms (diatoms and silicoflagellates) which explained the large opal flux. The black laminae in the pelagic 
Figure 12: Dominant characteristics of the individual phases of the annual particle flux in the Black Sea. The size of the black circles depict the relative importance of individual factors for different phases in contributing particle fluxes. 


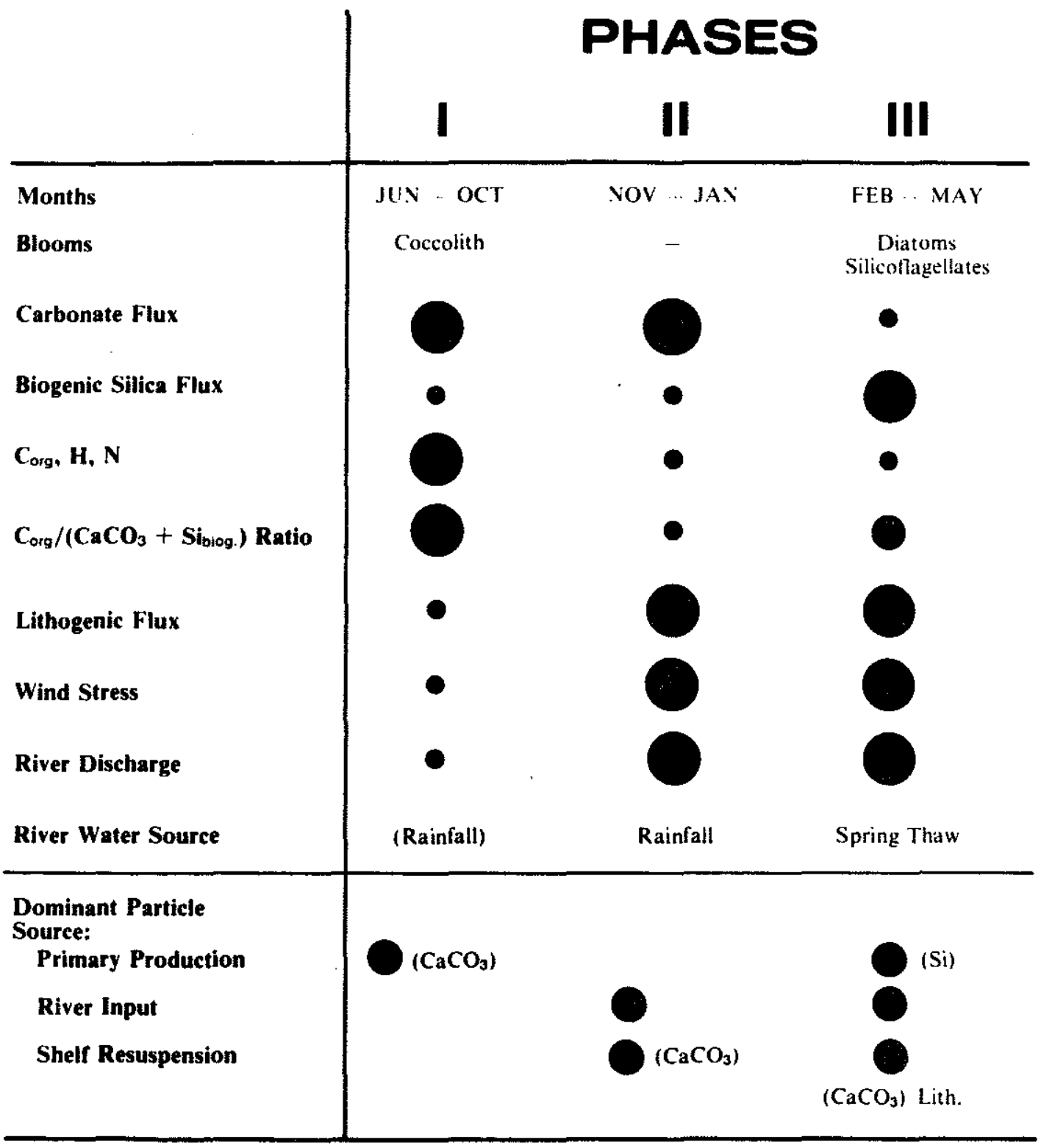


sediments appear to be deposited during Phase III, whereas the coccolith-rich white laminae are formed during Phases I and II.

Dominant sources of lithogenic flux to this site were the Filyos and Kocacay. High river input and increased lithogenic flux are we11 correlated in August (irregularly) and in November and December due to high rainfalls, and in March and April because of the spring thaw. Lithogenic and biogenic particles that settled on the shelf were resuspended by high orbital speeds on the shelf floor during the period of frequent storm activity, particularly between November and April. The resuspended particles consisted predominantly of lithogenic particles and coccoliths (especially between November and February). Estimated particle sinking speeds varied between $65 \mathrm{~m} /$ day in summer and fall and $125 \mathrm{~m} /$ day in winter and spring at this station. 
Chapter 2

PARTICLE FLUX IN THE WESTERN BLACK SEA

THROUGHOUT THE PAST 5,000 YEARS

WITH COMPARISON OF THE PRESENT FLUX 
Compared to the present-day particle flux in the southwestern Black Sea (2 1/2 year record), the particle flux over the last 1,000 years (paleoflux) in the western Black Sea is higher by a factor of 5.5 , most1y because of an 11 times higher carbonate paleoflux; the paleoflux of lithogenic particles is higher only by a factor of 3 . Most of the variability in the paleoflux is a function of the variability in the supply of coccoliths from Emiliania huxleyi. The contrast between paleoflux and present-day particle flux in the southwestern Black sea is a function of different parameters in the particle supply. Particles in the central part of the western Black Sea are supplied predominantly from the northwestern shelf while particles in the southwestern Black Sea are supplied from the Anatolian mountains. The paleoflux between 1,000 and 5,000 years B.P. (unit II) is lower by a factor of 3 compared to the last 1,000 years (unit I). Most of the variability in the paleoflux in unit II is a result of the variability in the supply of terrigenous matter.

Comparison of the laminated core sediments with seasonal dynamics in particle supply in the southwestern Black Sea suggests that white laminae (over $90 \%$ carbonate) formed during summer and fall, whereas black laminae (most1y clay minerals) formed during winter and spring. 


\subsection{INTRODUCTION}

The Black Sea represents a useful environment for the study of annual particle flux of the past (paleoflux). Because anoxic conditions prevail below about $175 \mathrm{~m}$, particles that settle into the deep water experience comparatively little alteration in the water column and on the basin floor. Lack of oxygen in the deep water prohibits bioturbation in the sediment and thus permits preservation of the seasonal signature of particle flux in the sediment record as laminated sediment. Assuming that the laminae in the Black Sea are the result of seasonal variability in the particle flux (see section 2.3.3.), then by knowing the parameters that influence seasonality of the present-day particle flux, the history of change in these parameters can be reconstructed in the laminated core sediment. Linking the detailed knowledge of the seasonal variability in the particle flux in the present with the 5,000 year long time-series of the laminated sediment record offers the possibility of a detailed understanding of the seasonal and long-term changes in the particle sources and regional transport processes of this basin.

Laminated sediments have been known from the abyssal plain of the Black Sea for nearly a century. Pelagic sediments were studied for the first time through coring by Andrusov in 1890. More extensive work was carried out by Arkhangel'skii and Strakhov in 1927, who observed the 
high organic carbon enrichment as well as the laminated nature of the sediments. More recent extensive studies include the $R / V$ ATLANTIS II cruise 4 \# in 1969 (Degens and Ross, 1974) and the Deep Sea Drilling Program, Leg 42B (Ross and Neprochnov, et a1., 1978).

Laminae of different colors were observed in all of the upper meters of the sediment column (e.g. Ross and Degens, 1974). Murray (1900) first ascribed the white "amorphous" carbonate phases to inorganic precipitation. This conclusion was consistent with the observation by Androsov (1890) who found only very few organisms in the fine carbonate muds. The low MgO concentration ( $<1 \%)$ in the calcite led Arkhangel'skii and Strakov (1927, 1932, 1938) to postulate that the micro-lamination of the fine calcite was "drewite" formed as a product of metabolic processes of bacteria. Later, Strakhov (1947) agreed with Murray (1900) when he estimated that the entire carbonate sedimentary budget of the Black Sea consisted of about $50 \%$ inorganic precipitates, 15-20\% detrital products, $17 \%$ biogenic matter and less than $13 \%$ bacteriological products. Zenkovitch (1966) ascribed the lamination to seasonal events observed in the surface waters:

"A varve-1ike parting of organic matter reflects the dying off of plankton in summer and autumn. A fine-grained layer of calcite is deposited in winter, and a thin layer of clay in spring."

Even though species of coccolithophoroids were first recorded to be present in surface waters by Usatchev (1947), it was not until the $R / V$ ATLANTIS cruise in 1969 that the white bands were recognized as almost 
exclusively cocolith deposits (Bukry et a1, 1970). The black laminae were described as mostly terrigenous deposits (e.g. Muiller and Stoffers, 1974). Assuning annual deposition of one black and white varve couplet, the laminated sediments were used in this study to determine seasonaj. and annual variability in the paleoflux over the last 5,000 years in the western Black Sea.

Results from the study of present seascnal biogeochemical processes in the Black Sea (chapter 1) were incorporated in reconstructing the seasonal variability in the paleoflux of the past in the Black Sea which resulted in the laminated sediments. The focus of this chapter was (i) to investigate the changes in paleoflux throughout the anoxic past of the Black Sea, and (ii) to compare the annual paleoflux over the anoxic history with the present-day particle flux in order to better understand the spatial and temporal variability in the annual hemipelagic deposition in the Black Sea.

\subsection{LITHOLOGY OF THE LAMINATED SEDIMENTS - BACKGROUND}

The hemipelagic sediments that were deposited in the central Black Sea throughout its anoxic past are separated into two basic units that are traceable over the entire basin (Degens and Ross, 1974):

1) Unit I, or coccolith ooze (Fig. 13a), is generally about $30 \mathrm{~cm}$ thick 
Figure 13: (a) Photomicrograph of unit I from core 18. The approximate age of the sediment is 600 years B.P. The white bands are composed of over $90 \%$ carbonate whereas the black bands are composed of terrigenous particles. (Scale: vertical length: $1 \mathrm{~mm})$

(b) Photomicrograph of unit II from core 18. The approximate age of the sediment is 2,000 years B.P. Both bands are composed of mostly terrigenous material. The carbonate content in both bands is less than $20 \%$ (Scale: vertical length: $1 \mathrm{~mm}$ ) 

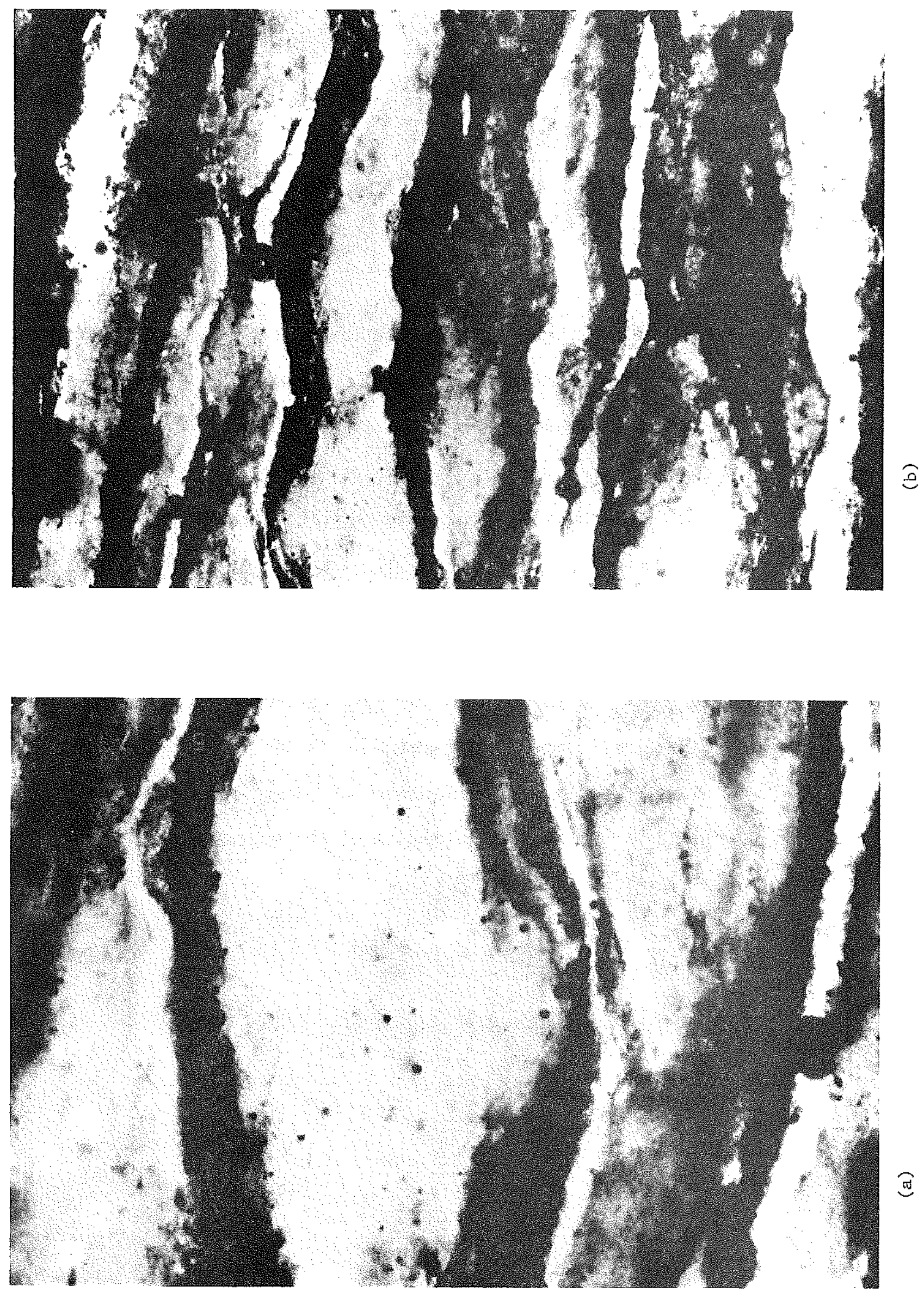
Figure 14: (a) SEM photograph of a black lamina from sediment unit I in core 18 (horizontal natural cleavage by drying). The approximate age of the sediment is 600 years B.P. Note high concentration of clay particles and the occurrence of the coccolithophorid Emiliania huxleyi. (Scale on the bottom of the micrograph.)

(b) SEM photograph of a white laminae from sediment unit I in core 18 (horizontal natural cleavage by drying). The approximate age of the sediment is 600 years B.P. Note the almost exclusive occurrence of the coccolith Emiliania huxleyi. (Scale on the bottom of the micrograph.) 

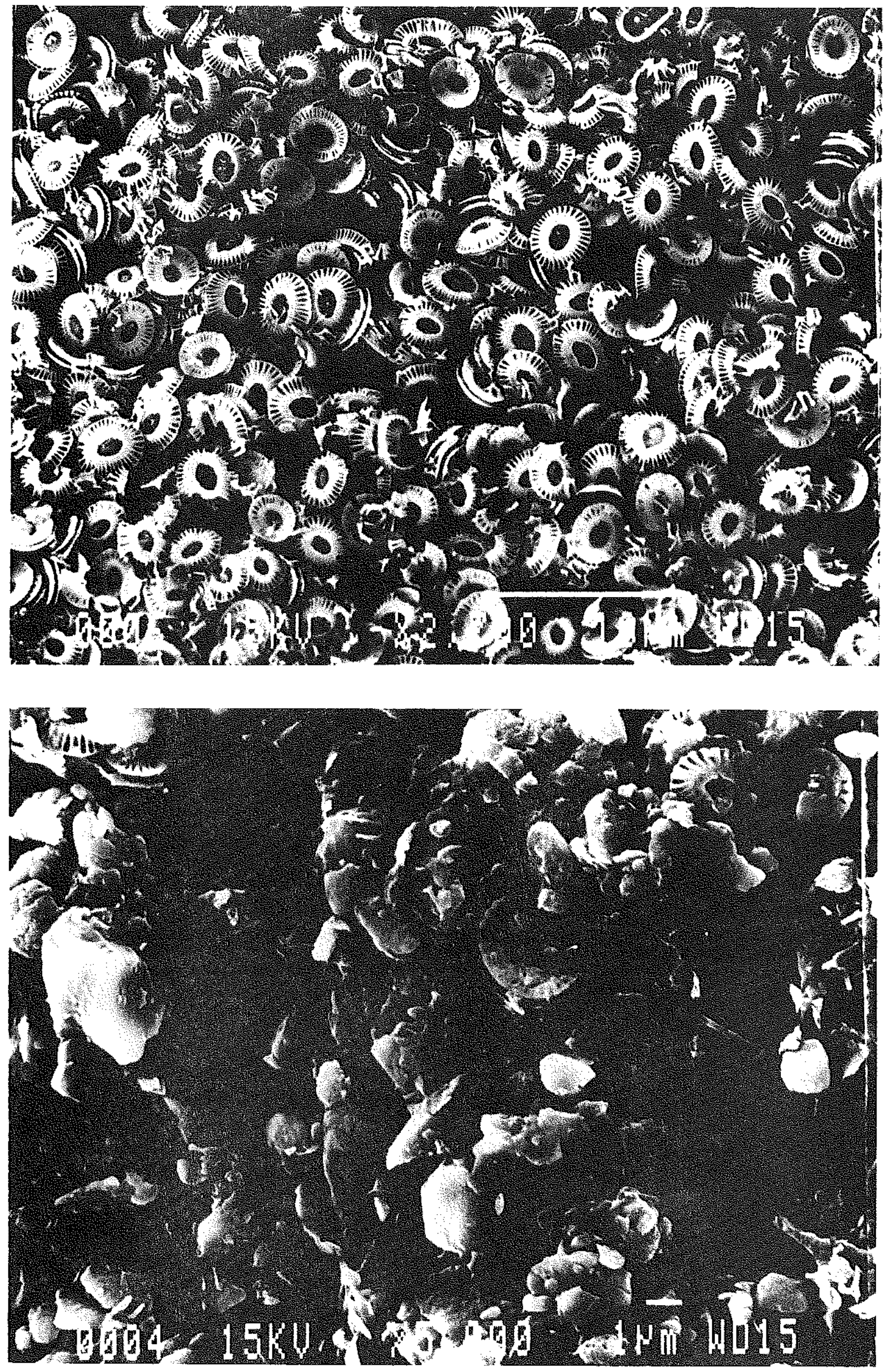
in the central Black Sea (Ross and Degens, 1974), but is thicker in areas with high terrigenous sediment contribution. This sediment unit consists of finely laminated layers with an average thickness of $0.1-0.4$ $\mathrm{mm}$ in the central Black Sea. However, laminae are not recognizable in the upper slopes of the Danube fan and in nearshore regions. The dominant species is Emiliania huxleyi (Fig. 14a). Black bands are composed mostly of clays with a minor contribution of coccolith carbonate. The organic carbon content is about $4 \%$ (Degens, 1974). The microfaunal assemblage in the black bands consist of in-situ coccoliths and Cretacecous and Eocene erratal coccoliths, transported into the basin by rivers from the Anatolian Massif (Bukry, 1974).

2) Unit II, is a saprope1 (Fig. 13b), averaging about in $40 \mathrm{~cm}$ thickness (Ross and Degens, 1974). It is thickened and obscured in areas of high deposition rate. This unit is also laminated, exhibiting up to 100 varve couplets per centimeter (Fig. 14b). The sediment is dark brown in color and high in organic carbon content (10-20\%, Degens, 1974).

\subsection{METHODS}

\subsubsection{Sample analysis}

For the study of the paleoflux three laminated cores were chosen from the R/V CHAIN cruise in 1975 (Fig. 15). Samples were collected 
with a gravity corer with a specially developed method that preserved the sediment surface and laminae (Degens et al., 1980). Core sites were located in the deep western part of the Black Sea ( $5 \& 18)$, about 100-150 km northeast of the trap site in the deep part of the basin (Fig. 1). Cores had been refrigerated at the University of Hamburg. A total of 56 samples were studied from cores 5 (18 samples), 18 (32 samples), and 35 ( 6 samples). The samples from unit II of core 35 were chosen from younger than 2,800 years B.P. (Fig. 15), which represents the approximate date when the $\mathrm{H}_{2} \mathrm{~S} / \mathrm{O}_{2}$ interface was shallow enough to cause anoxic deposition on the upper slope.

For the measurement of the paleoflux from the sediment cores a small rectangular block of sediment was cut parallel and vertical to the laminae. The average wet volume was about $254 \mathrm{~mm}^{3}$. Paleoflux, measured like the present-day particle flux in the units weight/area/time, was determined for each sample in three basic steps (Fig. 16):

1. Time: A $1 \mathrm{~mm}$ thick slice was cut from one of the sides of each small block perpendicular to the laminae with a single-edged blade and mounted for thin-sectioning. The number of years of deposition for each block was determined by varve counting. I assumed that one light and dark varve couplet represented one year (see next section for further discussion). On average, sediment blocks from unit I used or analysis had 28 varve couplets, blocks from unit II had 73 
Figure 15: Stratigraphic cross-section of the three cores used for the paleoflux study (after Degens et a1., 1980). The sediments consist of laminated hemipelagic deposits interbedded with turbidite oozes. The main sedimentary units were dated by varve-counting; the ages 487 and 624 years B.P. were derived from correlation with additional cores by Degens et a1. (1980). 


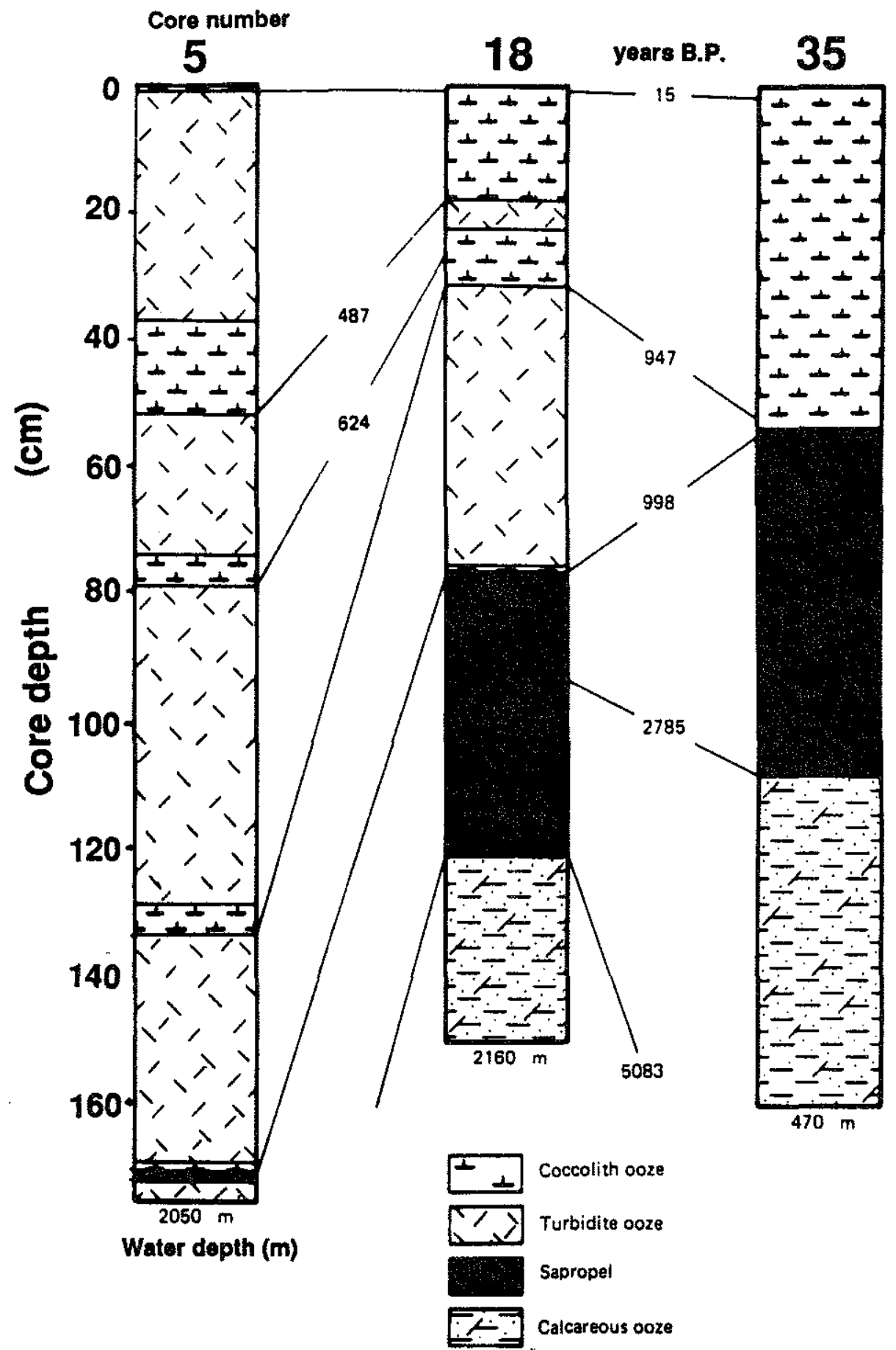


Figure 16: Schematic diagram of the method used in the determination of the postdepositional paleoflux (PPF) and the depositional paleoflux (dPF) for the laminated sediments of units I \& II. 


\section{PALEOFLUX DETERMINATION IN LAMINATED BLACK SEA SEDIMENTS}

1) FLUX (Weight /Area/Time)
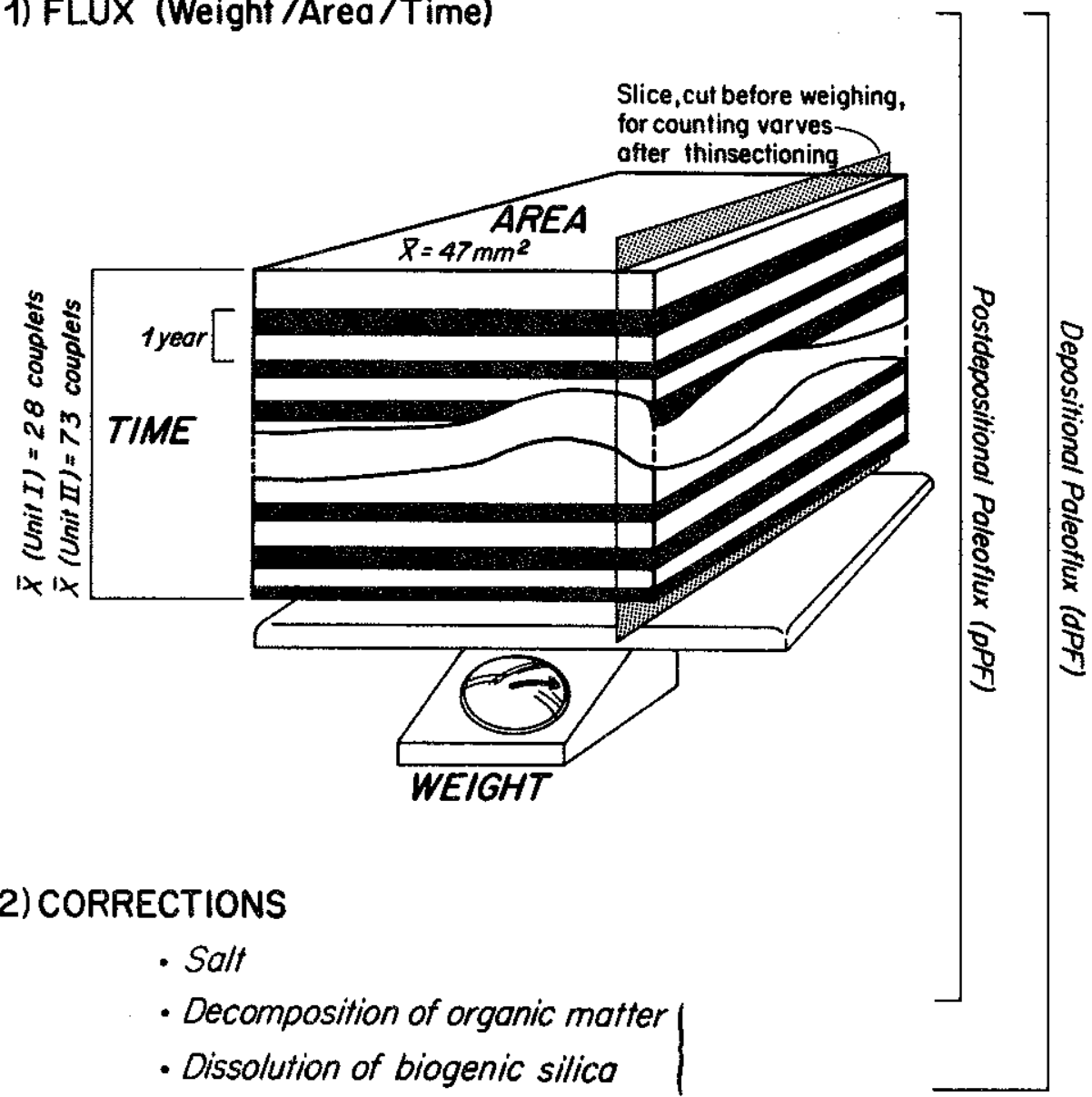

2) CORRECTIONS

- Salt

- Decomposition of organic matter

- Dissolution of biogenic silico 
couplets (Fig. 16). The average error in varve counting is estimated with $\pm 6 \%$ in unit $I$ and $\pm 8 \%$ in Phase II. The error resulted from the fact that some varves could not be identified unambiguously as separate varves. The higher error in unit II is a result of thinner laminae in that unit.

2. Area: The surface and bottom area of each block was carefully measured and averaged (Fig. 16).

3. Weight: Each block was then dried at $60{ }^{\circ} \mathrm{C}$ for 24 hours and weighed. Samples were corrected for salt (see Table 3 ).

The methods for the bulk chemical analysis of the core samples were the same as used for the analysis of the sediment trap samples (chapter 1). For the determination of carbonate the dried sample was immersed in $10 \%$ acetic acid and ultrasonically dispersed. After 24 hours the sample was filtered, rinsed with distilled water, dried, and reweighed. The carbonate flux was determined from the weight loss. The organic carbon flux was determined from decalcified samples with a Hewlett-Packard $(R)$ CHN Analyzer. The noncombustible flux was determined by combusting the decalcified sample at $500{ }^{\circ} \mathrm{C}$ for 3 hours. The noncombustible matter therefore consists of lithogenic material and biogenic silica. The lithogenic content was computed by subtracting the estimated biogenic silica content in the sediment $(1.2$ $\%$; see section 2.3.2.2.) from the noncombustible content.

For the quantitative elemental analysis of individual laminae a JEOL 
Table 3: Table of assumptions and important values used for the salt correction and the calculation of the depositional paleoflux (dPF) from the postdepositional paleoflux (PPF).

\begin{tabular}{|c|c|c|}
\hline Porosity (at $\left.22 \%_{0}\right)$ & $80 \%$ & (Manhein and Chan, 1974) \\
\hline $\begin{array}{l}\text { Conversion factor for } \\
\text { Organic carbon to organic matter }\end{array}$ & 1.5 & (Honjo, unpub1. data) \\
\hline $\begin{array}{l}\text { Specific density } \\
\text { organic matter } \\
\text { inorganic matter }\end{array}$ & $\begin{array}{l}0.92 \\
2.7\end{array}$ & \\
\hline
\end{tabular}

(b) Values used for correction for silica dissolution and decomposition of organic matter in unit I

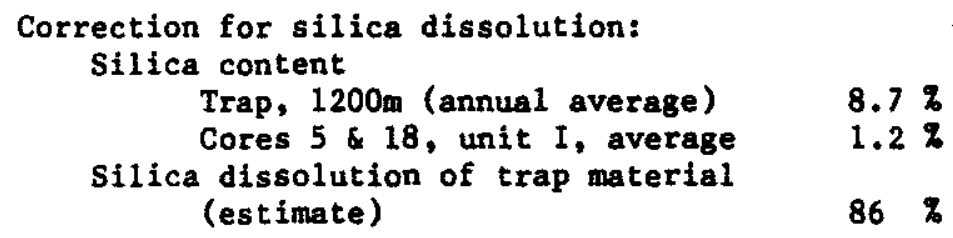

Correction for organic carbon decomposition: Organic carbon content Trap, 1200m (annual average) $\quad 14 \%$ Cores $5 \& 18$, unit $I$, average $4 \%$

Organic carbon decomposition of trap material (estimate) $70 \%$ 
JXA-733 SEM with a JSM-35CF/DDS electron microprobe was used. Sma11 core samples were dried at $60^{\circ} \mathrm{C}$ for $24 \mathrm{~h}$, embedded in EPOFIX epoxy, and kept under vacuum for another $24 \mathrm{~h}$ during hardening. The resulting stubs were then cut perpendicular to the laminae, and carefully polished. The microprobe was standardized before quantitative analysis of CaO using synthetic DJ35 glass. The error of this standard was less than $\pm 1 \%$.

\subsubsection{Data analysis}

\subsubsection{Sedimentation rate}

The sedimentation rates for units I \& II of the deep basin cores were computed as the average of the sedimentation rates of the blocks for each unit. The sedimentation rate for each block was calculated by dividing the thickness of the block by the number of counted varve couplets.

\subsubsection{Paleoflux}

For the quantitative discussion of the core data, the paleoflux (particle flux in the past) was further specified by the following two terms that are here defined: postdepositional paleoflux (pPF) and depositional paleoflux (dPF). The postdepositional paleoflux represents 
the paleoflux as calculated from the sample analysis steps (1) to (3) in section 2.3.1. The depositional paleoflux represents the paleoflux before postdepositional alterations such as decomposition and dissolution of matter has occurred in the sediment column (Fig. 16); it thereby represents the reconstructed paleoflux at the time of deposition to the ocean floor. The postdepositional paleoflux (pPF) is used in this study for the discussion of the changes throughout the anoxic past of the Black Sea (cores). The depositional paleoflux (dPF) is used for the comparison of the paleoflux of the recent past (unit I, cores) with the present-day flux (sediment traps). The term depositional paleoflux is equivalent with the term net accumulation rate also used in the literature (e.g. Curry and Lohmann, 1988, in prep.; Broecker and Peng, 1982).

For the Black Sea, the depositional paleoflux is computed by correcting for dissolution of biogenic silica and decomposition of organic matter (Fig. 17). Decalcification did not occur in Black Sea sediments (Fig. 14a; Bukry, 1974; Ross and Degens, 1974) and formation of authigenic minerals like pyrite is considered insignificant in terms of mass contribution to the sediment. Given the range of complexities involved in the degradation process of the biogenic matter and given the considerable regional variability, the correction values can only be estimates.

Correction for decomposition of organic matter: Deuser (1971) 
Figure 17: Schematic diagram of the computational step involved for the correction of the postdepositional paleoflux (pPF) for degradation of biogenic matter in order to obtain the depositional paleoflux (dPF). 
CORRECTION FOR DEGRADATION OF BIOGENIC MATTER IN UNIT I

1) Determination of correctlon factor

(Assumption: Constant decay in sediment after burial throughout unit 1

Oraanic matter

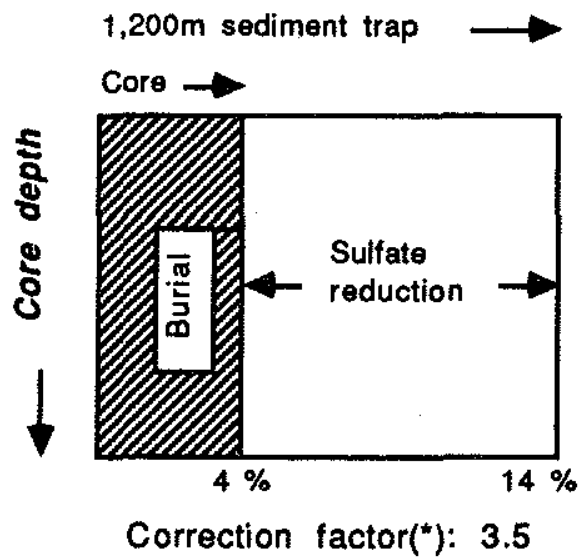

Blogenic sllica

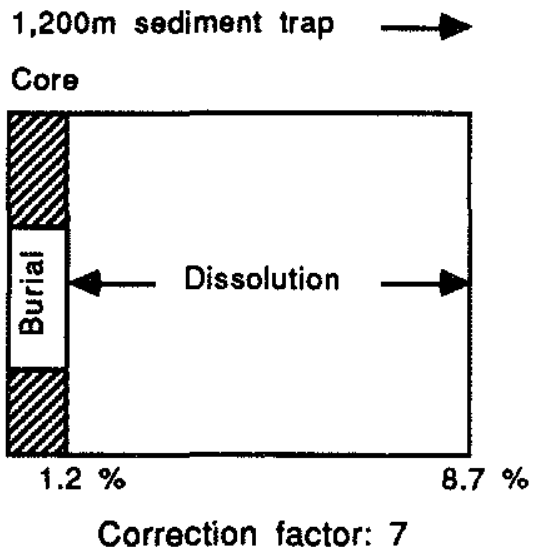

2) Calculation of Increase of postdepositional paleoflux

[i.e. Addition of the decomposed organic matter and dissolved biogenic silica to the total postdepositional paleoflux (PPF) to obtain the depositional paleoflux(dPF), i.e. the paleoflux before degradation had taken place]

\section{Oraanle matter}

Average increase: $61 \mathrm{mg} / \mathrm{m} 2 /$ day ("*) $=14 \%$ of $\mathrm{DPE}$

Range:
$39-83 \mathrm{mg} / \mathrm{m} 2 / \mathrm{day}$

$=9-19 \%$ of $\mathrm{pPF}$

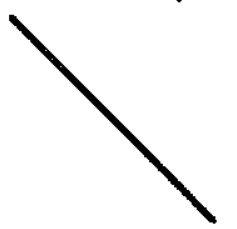

\section{Blogenle slllag}

Average increase: $31 \mathrm{mg} / \mathrm{m} 2 /$ day

$$
=7 \% \text { of } \mathrm{pPE}
$$

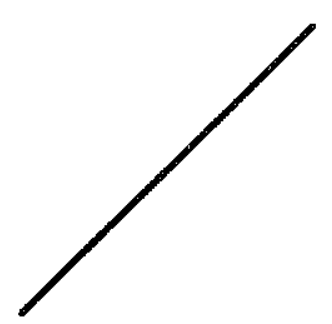

Total increase of paleoflux (pPF): $92 \mathrm{mg} / \mathrm{m} 2 /$ day (average)

$$
=21 \% \text { of pPF }
$$

(*) Organic matter values are based on organic carbon values.

(**) The values for the organic matter increase are based on organic carbon, multiplied by a factor of 1.5 (Honjo, unpublished data). 
Figure 18: Schema of the organic carbon budget for sediment unit I (taken from Deuser, 1971). Number below the squares represent grams of carbon per square meter per year over the area of the Black Sea. Considering that the sum is about 100 grams per square meter per year, the numbers also represent rough percentages. 


\section{FATE \\ OF ORGANIC MATTER}

DEPTH

(m)

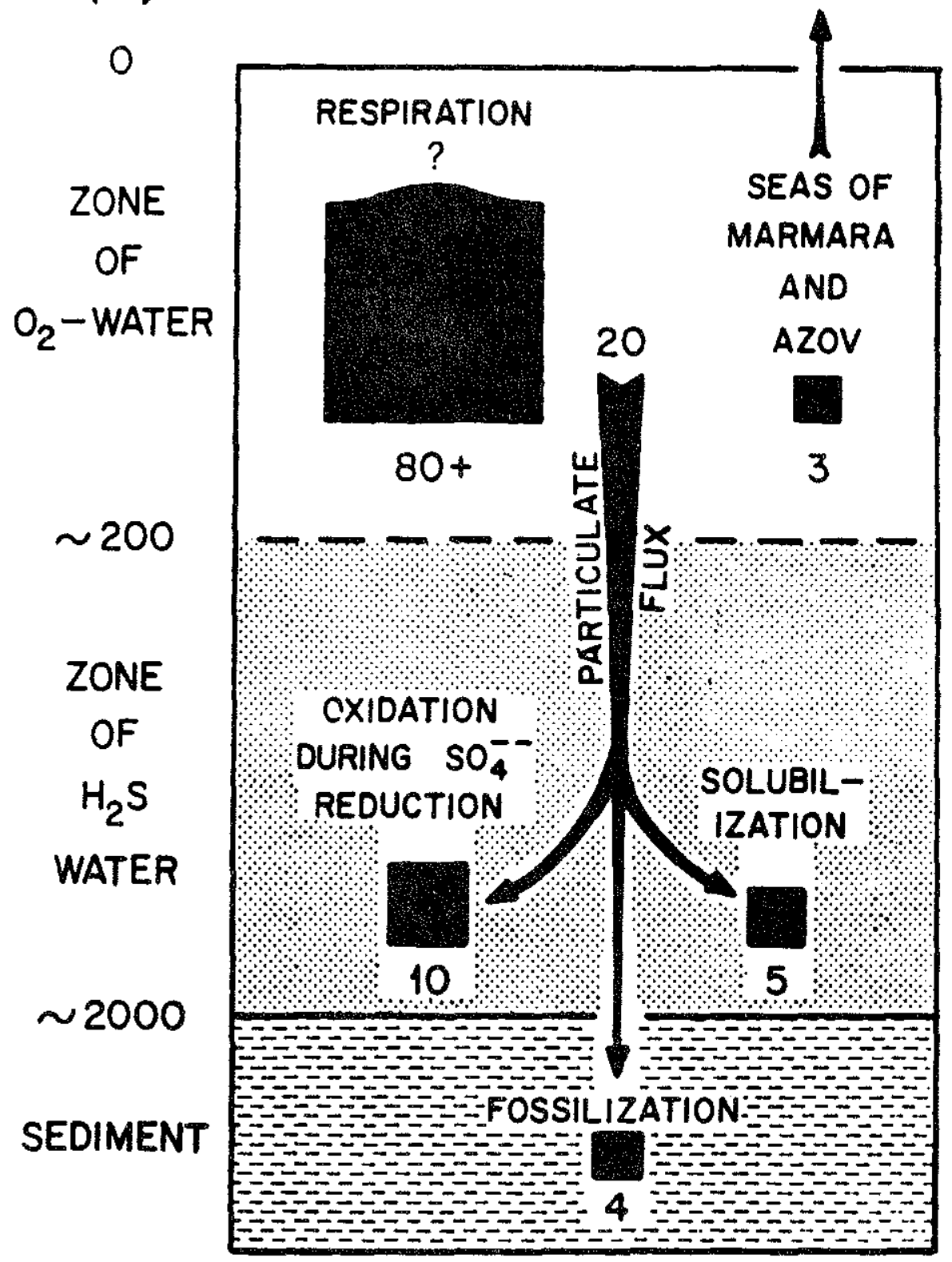


$-88-$

Figure 19: Organic carbon content (\%) in cores $5 \& 18$ for unit I \& II. The average organic carbon content in unit $I$ is $4.1 \%$, in unit II $10 \%$. 
Org. carbon, cores $5 \& 18$

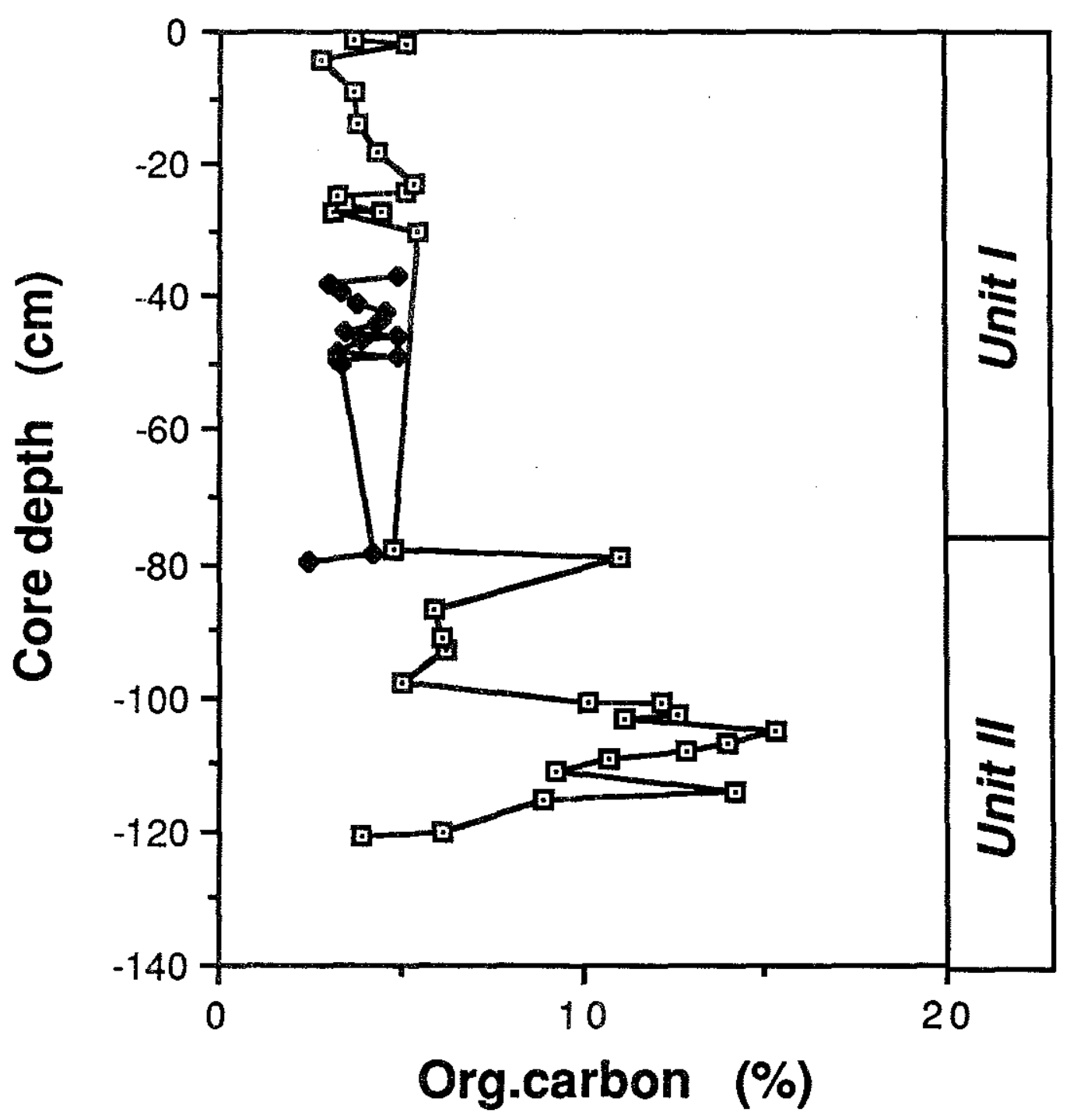


estimated that on1y $19 \%$ of the organic matter that enters the anoxic deep water would be buried in the sediment (Fig. 18). Of this $19 \%$, another $5 \%$ of the total organic matter dissolves in the water column and another $10 \%$ is oxidized by bacterial sulfate reduction at the sediment/water interface. The remaining $4 \%$ are finally buried in the sediment (Deuser, 1971). Further decay in the sediment column appears to be insignificant, since the relative concentration of organic carbon in cores $5 \& 18$ does not show any exponential decrease with depth over this short time span (Fig. 19). Also, in oxic sediment, the halflife of further decay of organic carbon has been estimated as long as about $1,000,000$ years in a core from West African shelf (Mï1ler et a1., 1983), and 114,000 years in a core from the Gulf of Mexico (Jasper, unpublished data). I therefore used a constant correction factor for each sample of unit I, independent of subbottom depth (Fig. 17). This factor was computed by comparing the organic carbon content of the sediment trap samples with the core samples. Considering that the average annual organic carbon flux represents $14 \%$ of the average total flux in the $1,200 \mathrm{~m}$ sediment trap, and that the average postdepositional paleoflux of organic carbon in cores $5 \& 18$ in unit I represents $4 \%$ of the total postdepositional paleoflux, decomposition of organic matter before final burial would be about $70 \%$, i.e. the original organic carbon flux in the deep water was higher by about a factor of 3.5 (Fig. 17). The postdepositional Corg paleoflux of each sample was then multiplied by this correction factor to obtain the depositional Corg paleoflux. Using an average conversion factor of 1.5 from organic carbon to organic 
matter and a density for organic matter of 0.92 , the total postdepositional paleoflux of each sample in unit I was then corrected for organic matter decomposition. On average, the total postdepositional paleoflux increased by about $14 \%$ with this correction (Fig. 17; Table 3).

Correction for dissolution of biogenic silica: Since the bottom waters in the Black Sea are undersaturated with respect to silica (Grasshoff, 1975), a large fraction of deposited biogenic silica will dissolve before final burial. The biogenic silica concentration of one core sample from the upper $20 \mathrm{~cm}$ from below the sediment trap site BS was $1.2 \%$ using the method by Eggimann et al. (1980). This value is similar to data from Shimkus et a1. (1973) who measured a biogenic silica content of $1.2 \%$ near core site 18 . Using the average annual biogenic silica flux of $8.7 \%$ of the total particle flux in the $1,200 \mathrm{~m}$ sediment trap and a residual biogenic silica content of $1.2 \%$ in the core sediments, the biogenic silica flux in the $1,200 \mathrm{~m}$ water depth dissolves by about $86 \%$ (Table 3), i.e. by a factor of 7.3 . With depth the biogenic silica content appears to be constant; Shimkus et al. (1973) measured the distribution of biogenic silica in three deep basin cores in the western Black Sea which showed a generally uniform distribution with depth for units I and II. When we then add the silica fraction that dissolved before burial, the total postdepositional paleoflux for each sample of unit I increases by about $7 \%$ This correction factor only represents a rough estimate, given the known difficulty in 
measuring the biogenic silica content in sediments (e.g. Eggiman et al., 1980).

\subsubsection{Postdepositional sediment accumulation}

An additional way to compare the present-day particle flux with the paleoflux of unit $I$ is to convert the present-day particle flux record of $21 / 2$ years from the trap site BS into a short hypothetical high-resolution core section, i.e. to calculate the postdepositional sediment accumulation ( $\mathrm{pSA}$ ) at site $\mathrm{BS}$, allowing for dissolution of biogenic silica and decomposition of organic matter as it would occur in the sediment column:

$$
\mathrm{pSA}(\mathrm{mm} / \text { year })=\left[\begin{array}{c}
\text { F1ux } \\
\text { spec. density }
\end{array} \frac{100}{\text { Porosity }}-\text { Decompcorg }- \text { Disss } 1\right.
$$

For this calculation the same assumptions for porosity (\%), density $(\mathrm{g} / \mathrm{cm} 2)$, decomposition of organic carbon, and dissolution of biogenic silica are used that were applied for the conversion from postdepositional paleoflux to depositional paleoflux (Fig. 17; Table 3). This calculation has the advantage of showing the compositional changes in a core on a biweekly scale, which allows for a better assignments of seasons to the individual black and white laminae of the cores (see section 2.4.3.). 


\subsubsection{Chronology}

Some of the cores used from the $R / V$ CHAIN cruise had previously been varve-counted (Degens et a1., 1980) which led to a reassignment of ages for the anoxic history of the Black Sea. Degens et al. (1980) used unit

I in core 35 and unit II in core 18 since they were not interrupted by turbidites (Fig. 15). According to these ages, anoxic conditions (deposition of sediment unit II) began 5,100 years B.P., deposition of unit I began 1,000 years B.P.. Similarly, varve counting by Arkhangel'sky and Strakhov (1938) showed that salination of the Black Sea and with it onset of anoxic conditions started about 5,000 years ago.

The varve counts by Degens et al. (1980) were generally confirmed by separate sedimentation rate computations for unit I \& II from the varve counts of the individual sediment blocks. Given that the sedimentation rate of unit $I$ is on average $26 \mathrm{~cm} / 1,000$ years (Fig. 20) and the average thickness of unit I is about $29 \mathrm{~cm}$, the hypothetical transition between units I \& II calculated in this manner occurred at about 1,093 \pm 111 varve couplets ago (Table 4). By the same calculation, unit II has 4507 \pm 474 varve couplets, i.e. deposition of unit II began $5600 \pm 585$ years ago, assuming annul varve couplets. This time span is about $13 \%$ longer than the varve count by Degens et al. (1980); however, the years of my varve count from the blocks is based on only $27 \%$ of the entire unit II in core 18. 
Figure 20: Sedimentation rates for units I \& II for cores $5 \& 18$ as computed by dividing the average thickness of the sediment blocks used for the paleoflux study by their number of varve couplets. The average sedimentation rate for unit $I$ is 26 $\mathrm{cm} / 1,000$ years, for unit II $9 \mathrm{~cm} / 1,000$ years. 
Black Sea - Sedimentation rate

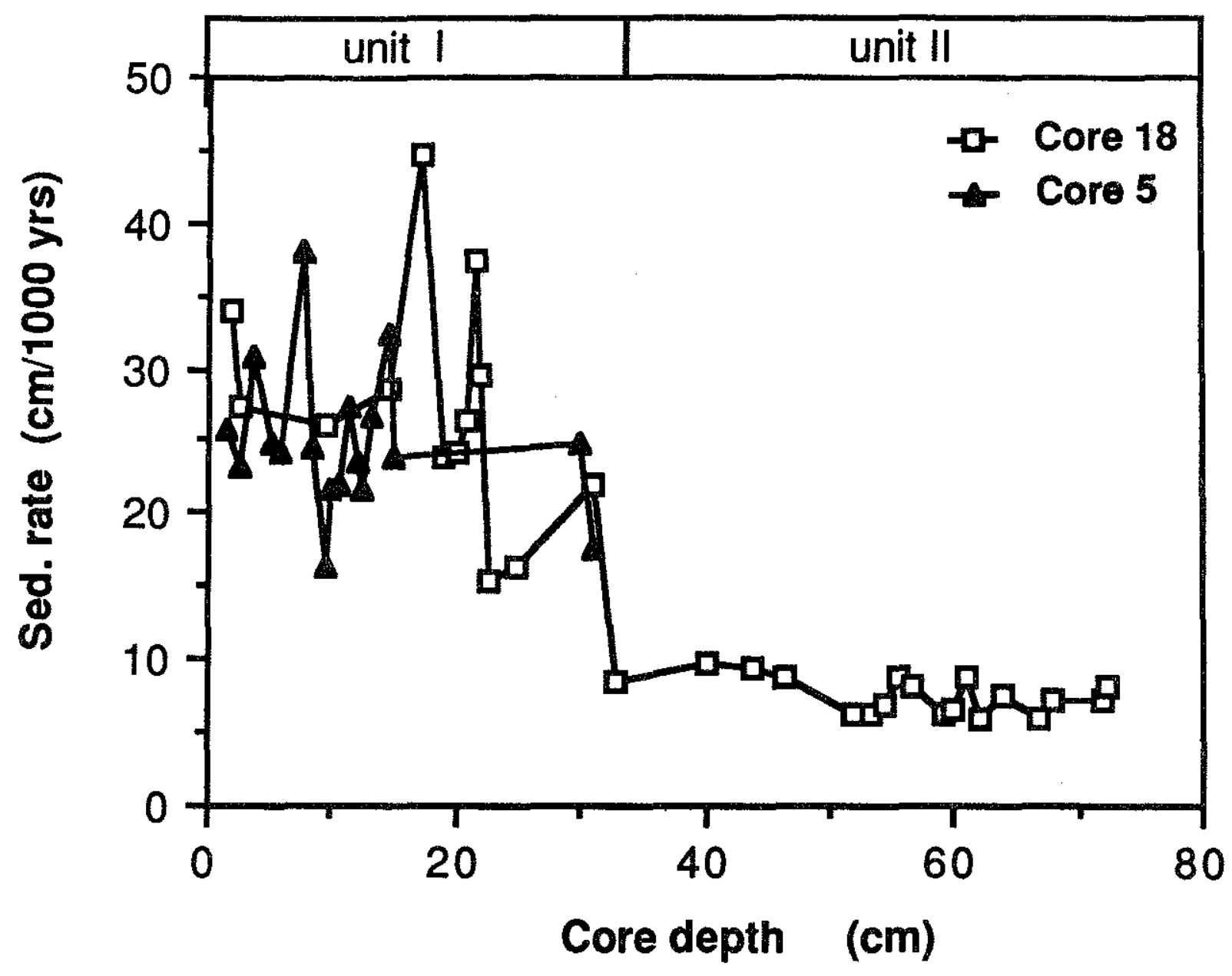


Table 4: Average age of the sediment units $I$ and II calculated by dividing the thickness of each sediment block by its number of varve couplets. The computed ages are within the range of the ages counted by Degens et al. (1980).

\begin{tabular}{|c|c|c|c|c|}
\hline Unit & $\begin{array}{l}\text { Aver } \\
\text { Core }\end{array}$ & of 18 & & \\
\hline $\begin{array}{l}\text { Average sed. rate } \\
\qquad(\mathrm{cm} / 1000 \text { yrs })\end{array}$ & $\begin{array}{r}\text { I } \\
\text { II }\end{array}$ & $\begin{array}{r}26.3 \\
8.9\end{array}$ & & $\begin{array}{l}(n=30) \\
(n=18)\end{array}$ \\
\hline $\begin{array}{l}\text { Sediment thickness } \\
(\mathrm{cm})\end{array}$ & $\begin{array}{r}\text { I } \\
\text { II }\end{array}$ & $\begin{array}{l}28.8 \\
41.0\end{array}$ & & $\begin{array}{l}(\text { cores } 5 \& 18) \\
(\text { core } 18)\end{array}$ \\
\hline $\begin{array}{r}\text { Hypothetical age } \\
\text { (years B.P.) }\end{array}$ & I & $\begin{array}{l}1093 \\
4507\end{array}$ & $\begin{array}{l} \pm 111 \\
\pm 474\end{array}$ & \\
\hline $\begin{array}{c}\text { Degens et al. }(1980) \\
\text { (years B.P.) }\end{array}$ & $\begin{array}{r}\text { I } \\
\text { II }\end{array}$ & $\begin{array}{r}998 \\
4085\end{array}$ & & \\
\hline
\end{tabular}


I consider it reasonable to assume one varve couplet to be an annual deposit for the following reasons:

(i) Distinct seasonality in particle flux. The sediment trap study showed that even at the comparatively complex sediment trap site BS near the coast, that the predominant supply of the major particle flux components alternate distinctly annually (chapter 1). Biogenic carbonate is supplied by primary production of coccolithophorids in summer and fall; terrigenous matter is supplied by rivers during peak river discharge in winter and spring. White laminae are composed almost exclusively of the coccolithophorid species Emiliania huxleyi; black laminae are composed of mostly clay minerals.

(ii) Carbon-14 dating. Carbon-14 dating of cores from the R/V ATLANTIS II cruise in 1969 , utilizing both organic matter and carbonate, had yielded ages of about $3,090 \pm 140$ and $7,090 \pm 180$ years (Ross and Degens, 1974). These ages are too old, however, due to mixing of authigenic Black Sea particles with terrigenous carbonate and organic carbon supplied by river and by reworking of material from the continental shelf (Bukry, 1974). Degens et al. (1980) suggested that the particulate matter already had an "age" of about 2,000 years at the time of deposition. This offset was confirmed by Calvert (1987) who measured ${ }^{14} \mathrm{C}$ in the core top of core 1432 collected during the $\mathrm{R} / \mathrm{V}$ ATLANTIS II cruise in 1969, the location coinciding with R/V CHAIN site 18. 
However, it is not possible to say with definite certainty that the varve count is the precise absolute age. Possible sources of error are:

(i) Multiple varve couplets per year: Multiple couplets per year are not considered common occurrences, however, since they would increase the ages. For example, even though the ${ }^{14} \mathrm{C}$ ages by Ross and Degens (1974) were 2,000 years older than the varve count by Degens et al. (1980), the length of time during which unit II was deposited is in both cases about 4,000 years.

(ii) Missing varves: Varves could be missing because the coccolithophorid bloom may not be occurring in certain years. At least during the $21 / 2$ year long sediment trap study this occurrence was not observed, however.

(iii) Alteration within fluff layer: If the laminae entirely reflect seasonal processes supplying particles, the particles have to pass through the fluff layer without disturbance or repackaging. Possible disturbances include chemical alteration of the particles and differential settling of the particles due to different size and density. The impact of the fluff layer as a filter on seasonal particle supply is not known at present, but not considered important for the chronology since little chemical alteration is expected for the main components of the laminae, biogenic carbonate and lithogenic matter. 
Although it is not absolutely certain at this point that the varve counted age represents the true age, I consider the varve counted ages by Degens et al. (1980) the presently most reasonable ages available and will therefore adopt these ages in this study.

\subsection{RESULTS}

2.4.1. Paleoflux in unit I

In unit $I$, the average composition of the major components is $65 \%$ $\mathrm{CaCO}_{3}, 27 \%$ noncombustible matter, and $4.1 \%$ organic carbon (Table 5). Most of the carbonate consists of coccoliths, Emiliania huxleyi (Fig. 14a; Bukry et al., 1970; Miiller and Stoffers, 1974; Degens and Stoffers, 1980). The carbonate is concentrated in the white laminae.

The average total postdepositional paleoflux ( $\mathrm{PPF}$ ) for unit $I$ in cores $5 \& 18$ was $437 \mathrm{mg} \mathrm{m}$ m $^{-2}$ day $^{-1}$ (Fig. 21; Table 5). It was $14 \%$ higher in core 5 than in core 18. While the carbonate and organic carbon $\mathrm{PPF}$ in both cores are similar, the noncombustible $\mathrm{PPF}$ is considerably higher in core 18 than in core 5 .

The total pPF and carbonate pPF are significantly correlated for both cores $5 \& 18$ (Fig. 22; Table 6). In contrast, the noncombustible 
Figure 21: Postdepositional paleoflux (pPF) at core sites 5, 18, and 35 throughout the anoxic history of the Black Sea for the total, carbonate, noncombustible, and organic carbon pPF. The absolute ages assigned to the data are based on the varve count by Degens et al. (1980). Marked also with a black triangle on the upper, horizontal axis for comparison is the annual mean of the present-day particle flux and its components averaged from the $250 \mathrm{~m}$ and $1,200 \mathrm{~m}$ sediment trap (see chapter 1). 


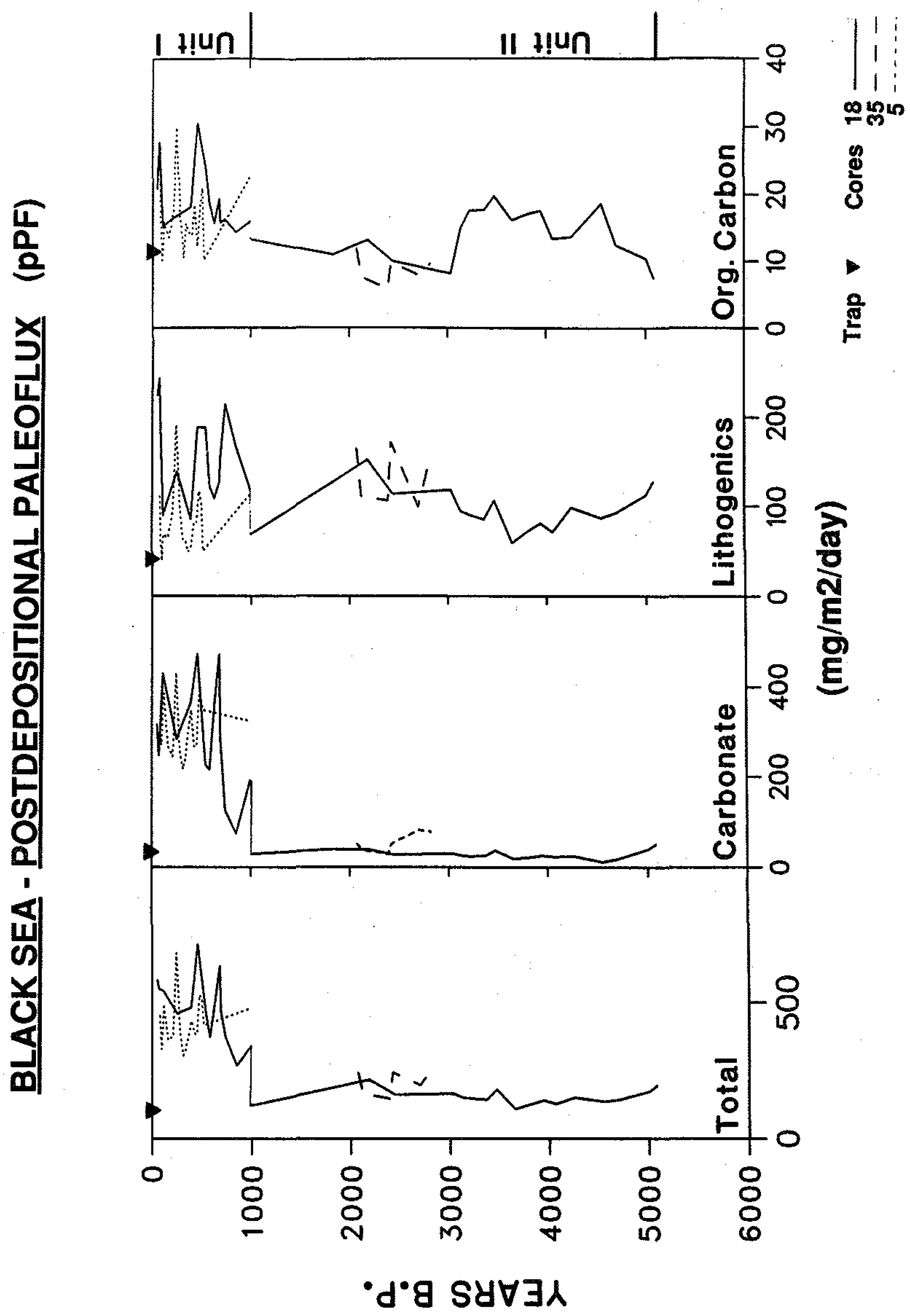


Figure 22: (a) Total postdepositional paleoflux (pPF) versus carbonate pPF in Black Sea sediment cores 5, 18, and 35 from 56 samples of sediment units $I$ and II. The slopes of regression lines for unit $I$ in cores $5 \& 18$ are nearly equal but the relative concentration of carbonate in core 5 is on average $15 \%$ higher than in core 18 (Table 3 ).

(b) Total postdepositional paleoflux (pPF) versus the noncombustible pPF from the same cores. The noncombustible fraction is composed of over $95 \%$ terrigenous matter, with the remaining fraction composed of biogenic silica.

(c) Total postdepositional paleoflux ( $\mathrm{PPF}$ ) versus the organic carbon pPF from the same cores. 


\section{BLACK SEA - POSTDEPOSITIONAL PALEOFLUX}

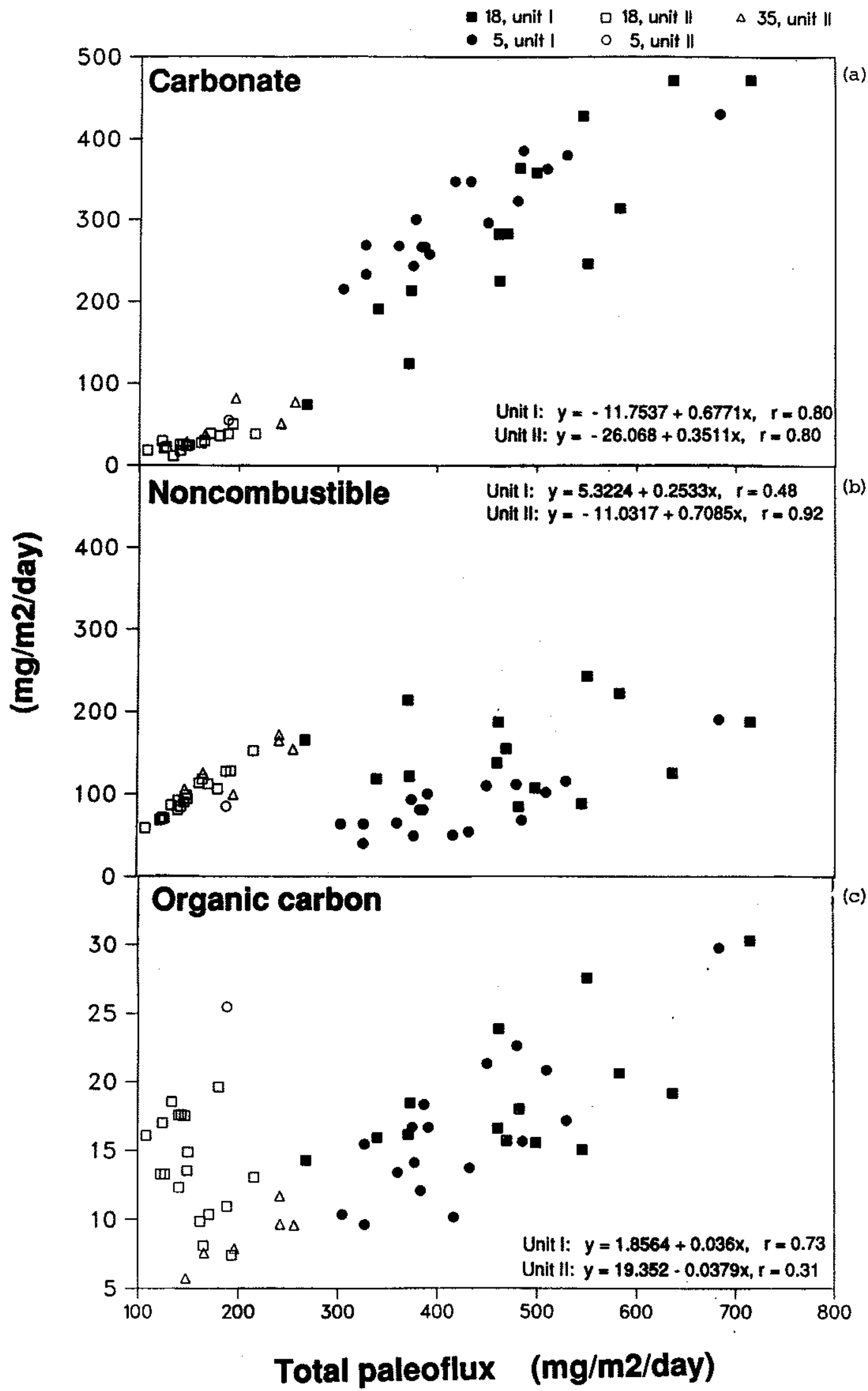


Table 5: Postdepositional paleoflux ( $\mathrm{pPF}$ ) in cores 5, 18, and 35. (The postdepositional paleoflux represents the paleoflux uncorrected for the dissolution of silica and the decomposition of organic matter.)

\begin{tabular}{|c|c|c|c|c|c|c|c|c|c|}
\hline & \multirow{2}{*}{$\begin{array}{l}\text { PARTICLE FLUX } \\
\text { Average of } \\
\text { sediment } \\
\text { traps }\end{array}$} & \multirow[b]{2}{*}{ Core 5} & \multicolumn{5}{|c|}{ POSTDEPOSITIONAL PALEOFLUX ( $\mathrm{pPF}$ ) } & \multirow{2}{*}{\multicolumn{2}{|c|}{$\begin{array}{l}\text { Ratio } \\
\text { (Unit I/ } \text { Unit II } \\
\text { Traps } \\
\text { Traps) }\end{array}$}} \\
\hline & & & $\begin{array}{l}\text { Unit I } \\
\text { Core } 18\end{array}$ & $\begin{array}{l}\text { Core } 5 \& 18 \\
\text { (average) }\end{array}$ & Core 35 & Core 18 & Core 35 & & \\
\hline \multicolumn{10}{|l|}{ (a) mg/a2/day } \\
\hline $\begin{array}{l}\text { TOTAL FLUX } \\
\text { CARRONATE } \\
\text { NONCOMBUSTIBLE } \\
\text { ORG. CARBON }\end{array}$ & $\begin{array}{l}95.4 \\
26.9 \\
41.3 \\
11.9\end{array}$ & $\begin{array}{r}467.2 \\
273.8 \\
154.2 \\
19.1\end{array}$ & $\begin{array}{r}411.2 \\
292.0 \\
84.4 \\
16.3\end{array}$ & $\begin{array}{r}436.5 \\
283.8 \\
115.9 \\
17.6\end{array}$ & $\begin{array}{ll} & \mathbf{d} \\
\mathbf{n} & \mathbf{a} \\
\mathbf{0} & \mathbf{t} \\
& \mathbf{a}\end{array}$ & $\begin{array}{r}151.8 \\
25.7 \\
96.4 \\
14.5\end{array}$ & $\begin{array}{r}204.0 \\
50.4 \\
133.8 \\
8.7\end{array}$ & $\begin{array}{r}4.6 \\
10.6 \\
2.8 \\
1.5\end{array}$ & $\begin{array}{l}1.6 \\
1.0 \\
2.3 \\
1.2\end{array}$ \\
\hline \multicolumn{10}{|c|}{ (b) Percent of total fiux } \\
\hline $\begin{array}{l}\text { CARBONATE } \\
\text { NONCOMBUSTIBLE } \\
\text { ORG. CARBON } \\
\qquad 4.27\end{array}$ & $\begin{array}{l}28.2 \\
43.6 \\
12.4 \\
\end{array}$ & $\begin{array}{l}56.4 \\
35.0 \\
4.2 \\
95.6\end{array}$ & $\begin{array}{r}71.5 \\
20.1 \\
\frac{3.7}{95.3 x}\end{array}$ & $\begin{array}{l}64.7 \\
26.8 \\
4.1 \\
95.67\end{array}$ & $\begin{array}{l}32.87 \\
61.88 \\
2.74^{*} \\
97.49 \%\end{array}$ & $\begin{array}{l}16.5 \\
63.1 \\
10.0 \\
89.6 \%\end{array}$ & $\begin{array}{r}24.5 \\
65.8 \\
4.3 \\
94.6 \%\end{array}$ & & \\
\hline \# of samples $(\mathfrak{n})$ & & 17 & 14 & 31 & 9 & 18 & 6 & & \\
\hline
\end{tabular}

- Determined from only 3 values 
Table 6: Correlation coefficients of the major paleoflux components for cores 5, 18, and 35 for unit I and II.

\begin{tabular}{|c|c|c|c|c|c|}
\hline \multirow[t]{2}{*}{ CORRELATION } & \multirow[b]{2}{*}{ Core 5} & \multicolumn{2}{|l|}{ UNIT I } & \multicolumn{2}{|c|}{ UNIT II } \\
\hline & & Core 18 & $\begin{array}{l}\text { Cores } 5 \& 18 \\
\text { (average) }\end{array}$ & Core 18 & Core 35 \\
\hline $\begin{array}{l}\text { Carbonate vs Total } \\
\text { Noncombustible vs Total } \\
\text { Corg vs Total }\end{array}$ & $\begin{array}{l}0.89 \\
0.82 \\
0.81\end{array}$ & $\begin{array}{l}0.88 \\
0.14 \\
0.64\end{array}$ & $\begin{array}{l}0.80 \\
0.48 \\
0.73\end{array}$ & $\begin{array}{r}0.79 \\
0.97 \\
-0.44\end{array}$ & $\begin{array}{l}0.56 \\
0.87 \\
0.88\end{array}$ \\
\hline $\begin{array}{l}\text { Noncomb. vs Carbonate } \\
\text { Corg vs Carbonate }\end{array}$ & $\begin{array}{l}0.48 \\
0.50\end{array}$ & $\begin{array}{r}-0.35 \\
0.31\end{array}$ & $\begin{array}{r}-0.14 \\
0.31\end{array}$ & $\begin{array}{r}0.71 \\
-0.58\end{array}$ & $\begin{array}{l}0.08 \\
0.33\end{array}$ \\
\hline Corg vs Noncombustible & 0.91 & 0.57 & 0.71 & -0.55 & 0.84 \\
\hline \# of samples (n) & 17 & 14 & 31 & 18 & 6 \\
\hline $\begin{array}{l}\text { Levels of significance } \\
<0.001 \\
<0.01 \\
<0.02 \\
<0.05 \\
<0.1\end{array}$ & $\begin{array}{l}\text { for } g i \\
0.69 \\
0.57 \\
0.53 \\
0.46 \\
0.39\end{array}$ & $\begin{array}{l}\text { en \# of sa } \\
0.74 \\
0.62 \\
0.57 \\
0.50 \\
0.43\end{array}$ & $\begin{array}{l}\text { mples (n) } \\
0.55 \\
0.44 \\
0.40 \\
0.34 \\
0.29\end{array}$ & $\begin{array}{l}0.68 \\
0.56 \\
0.52 \\
0.44 \\
0.38\end{array}$ & $\begin{array}{l}0.92 \\
0.83 \\
0.79 \\
0.71 \\
0.62\end{array}$ \\
\hline
\end{tabular}


pPF is only significantly correlated with the total pPF in core $5(r=$ 0.82 ); in core 18 it is not significantly correlated ( $r=0.14$; Table 6). These results indicate that the variations in the total PPF are mainly caused by variations in the carbonate PPF. The noncombustible matter appears to have the same source area as the carbonate in core 5 , whereas it is different in core 18 (see discussion in section 2.5.2.).

The organic carbon $\mathrm{pPF}$ is similar for both deep basin cores. Correlation between organic carbon $\mathrm{PPF}$ and total $\mathrm{PPF}$ is significant in both cores (Table 6). The lower correlation coefficients between organic carbon $\mathrm{pPF}$ and carbonate $\mathrm{pPF}$ than between organic $\mathrm{pPF}$ and noncombustible PPF suggests that a considerable fraction of the carbonate is derived by resuspension from the Danube shelf after aerobic degradation of the organic matter of the coccolithophorids. Organic carbon content of one white band was only $1 \%$ compared to an average of $4 \%$ for unit $I$.

\subsubsection{Paleof 1 ux in unit II}

In unit II, the average composition is $17 \%$ carbonate, $63 \%$ noncombustible matter, and $10 \%$ organic carbon (Table 5). Thus, in contrast to unit I, unit II is dominated by sedimentation of lithogenic material. It also has a considerably higher organic carbon content, which is why this unit has been called a sapropel (e.g. Ross and Degens, 
1974). The comparison between the major sediment components (carbonate and lithogenics) shows that both the individual black and white laminae in unit II are dominantly composed of 1 ithogenic material, similar to the black laminae in unit I (Fig. 23). The difference in color between the laminae in unit II may be related to variations in the organic matter content.

The average total postdepositional paleoflux ( $P P F)$ for unit II in core 18 is lower by a factor of 3 compared to unit I (Fig. 21; Table 5) whereas the carbonate $\mathrm{PPF}$ is lower by a factor of 11 . The noncombustible PPF in core 18 is only $17 \%$ lower than in unit $\mathrm{I}$, indicating little variation in the terrigenous input over the last 5,000 years. The organic carbon PPF in the deep basin cores is $18 \%$ lower than in unit $I$.

The significant correlation between noncombustible pPF and total pPF in core 18 (Table 6) indicates that variability in total pPF is dominantly caused by changes in terrestrial particle supply, which ranges in unit I between 50 and $200 \mathrm{mg} \mathrm{m} \mathrm{m}^{-2} \mathrm{day}^{-1}$ (Fig. 22). The significant correlation between the carbonate and the noncombustible pPF for core 18 in unit II $(r=0.71)$ indicates a terrigenous source for carbonate. Terrigenous supply of carbonate is conceivable as there did not exist an important source of biogenic carbonate during deposition of unit II. 
On the slope (core 35) the total pPF is $25 \%$ higher than in the deep basin core 18. Both the carbonate and noncombustible fractions are relatively higher on the slope than in the deep basin. The organic carbon content on the slope averages only $2.7 \%$ (Table 5).

\subsubsection{Comparison between present-day particle flux and paleoflux}

The present biochemical conditions in the Black Sea became established only about 1,000 years ago. Specifically, the most important changes that occurred about 1,000 years ago included (a) the firm establishment of the cosmopolitan coccolithophorid Emiliania huxleyi in the Black Sea, and (b) the rise of the $\mathrm{H}_{2} \mathrm{~S} / \mathrm{O}_{2}$ interface to a shallow depth (Deuser, 1974), reducing the time of aerobic decomposition in the water column when biogenic particles settle. We will therefore compare the present-day particle flux to the depositional paleoflux $(\mathrm{dPF})$, converted from the postdepositional paleoflux, for only unit I.

For the assignment of seasons to the individual black and white laminae of the cores, i.e. 1ink the seasonal dynamics of the biogenic and 1ithogenic particle supply at site BS to the timing of the deposition of the black and white laminae in the cores, the annual particle flux was converted into postdepositional sediment accumulation, as described in section 3.2.3. For this calculation, the annual 
particle flux record (sediment trap) was converted into a short high-resolution core section for the two-year deposition period (Fig. 24), thereby showing the compositional changes in a core on a biweekly scale, which allows for a better assignments of seasons to the individual laminae of the basin floor sediments in the Black Sea (section 2.4 .3 .2$)$.

\subsubsection{Regional variability}

The comparison between the present-day particle flux and the depositional paleoflux (cores $5 \& 18$, unit I) reflects the importance of regional variability, even though the two core sites are only $100-150 \mathrm{~km}$ north/northeast of the sediment trap site. The total dPF in cores $5 \&$ 18 is on average 5.5 times higher than in the traps (Table 7). However, these differences are not uniform for the individual major chemical components. Most of the higher dPF is caused by the 11 times higher carbonate dPF. The noncombustible dPF is only about 3 times higher, the organic carbon dPF about 5 times higher (using the $70 \%$ decomposition correction value).

The higher $\mathrm{dPF}$ in the cores is also reflected in the calculation of the postdepositional sediment accumulation from the particle flux at site BS. Over the $21 / 2$ year sampling period the sediment accumulation would be $55 \mu \mathrm{m}$ from the $250 \mathrm{~m}$ trap and $58 \mu \mathrm{m}$ from the 1,200 $\mathrm{m}$ trap. 
Table 7: Depositional paleoflux (dPF) in cores 5, 18, and 35. (The depositional paleoflux represents the postdepositional paleoflux (pPF) corrected for the dissolution of silica and the decomposition of organic matter.)

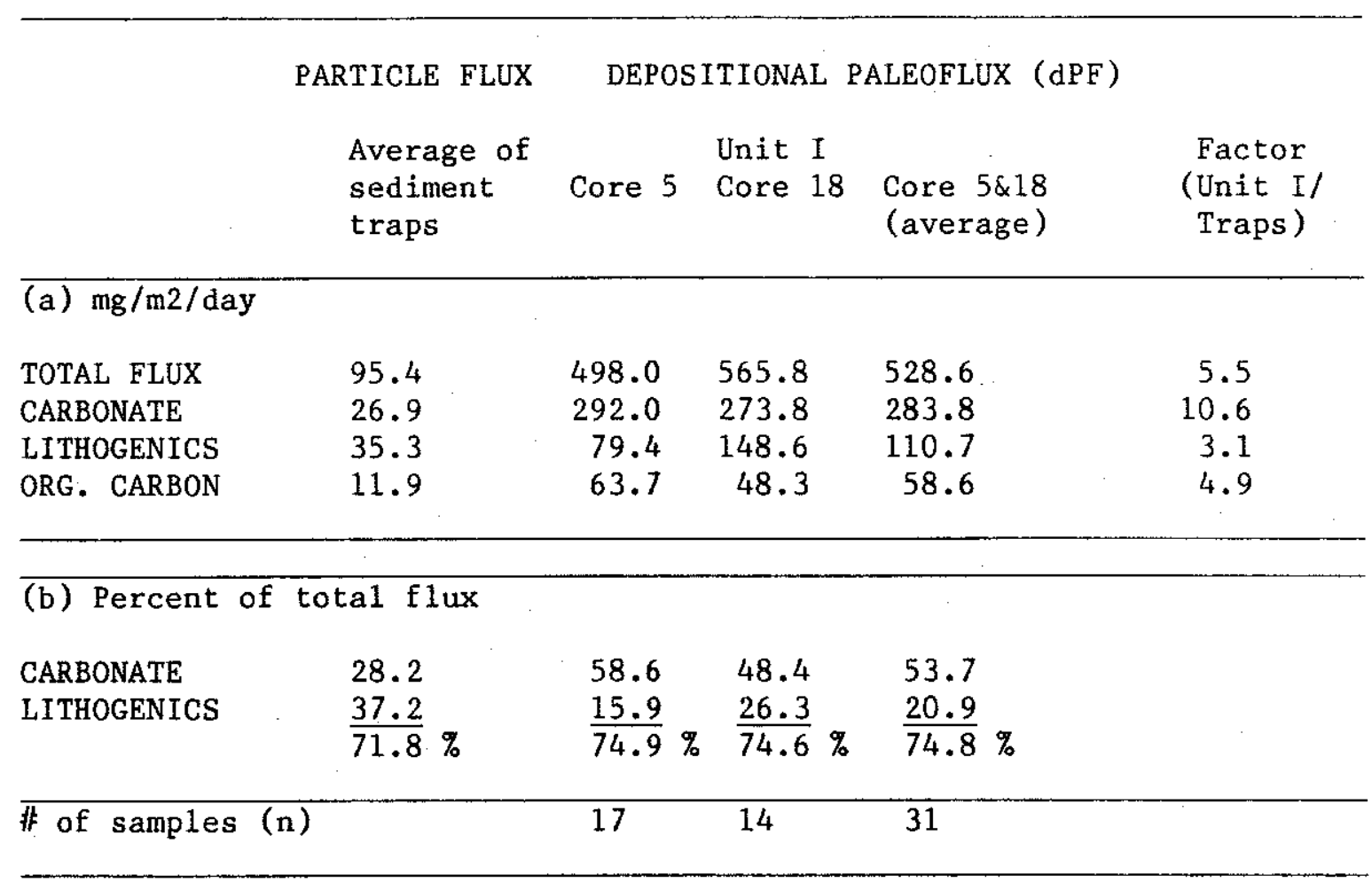


The average thickness of one varve couplet in unit I in the deep basin cores is $263 \mu \mathrm{m}$. Thus, based on this calculation the annual deposition at the core sites is on average 4.7 times higher than at site BS.

\subsubsection{Seasonal variability}

The two major chemical components in the particulate matter of site BS are carbonate and lithogenic matter as in the core sediments (Fig. 23). The calculation of the postdepositional sediment accumulation at site BS shows that the lithogenic content is clearly dominant from February to May (Phase III) with a $49 \%$ higher contribution than for the time period between June and January (Phases I \& II) (Fig. 24). During Phases I \& II, the relative carbonate and lithogenic contents are about equal in concentration (Fig. 23). At site BS, Phase I would account for the deposition of $46 \%$ of the annual sediment deposition that would ultimately be buried, Phase II for $28 \%$, and Phase III for $26 \%$.

In unit I in the cores, the average carbonate content of four individual white laminae using the microprobe was $95 \%$; bulk chemical analyses of one thick white band showed a $93 \%$ carbonate content (Fig. 25). The organic carbon content of this band was $1 \%$. The black laminae are dominantly composed of terrigenous material. The ratio of carbonate to noncombustible material by microprobe analysis was about 


\section{$-112-$}

Figure 23: Relative composition of the major particle flux components carbonate and lithogenics for the annual particle flux at site BS, the individual laminae in the deep basin cores, and the relevant river in the western Black Sea. Data for the Danube were taken from Shimkus and Trimonis (1974). 


\section{$\%$ Carbonate}

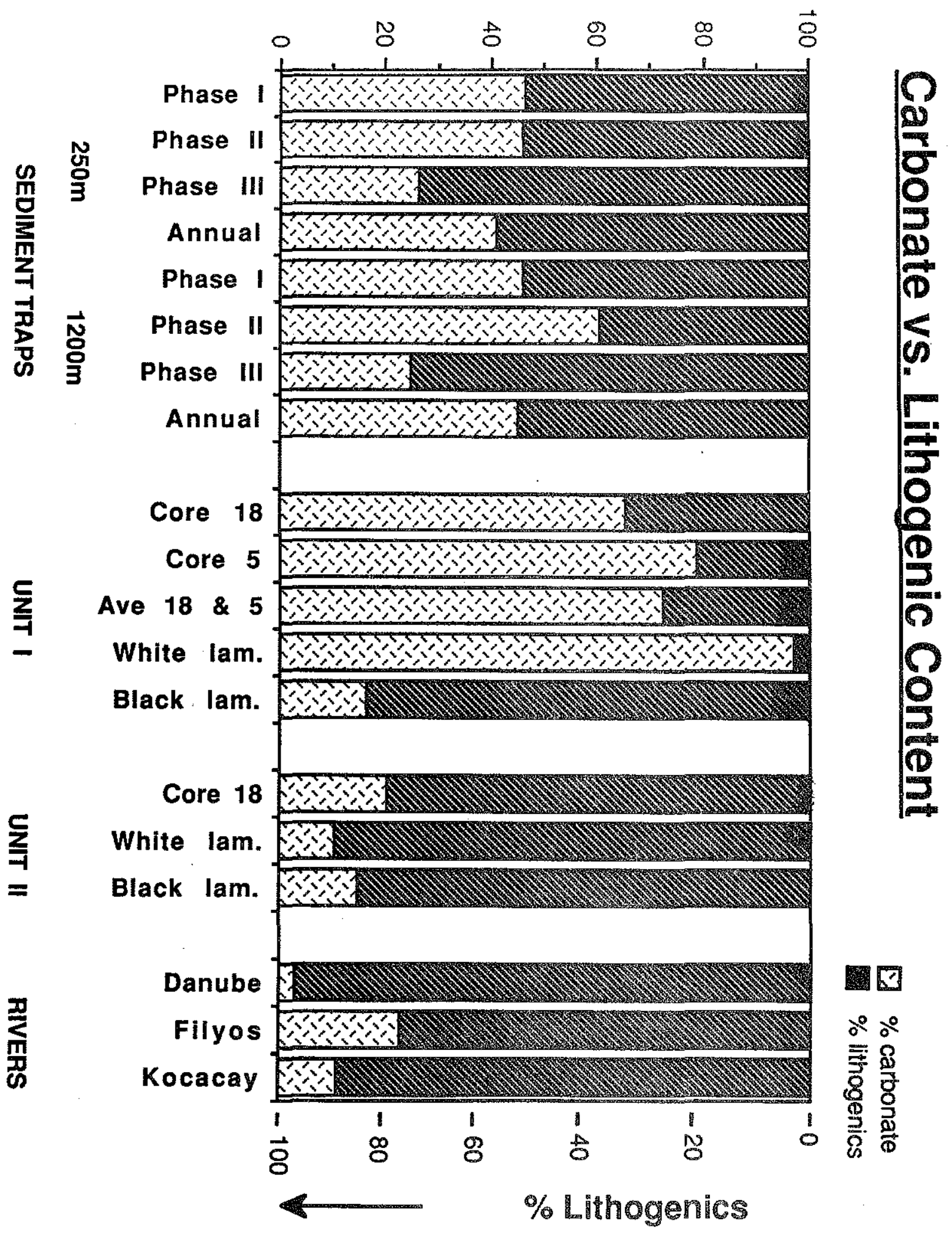


Figure 24: Postdepositional sediment accumulation based on the particle flux in the $1,200 \mathrm{~m}$ sediment trap at site BS. This figure represents the $21 / 2$ year long particle flux record at sediment trap site BS, converted into a hypothetical core section after decomposition of organic matter and dissolution of biogenic silica has taken place. Most of the accumulated sediment consists of carbonate and lithogenic particles. 


\section{POSTDEPOSITIONAL ACCUMULATION}

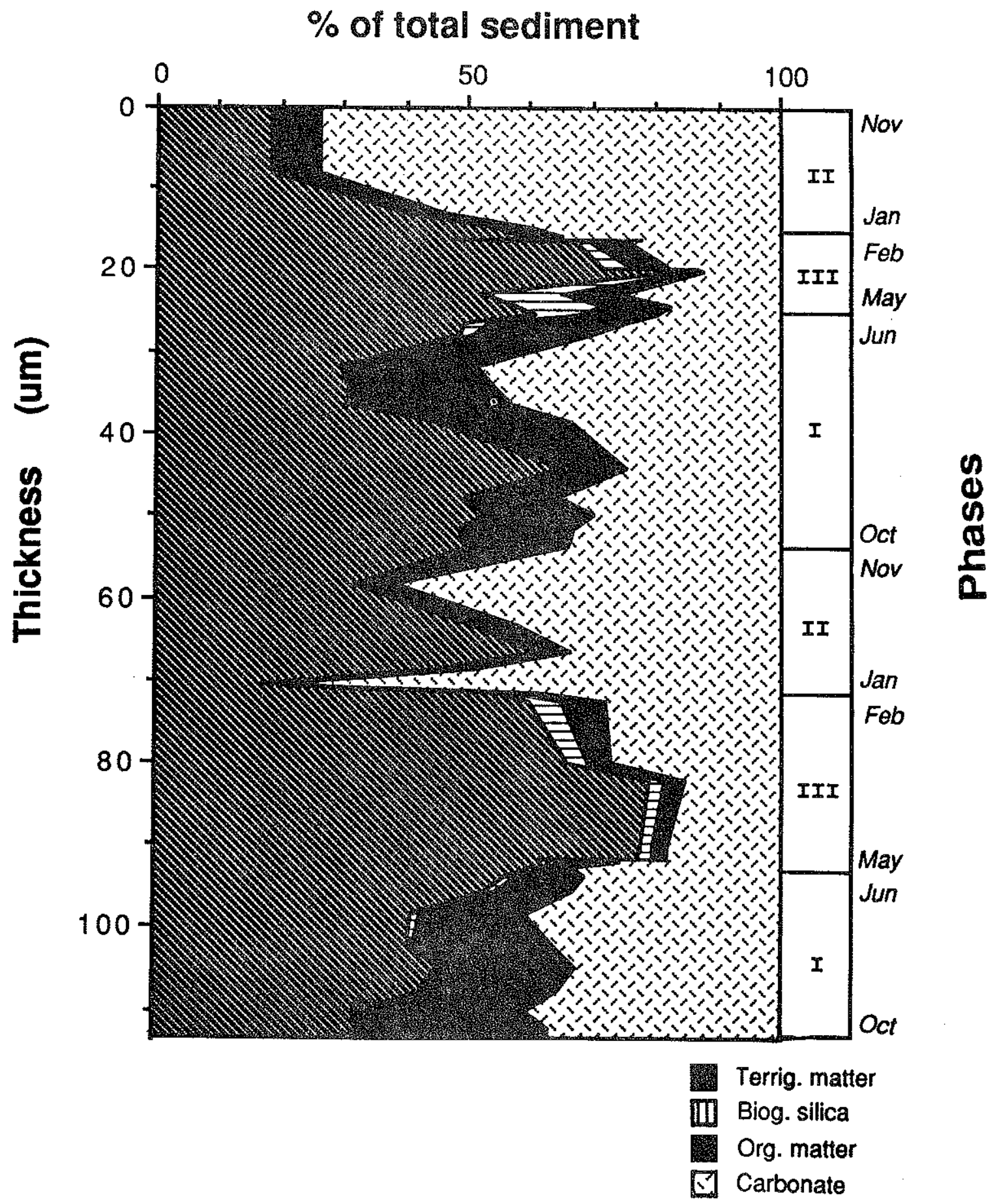




\title{
$-116-$
}

\author{
Figure 25: Semi-quantitative determination of the major element \\ concentrations of black laminae (a) and white laminae (b) \\ using an EDX electron microprobe. (a) and (b) are the result \\ of $5 \times 200 \mu \mathrm{m}$ area scan vertical to the laminae (about 600 \\ years B.P.) on epoxy impregnated polished sample.
}



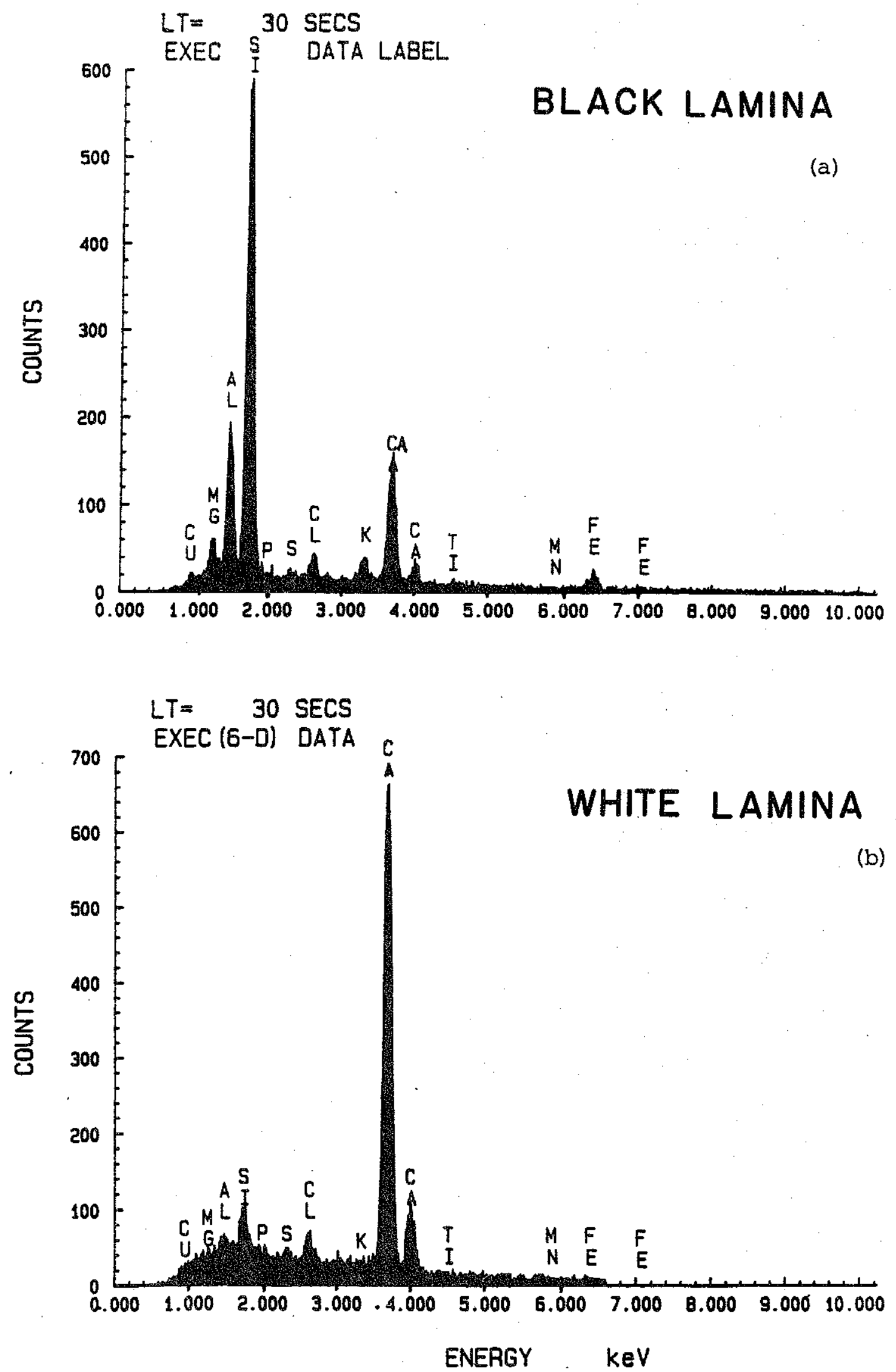
1:5 (Fig. 23). This ratio represents a relatively higher contribution of carbonate than found in the terrigenous input of the rivers that drain into the northwestern Black Sea, including the Danube (Fig. 23).

Although the paleoflux of particulate components is higher in the central western Black Sea than at the trap site, seasonal processes relevant in the supply of the particles are considered similar at both sites. Comparison between the seasonal variability in the composition of the particle flux (Fig. 24) and the composition of the black and white laminae suggests that black laminae formed approximately between February and June and white laminae from July to January.

\subsection{PARTICLE FLUX IN THE BLACK SEA - DISCUSSION}

\subsubsection{Particle flux through time}

The biochemical changes that occurred in the Black Sea during its anoxic history $(0-5,000$ years B.P. ) are reflected in the paleof 1 ux. From 5,000 to 1,000 years B.P. (unit II) the total paleoflux was comparatively constant even though the higher organic carbon paleoflux suggests higher primary productivity during the early part of unit II $(5,000-3,000$ years B.P.); the 1ithogenic paleoflux during that time

period is lowest indicating that the higher organic carbon paleoflux could not be explained by higher input of terrigenous carbon. Higher 
productivity is also indicated by data from Glenn and Arthur (1985). At 1,000 B.P. the total paleoflux increased rapidly by a factor of 3 when salinity rose to a level acceptable to Emiliania huxleyi. The lowest salinity at which Emiliania huxleyi survives $\left(11 \%_{0}\right)$ was reported in the Sea of Azov by Bukry (1974). The production of coccolithophorids increased the carbonate paleoflux by a factor of 11 at the transition from unit I to unit II at 1,000 years B.P.. In contrast, the organic carbon and lithogenic paleoflux in unit $I$ in the deep basin cores $5 \& 18$ remained at a similar level as in the previous 4,000 years, indicating that the abrupt increase in total paleoflux was caused primarily by an increase in the supply of Emiliania huxleyi. Variations in river input probably contributed more substantially to the paleoflux on the slope (core 35 ) in unit I where the terrigenous matter supply from the Danube was probably relatively high as it is today.

The organic carbon paleoflux of the last 1,000 years equals the paleoflux at the beginning of anoxic conditions 5,000 years B.P.. The lower 1ithogenic fraction between 5,000 and 3,000 years B.P., at a time when the organic carbon paleoflux is relatively high, suggests that a higher percentage of the organic carbon during that time period was supplied by primary production, assuming the terrigenous organic carbon content in rivers remained constant. Relatively higher contribution of marine organic carbon compared to terrigenous organic carbon is also suggested by $\delta^{13} \mathrm{C}$ data from Deuser (1972) and Calvert and Fontugne (1987) who showed highest values during this time period. Thus, primary 
production was probably higher during the first 2,000 years of anoxic conditions in the Black Sea, as also suggested by Glenn and Arthur (1985), then declined between 3,000 and 1,000 B.P., and increased again after 1,000 B.P., concurrent with the introduction of Emiliania huxleyi.

\subsubsection{Regiona1 variability}

The contrast between present-day particle flux at site BS and paleoflux at sites $5 \& 18$ reflects considerable variability in hemipelagic deposition in the Black Sea. This variability is also reflected in the different composition of surface sediments (Miiller and Stoffers, 1974; Shimkus and Trimonis, 1974). The hemipelagic deposition in any given region is essentially a result of the relative importance of the supply of riverine and biogenic particles, dispersed regionally by currents and during storms (chapter 1). Riverine particle supply dominates the sedimentation along the broad fringes of the Black Sea as indicated by the high lithogenic contents in the sediment.

While the eastern Black Sea today is presently dominated by river input from the Anatolian mountains and the Caucasus (Shimkus and Trimonis, 1974), sedimentation in most of the western Black Sea is controlled by the particle supply from the northwestern Black Sea (see chapter 3). Rivers that currently drain into the northwestern area (Danube, Dnepr, Bug, and Dnestr) provide $59 \%$ of the detrital input to 
the Black Sea and about $75 \%$ of the dissolved salts and nutrients (Shimkus and Trimonis, 1974). Biological production is considerably higher over the Danube shelf (Shimkus and Trimonis, 1974) than at the trap site BS. The shallow water depth of the northwestern region and the texture of the shelf sediments (Miller and Stoffers, 1974) suggest that a large portion of the biogenic particles are transported of $f$ shelf to be deposited on the abyssal plain. In the central regions of the Black Sea biogenic carbonate is the dominating particle source.

Regional variability in particle supply is even apparent within the relatively closely spaced core sites $5 \& 18$ in unit $I$. The average carbonate paleoflux in core 5 is $15 \%$ higher than in core 18 , whereas the noncombustible paleoflux in core 5 is about $50 \%$ lower than in core 18. While the correlation between the total paleoflux and the carbonate paleoflux in both cores is significant, correlation between the total paleoflux and the noncombustible paleoflux is significant only in core 5. At core site 5 the supply of carbonate may be higher due to the proximity of the productive northwestern shelf region (Shimkus and Trimonis, 1974).

\subsubsection{Seasonal variability}

The seasonal contrast between the major flux components, lithogenics and carbonate is not as pronounced in the sediment trap record as in the 
laminated cores. This contrast has to be related to the different supply of these materials, since they both remain unaltered after deposition. Comparison of the relative carbonate and 1ithogenic concentration for the individual laminae (Fig. 23) shows that the carbonate content is considerably higher in the white bands in the cores than from June to January (Phases I \& II) in the sediment trap; the lithogenic content is considerably higher in the black bands in the cores than from February to May (Phase III) in the sediment trap. This indicates that not only the total particle supply from the northwestern Black Sea is considerably higher, but also the seasonal contrast between the major components, carbonate and lithogenics, is more distinct. The relatively lower carbonate content in the black laminae (cores) compared to Phase III (sediment trap) may be a result of the lower terrigenous carbonate content in the Danube compared to the Turkish rivers (Shimkus and Trimonis, 1974).

The timing of deposition of black and white laminae can be estimated for sediment trap site BS, but cannot be established with absolute certainty for the entire Black Sea, due to insufficient recent biological data from other parts of the Black Sea. Earlier works for the western Black Sea include the studies by Belogorskaya (1959), who reported highest coccolithophorid concentrations in the northwestern Black Sea in spring, and Kovaleva (1969) who reports highest coccolithophorid concentrations in the Bay of Sevastopol from February to April. Reliable time-series data on the annual primary production in 
the Black Sea, however, appear to be lacking (Sorokin, 1982), especially for the central Black Sea. If we assume similar seasonal phytoplankton dynamics in the central and northwestern areas of the western Black Sea as at the sediment trap site BS, the deposition of the white bands occurs during Phases I\& II. In Phase I (June to October), the particle supply at site BS consists dominantly of coccoliths, which may also be true for the central and northern parts of the western Black Sea. A Coastal Zone Color Scanner (CZCS) satellite image shows a massive phytoplankton bloom (Holligan, 1983; Holligan, 1987, pers, comm.) in these areas on October 7, 1980 (Fig. 26). With the onset of the storms in November, resuspension of shelf deposits becomes a dominant process in the supply of particles, as also observed in the East China Sea (Milliman et a1., 1985a; Milliman et a1., 1985b). The relative carbonate content in the white laminae or the particle supply in Phases I \& II will depend on the relative importance of local supply of biogenic carbonate versus the proximity of the depositional site to a source of lithogenic particles. The relatively high productivity of the northwestern Black Sea may explain the relatively high carbonate content in the white bands in the deep basin cores.

Based on the particle supply at the southwestern Black Sea, the deposition of the black laminae in the cores coincides approximately with the particle flux between February and May (Phase III) in the sediment trap. (Fig, 27). Phase III is the time period of highest river discharge for the Danube (UNESCO, 1978), as we11 as for the Turkish 
Figure 26: Coastal Zone Color Scanner (CZCS) image (channel 3) of the entire Black Sea from October 7, 1980. The higher spectra1 reflectance in the northwestern and western B1ack Sea indicates a phytoplankton bloom, possibly a bloom of the coccolithophorid species Emiliania huxleyi. (The 1ighter areas in the southern Black Sea are cloud fields.) 





Figure 27: Temporal relationship between the depositional phases observed in the present-day particle flux at site BS, and the resulting black and white laminae in the sediment record, based on the understanding of the temporal dynamics of the biogenic and lithogenic particle supply in the southwestern Black Sea (chapter 1). Temporal differences in the particle supply dynamics in other parts of the Black Sea may vary. 


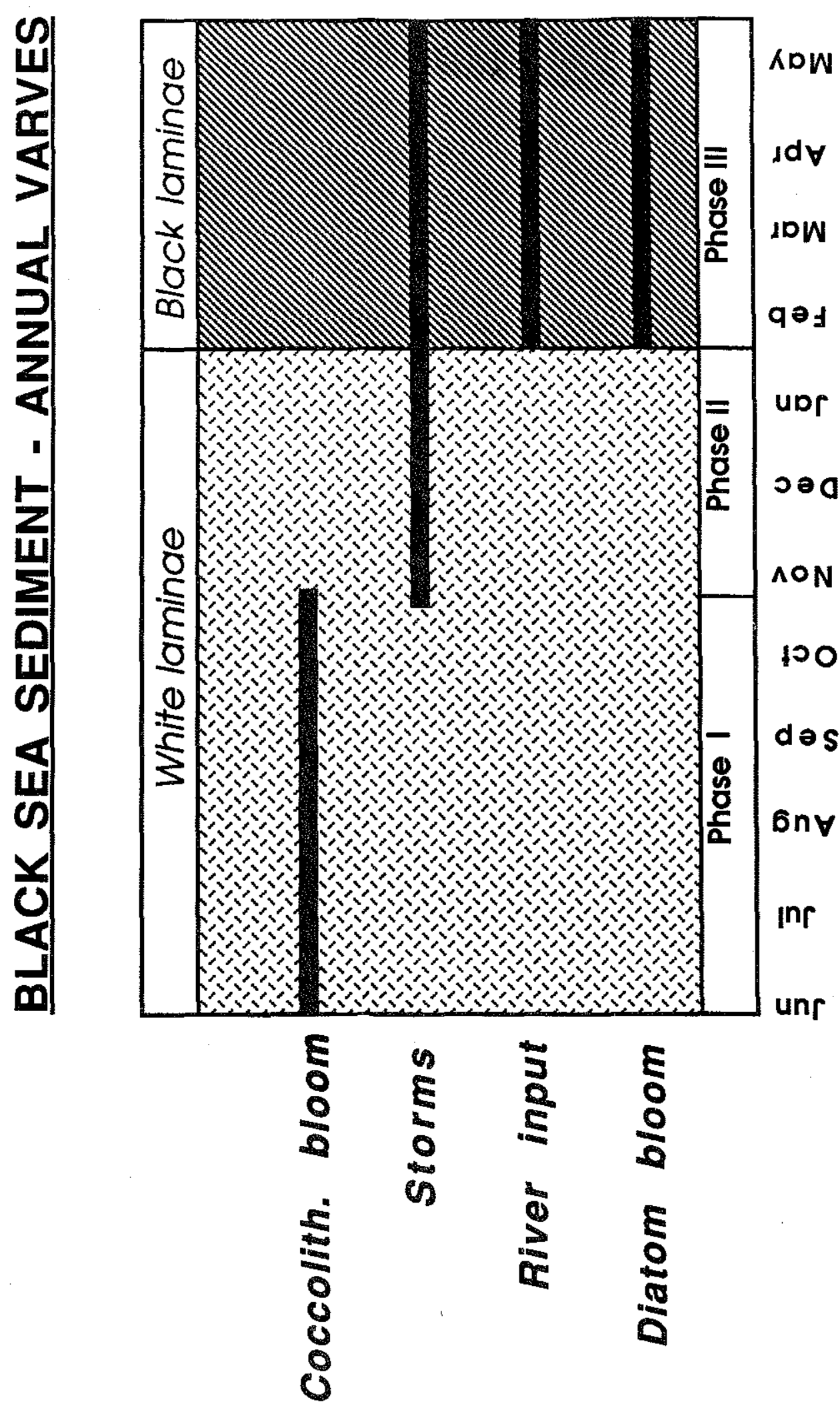


rivers. Phase III is also the time period of the maximum diatom production near the trap site BS as well as in the northwestern Black Sea (Morozova-Vodyanitskaja, 1948). However, because of substantial dissolution of silica at depth, diatoms are relatively insignificant contributors to the sediment record. On the other hand, they may play an important role in the generation of the black laminae (Caraco and Honjo, 1987).

\subsection{CONCLUSIONS}

The present-day particle flux in the southwestern Black Sea is about 5.5 times smaller than the paleoflux over the last 1,000 years (unit I) in the central part of the western Black Sea. The present-day carbonate flux is smaller by a factor of 11 , the lithogenic flux by a factor of 3. The difference is caused by the differences in the particle source area. Site BS receives particles predominantly from the Turkish coast while the central part of the western Black Sea receives particles most1y from the northwest, where supply of biogenic and 1ithogenic particles is considerably higher. Shelf-settled particles are further resuspended and transported offshelf by storms, which may account for the pronounced compositional contrast between the black and white laminae in unit I. Carbonate content in these white laminae averages 94 $\%$. 
Throughout the anoxic history of the Black Sea over the last 5,000 years the major change in paleoflux occurred at about 1,000 years B.P. with the introduction of Emiliania huxleyi. The three-fold increase in the paleoflux from unit II to unit I and the variability in the total paleoflux within unit $I$ of the western Black Sea was essentially a function of variations in the supply of Emiliania huxleyi. Within unit II the variability in total paleoflux was a function of the variations in river input of terrigenous particles. Over the last 5,000 years the supply of terrigenous particles did not appear to change significantly.

The timing of the particle supply processes is reflected in the composition of the sediment trap material and possibly of the laminated bottom sediments. Based on data from station BS, the sediment deposited during Phase I (coccolithophorid bloom; June-0ctober) and Phase II (shelf resuspension; November-January) corresponds with the deposition of the white laminae in unit I. The sediment deposition during Phase III (river input, bloom of dominantly silicious organisms; February-May) corresponds with the deposition of the black laminae in that unit. 
$-130-$ 
$-131-$

Chapter 3

SEASONAL VARIABILITY IN THE TITANIUM TO ALUMINUM RATIO

IN THE PARTICULATE MATTER OF THE BLACK SEA:

POSSIBLE TRACER FOR DANUBE INPUT 
Annual variability in the flux of $\mathrm{Ti}, \mathrm{A} 1, \mathrm{Ni}, \mathrm{Cu}$, organic carbon, and lithogenic matter was studied using particulate matter from two sites in the southwestern Black Sea (sites BS and BSC). Simultaneously, illite/montmorillonite ratios were determined from a one-year record from site BS. Data were integrated with relevant measurements from Black Sea shelf and basin floor sediments as well as suspended particulates from rivers.

In the southwestern Black Sea, terrigenous matter is largely supplied by the adjacent Western Anatolian rivers. Between May and September, suspended matter from the Danube appears to contribute to the lithogenic flux as indicated by a higher $\mathrm{Ti} / \mathrm{Al}$ ratio. The time-series $\mathrm{Ti} / \mathrm{A} 1$ ratio varies seasonally. At site $\mathrm{BS}$, it averages 0.048 (st.dev.: 0.002 ) from October to March and 0.061 (st.dev.: 0.003 ) from May to September, higher by about $30 \%$. The Ti/A1 ratio in the 0ctober-March period reflects the ratio measured in the suspended matter from the Western Anatolian rivers, while the ratio in the summer resembles the higher ratio of the Danube shelf particulates. Comparison of the Ti/A1 ratio with the time-series illite/montmorillonite ratios in the trap samples suggests that the variability in the Ti/A1 ratio may be a useful tracer for terrigenous matter (i) from the Danube in the Black Sea in particular, and (ii) possibly in marine environments in general. 


\subsection{INTRODUCTION}

Presently the Black Sea is a giant catch basin for the river discharge of half of Europe and part of Asia Minor. About $60 \%$ of the particulate and dissolved load to the Black Sea comes from the Danube drainage system, $20 \%$ from the Caucasian rivers Rioni and Coruh, and the remaining $20 \%$ from the Dnestr, Bug, Dnepr, and the Bulgarian and Anatolian rivers (Shimkus and Trimonis, 1974; Table 8). The river discharge of the Danube is highest in spring with discharge reaching a maximum in May (UNESCO, 1978). The discharge pattern of the Western Anatolian rivers is similar but with a discharge maximum in March. Minor amounts of detritus are supplied from shelf and shore erosion, particularly from the Danube fan, which contributes about $10 \%$ to the total detrital input to the Black Sea (Aybulatov and Novikova, 1984).

The Danube therefore has a profound impact on the supply of terrigenous particles to the basin floor and indirectly to biogenic particle production as we11, via the supply of nutrients. Glenn and Arthur (1985) calculated that only $75 \%$ of the nutrients can be accounted for by upwelling of deeper water; the remaining $25 \%$ were attributed to river input. The Danube river input is expected to influence the biocoenosis as well as the temporal and geographic variability in the particle $f l u x$, especially in the western Black Sea. 
Table 8: Input of detrital and dissolved load by the major rivers surrounding the Black Sea, as well as characteristic Ti/Al and illite/montmorillonite ratios.

\begin{tabular}{|c|c|c|c|c|c|c|}
\hline & $\begin{array}{l}\text { Liquid } \\
\text { discharge } \\
\left(\mathrm{km}^{3}\right) \\
(1)\end{array}$ & $\begin{array}{l}\text { Detritus } \\
\left(10^{6} t / y r\right) \\
(1)\end{array}$ & $\begin{array}{l}\text { Salts } \\
\left(10^{6} t / y r\right) \\
(1)\end{array}$ & $\begin{array}{l}\text { Drainage } \\
\text { area } \\
\left(\mathrm{km}^{2}\right) \\
(2)\end{array}$ & $\begin{array}{l}\text { Illite/ } \\
\text { Montm. } \\
\text { ratio } \\
\text { (3) }\end{array}$ & $\begin{array}{l}\mathrm{Ti} / \mathrm{Al} \\
\text { ratio } \\
\text { (4) }\end{array}$ \\
\hline $\begin{array}{l}\text { Danube } \\
\text { Dnestr } \\
\text { Y.Bug } \\
\text { Dnepr } \\
\text { Don } \\
\text { Kuban } \\
\text { Caucasian rivers } \\
\text { Rioni } \\
\text { Coruh } \\
\text { Bulgarian coast } \\
\text { Turkish coast } \\
\text { Sakarya Nehri } \\
\text { Filyos } \\
\text { Kocacay } \\
\text { Kizil Irmak } \\
\text { Yesil Irmak } \\
\text { Melet } \\
\text { Aksu } \\
\text { Harsit } \\
\text { Haldizen }\end{array}$ & $\begin{array}{r}198 \\
10 \\
3 \\
52 \\
28 \\
13 \\
\\
41 \\
\\
3 \\
25\end{array}$ & $\begin{array}{r}83.00 \\
2.50 \\
0.53 \\
2.12 \\
6.40 \\
8.40 \\
6.79 \\
7.08 \\
15.13 \\
0.50 \\
17.00\end{array}$ & $\begin{array}{r}52.51 \\
2.79 \\
1.35 \\
10.79 \\
8.43 \\
1.95 \\
\\
2.16 \\
0.80 \\
6.70\end{array}$ & $\begin{array}{r}681,000 \\
61,900 \\
34,000 \\
383,500 \\
446,500 \\
63,500 \\
24,100 \\
15,800 \\
16,700 \\
22,200 \\
231,500 \\
55,322 \\
1,342\end{array}$ & $\begin{array}{l}0.53 \\
1.07 \\
7.00 \\
0.89 \\
0.26 \\
0.51 \\
0.48 \\
0.42 \\
0.32\end{array}$ & $\begin{array}{l}0.053 \\
0.049\end{array}$ \\
\hline$\overline{\text { Total }}$ & 374 & 149.45 & & & & \\
\hline
\end{tabular}

\footnotetext{
(1) Shimkus and Trimonis (1974)

(2) Degens et al. (1978)

(3) computed from Miiller and Stoffers (1974)

(4) Anatolian rivers: this chapter

Danube:

Georgescu et al. (1973)
} 
The counterclockwise circulation of the Black Sea has caused the Danube fan to extend more towards the southwest (Neumann, 1942). The sediment supply at the slope along the Bulgarian coast has been twice as high as in the western Black Sea over the last 5,000 years (Degens et al., 1980; chapter 2). While the coarser fraction of the river input settles on the shelf, the finer fraction remains in suspension longer, possibly being transported to the southwestern. Black Sea, where it contributes to the particle flux in that area.

A currently ongoing sediment trap experiment has allowed the investigation of the relative importance of Danube particulates to the overall sedimentation in the southwestern Black Sea. In this study, sediment trap samples were used to measure $\mathrm{Ti}, \mathrm{Al}, \mathrm{Cu}, \mathrm{Ni}$, and, the clay minerals illite and montmorillonite. Data were compared with data from relevant rivers and bottom sediments from the Black Sea she1f and slope. The focus of this chapter was to investigate the usefulness of the Ti/A1 ratio in comparison to the illite/montmorillonite ratio as tracers for seasonally varying input of terrigenous matter from the Danube. 


\subsection{METHODS}

\subsubsection{Samples}

At site BS two time-series sediment traps were moored in vertical array at $250 \mathrm{~m}$ and $1,200 \mathrm{~m}$ in the southwestern Black Sea from October 28, 1982 to April 6, 1987 (chapter 1; Fig. 1). The project was continued in the aftermath of the Chernobyl accident at a site (site BSC) further to the west of the initial sediment trap site (site BS), beginning on June 19, 1986 (Buesseler et al., 1987; Kempe et a1., 1987). The average sampling interval of the traps was 2 weeks at site BS and 7.5 days at site BSC. Further technical details about the mooring itself and the preparation and treatment of the samples is given in chapter 1 .

Samples of suspended river particles were collected from the Western Anatolian rivers Filyos and Kocacay in April, 1983, and September, 1985, respectively (Fig. 1). Landsat imagery has shown the significance of these rivers for the terrigenous input at the sediment trap site BS (Fig. 7). Shelf sediments (core tops) were collected along a transect from Amasra to the trap site BS by gravity coring with the R/V KOCA PIRI REIS. Six samples from the outer shelf and slope of the Danube fan were analyzed from the top $20 \mathrm{~cm}$ of cores 1442, 1443, 1444, $1445,1450,1451$, and 1461, collected by gravity coring by the $R / V$ ATLANTIS, cruise \#49. One sample of a turbidite bed was analyzed from 
gravity core 18, collected during the R/V CHAIN cruise 120-1 in 1975 (Degens et al., 1980). The turbidite was deposited at around 500 years B.P. as determined from varve counting (Degens et al., 1980).

\subsubsection{Analysis}

Chemical analyses for the sediment trap samples, river and shelf samples for the components carbonate, organic carbon, biogenic silica, and lithogenic matter were carried out after the method described in chapter 1. Elemental analysis was carried out by inductively coupled plasma atomic emission spectrometry (ICPES) as described in Floyd et al. (1980). The wavelengths used for element identification were $337.265 \mathrm{~nm}$ (Ti), $396.138 \mathrm{~nm}(\mathrm{Al}), 327.369 \mathrm{~nm}(\mathrm{Cu})$, and $232.002 \mathrm{~nm}$ (Ni). As standards, synthetic aqueous solutions in a matrix of $0.56 \%$ weight/volume $\mathrm{LiBO}_{2}$ in $4 \%$ nitric acid were used. The analytical precision as expressed in percent relative standard deviation for $\mathrm{Ti}$, $\mathrm{Al}, \mathrm{Cu}$, and $\mathrm{Ni}$ using ICPES was $2 \%$. At site BS, samples from the 1,200 m trap were analyzed from May 3, 1984, to April 6, 1984. From the $250 \mathrm{~m}$ trap, every second sediment trap sample from 0ctober 8, 1984, to March 7, 1985 was analyzed (Oct 8, Nov 7, Dec 7, Jan 6, Feb 5, Mar 7). At site $B S C$, nine samples from the $1,200 \mathrm{~m}$ trap were analyzed from June 19 , 1986, to August 25, 1986. From the $250 \mathrm{~m}$ trap at site BSC, two samples were analyzed from July 11 and July 18, 1986. The elemental and the bulk chemical flux data were normalized to the $A 1$ flux, since Al is a 
chemically unreactive component of clay minerals and best reflects riverine input.

For the clay mineral analysis a representative split of the $<2$ um fraction from each sediment trap sample was filtered onto a silver membrane filter and dried at $20^{\circ} \mathrm{C}$. The filter was then mounted in an automatic sample holder and X-rayed using an I.C. X-ray diffraction unit between the angles $(2 \Theta) 2^{\circ}$ and $40^{\circ}$ using $\mathrm{CuK \alpha}$ radiation and a scanning rate of $2 \%$ minute. Each sample was X-rayed after each of the following three steps: (1) drying on filter at room temperature, (2) vapor-induced glycolation with ethylene glycol for 4 hours, and (3) heating to $400{ }^{\circ} \mathrm{C}$ for $1 / 2$ hour. Quartz standards were run daily to accommodate short-term fluctuations in power or equipment alignment. The semi-quantitative determination of the clay mineral groups was done from the clay mineral peak areas using the classification scheme of Biscaye (1965) and Poppe and Hathaway (1986). Clay mineralogical data from Miiller and Stoffers (1974) for the Danube and Turkish rivers as wel1 as from surface sediments of the basin floor were used for the calculation of the illite/montmorillonite ratios for comparison with the sediment trap data. 


\subsection{RESULTS}

\subsubsection{Ti/A1 Ratio}

In the Black sea the flux of $\mathrm{Ti}$ is closely linked to the $\mathrm{A} 1 \mathrm{flux}$ ( $\mathrm{r}$ $=0.99, \mathrm{p}<0.001, \mathrm{n}=31)$, confirming the overwhelmingly terrigenous sources of Ti (Figs. $28 \& 29$ ). Nevertheless, the time-series Ti/A1 ratio varies seasonally (Fig. 30 ). In the $1,200 \mathrm{~m}$ trap the $\mathrm{Ti} / \mathrm{Al}$ ratio averages 0.048 (st.dev.: 0.002) from October to March and 0.061 (st.dev.: 0.003) from May to September at site BS, higher by about $30 \%$ (Table 9). In the summer of 1986 at site $\mathrm{BSC}$, the $\mathrm{Ti} / \mathrm{Al}$ ratio in the $1,200 \mathrm{~m}$ trap was also higher with an average value of 0.056 (st.dev.: 0.004 ) in the $1,200 \mathrm{~m}$ trap. Data from the samples in the $250 \mathrm{~m}$ traps from both sites are comparable to the 1,200 $\mathrm{m}$ traps (Fig. 30; Tab1e 9). A t-test of the difference between the mean May-September value of 0.061 and the mean 0ctober-March value of 0.048 (using integral sample sizes) showed that these means were significantly different from each other at the $p<0.001$ leve1 of significance.

$\mathrm{Ti} / \mathrm{Al}$ ratios in the sediment trap samples in the October-March period resembles the $\mathrm{Ti} / \mathrm{A} 1$ ratios of the sediments from the Western Anatolian rivers and the adjacent shelf and slope (Table 9). Ti/Al ratios of the sediments near the mouth of the Danube and from the turbidite derived from the Danube fan more closely resemble the Ti/Al ratios in the sediment traps for the May-September period. Ti/A1 ratios 
Figure 28: Time-series data of the $\mathrm{Ti}$ and $\mathrm{Al}$ flux at trap sites $\mathrm{BS}$ and BSC .

Figure 29: Correlation between the Ti and Al flux in the samples of the $1,200 \mathrm{~m}$ sediment traps of sites BS and BSC. Data were plotted with different symbols for the two time periods May-September and October-March. 

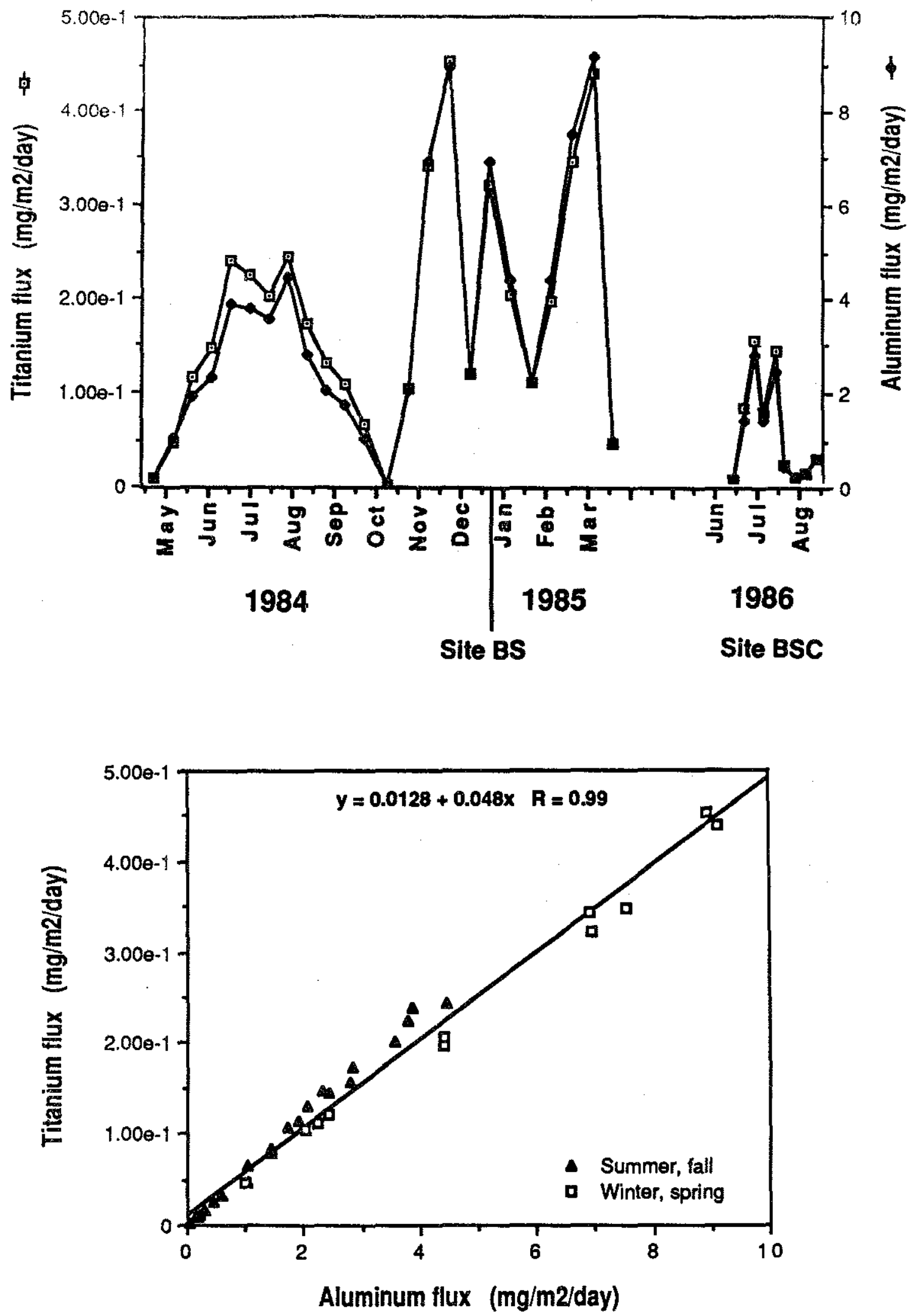
Table 9: Summary of $\mathrm{Ti} / \mathrm{Al}$ ratios from various samples of the sediment traps, shelf sediments, and river sediments used in the study.

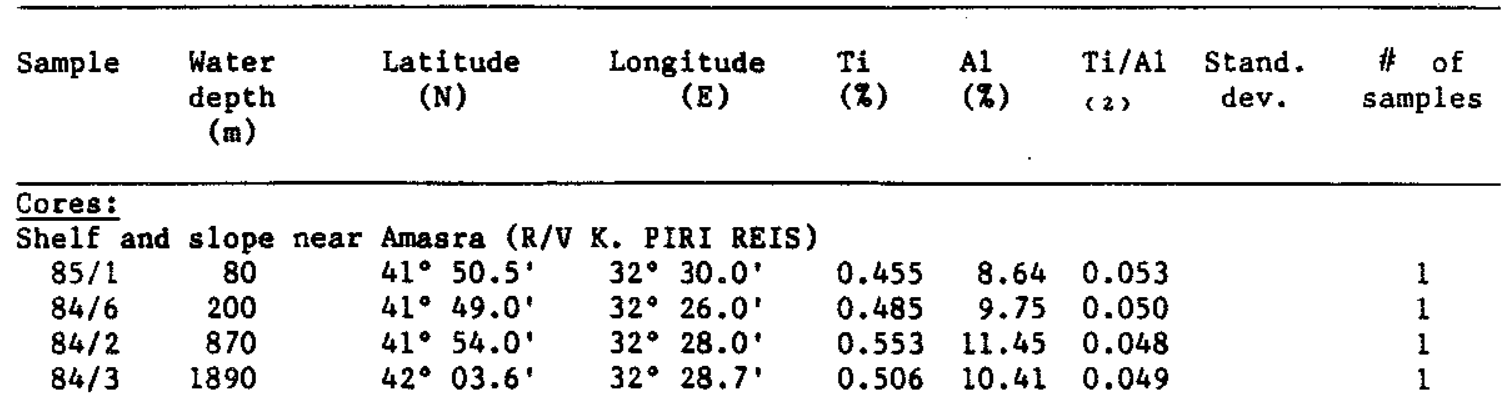

Shelf near the Danube river mouth (1)

$\begin{array}{llll}0.411 & 7.45 & 0.057 & 6\end{array}$

Slope of the Danube fan (R/V ATLANTIS II)

$\begin{array}{lllll}0.225 & 5.21 & 0.043 & 0.002 & 7\end{array}$

Turbidite, western Black Sea ( $R / \mathrm{V}$ CHAIN)
$18 / 12 \quad 2160$
$42^{\circ} 59^{\circ}$
$33^{\circ} 59^{\prime}$
0.491
7.850 .063
1

$\frac{\text { Suspended sediment, W-Anatolian rivers: }}{\text { Filyos }}$

$\begin{array}{lll}0.398 & 7.52 & 0.053\end{array}$

$\begin{array}{lll}0.504 & 10.23 & 0.049\end{array}$

1

Kocacay

0.50410 .23

\section{Sediment traps: \\ $250 \mathrm{~m}$ trap \\ BS \\ BSC \\ 1,200n trap \\ BS \\ BS \\ BSC}

(Oct/08/84-Mar/07/85)

(Jul/11/86-Jul/26/86)

$\begin{array}{lll}0.049 & 0.003 & 6 \\ 0.058 & & 2\end{array}$

(May/17/84-Sep/20/84)

(Oct/23/84-Mar/22/85)

(Jun/19/86-Aug/25/86)

0.061

0.048

0.056

0.003

0.002

(May-September, 1984+1986)

$0.059 \quad 0.004$

19

Data are obtained from Georgescu et al. (1973). Samples were collected from the shelf sediments at the mouth of the Danube river. means.
} 
Figure 30: Time-series data of the ratios Ti/A1, Lithogenics/Al, Carbonate/A1, Sibiogenic/Al, Corg/Al, Cu/A1, and Ni/A1 for the $250 \mathrm{~m}$ and $1,200 \mathrm{~m}$ sediment trap samples from sites BS and BSC in $1984 / 85$ and 1986. The carbonate flux in the southwestern Black Sea consists dominantly of biogenic carbonate produced by Emiliania huxleyi (Trimonis, 1974; chapter 1). The Sibiogenlc flux in the southwestern Black Sea consists dominantly of diatoms and, to a lesser extent, silicoflagellates (Ben1i, 1987; chapter 1). 

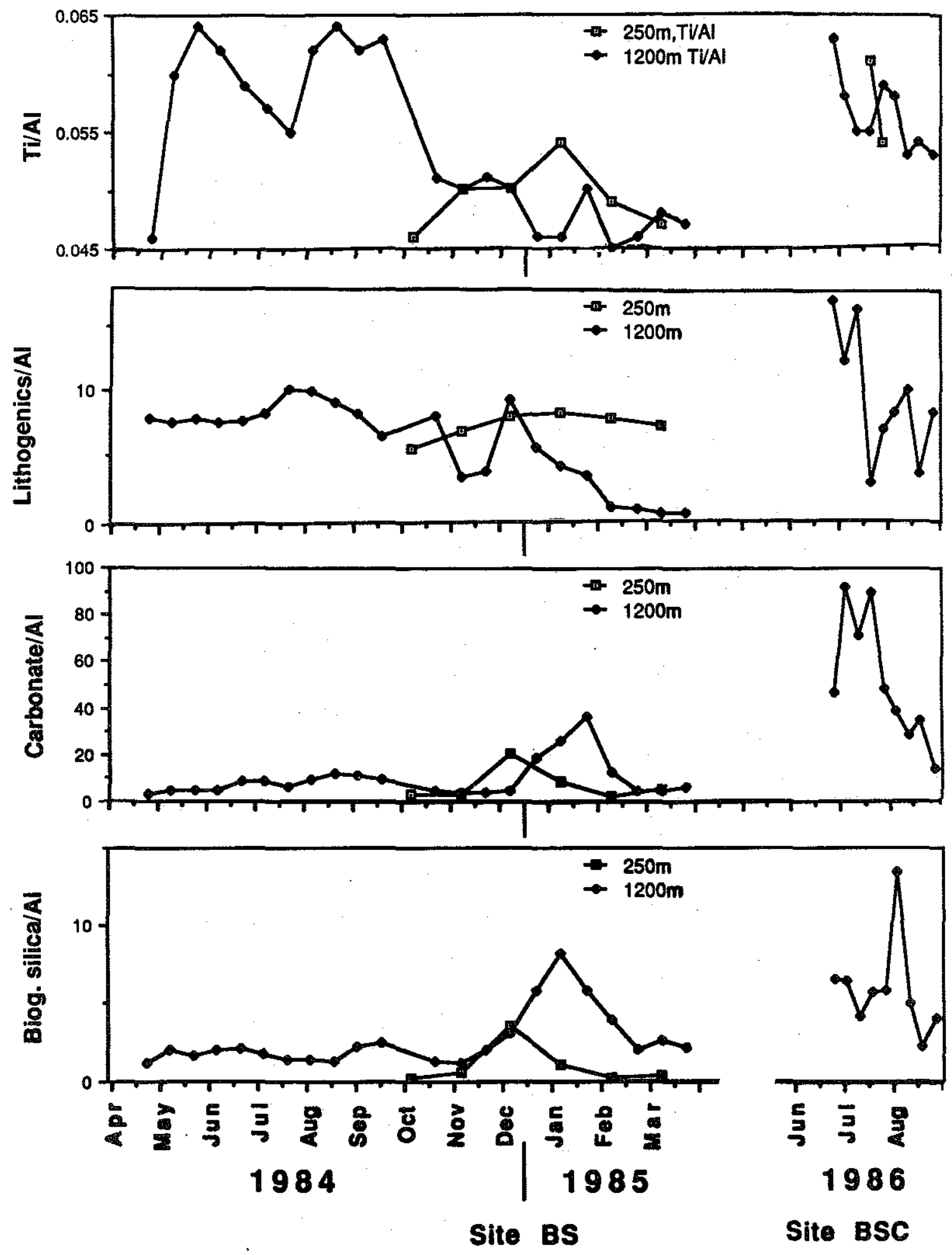

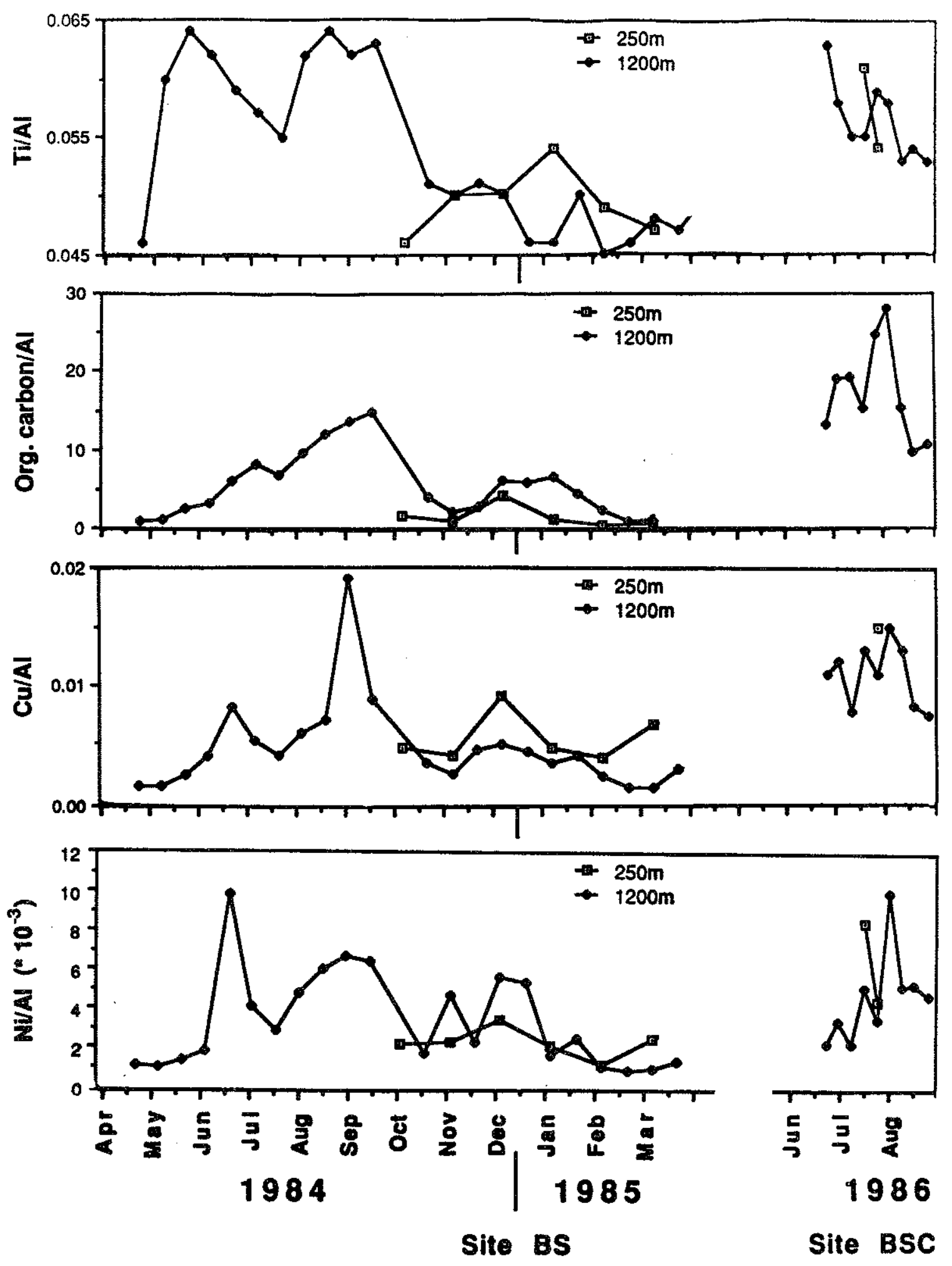
Figure 31: Particle flux in the 1,200 traps at the sediment trap sites BS (chapter 1) and BSC for the time periods from May 1984 to Apri1 1985 (site BS) and from June to September 1986 (site BSC). 


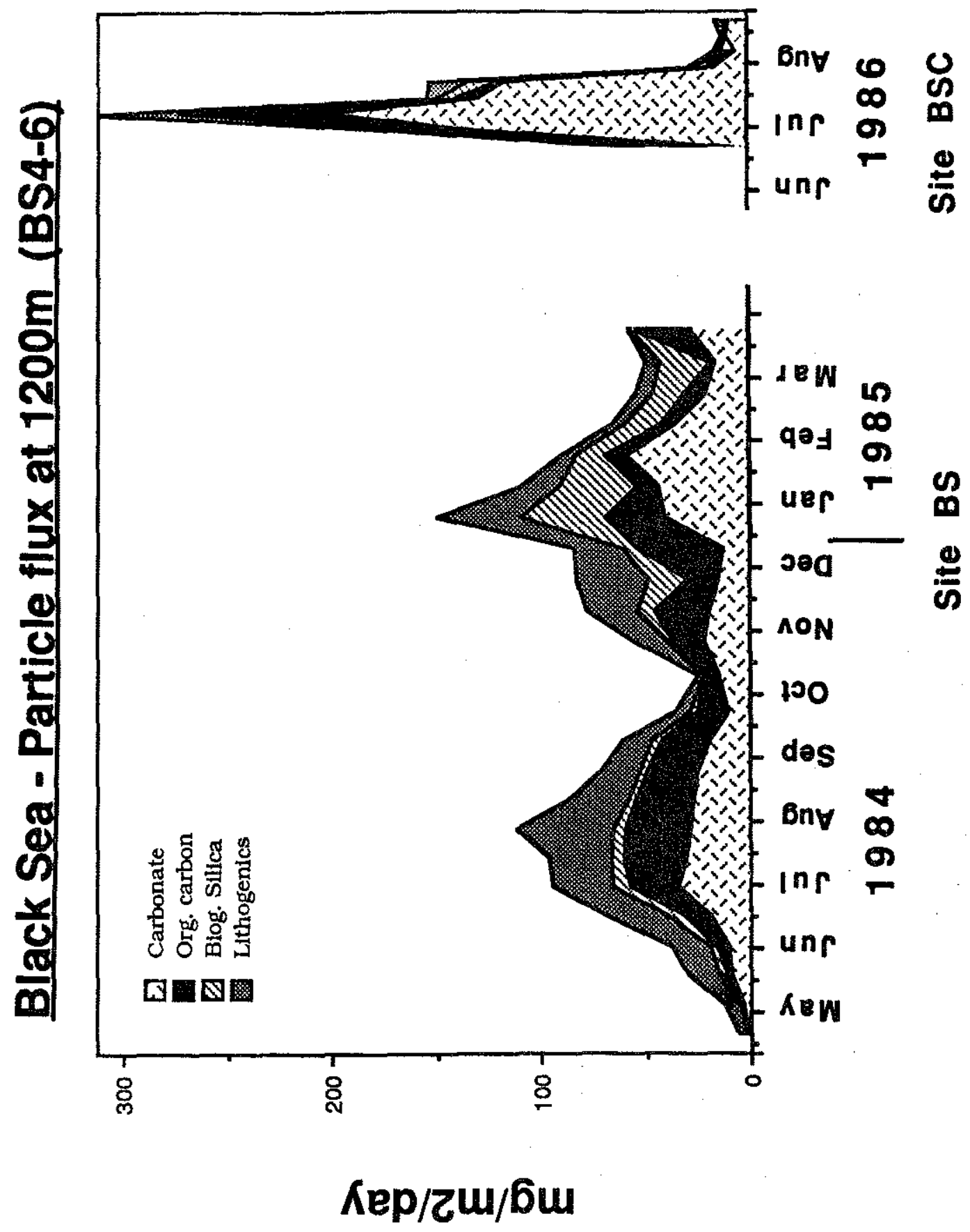


Figure 32: Correlations between the Ti/A1 ratios and the Corg./Al, lithogenics/A1, $\mathrm{Si}_{\mathrm{biogenic}} / \mathrm{Al}$, and the carbonate/Al ratios as well as correlations between the Corg./A1 ratio and the $\mathrm{Cu} / \mathrm{A} 1$ and $\mathrm{Ni} / \mathrm{Al}$ ratios for the $1,200 \mathrm{~m}$ trap samples. 

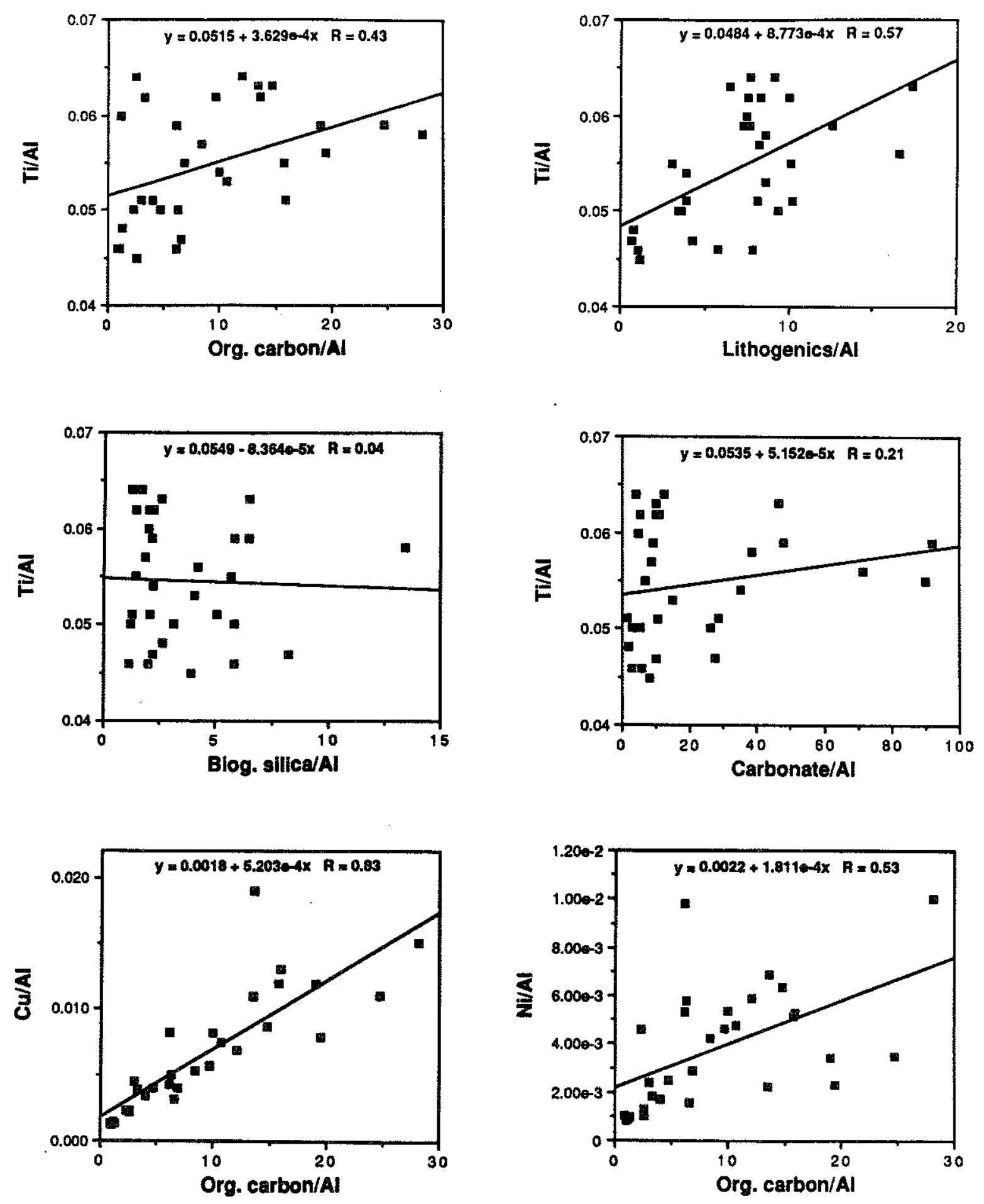
from the slope of the Danube fan ( $R / V$ ATLANTIS II cores) were lower, however, with an average of 0.044 .

The seasonal variability of the $\mathrm{Ti} / \mathrm{A} 1$ ratio is not related to the variability in the lithogenic flux (Fig. 31). The correlation between the $\mathrm{Ti} / \mathrm{Al}$ ratio and the lithogenic flux is 0.01 from samples of the $1,200 \mathrm{~m}$ traps, suggesting that the ratio is independent of the absolute lithogenic flux. On average, the lithogenic flux in the $1,200 \mathrm{~m}$ traps is high during all times of the year (Figs. 28 \& 31 ). The relative A1 content in the lithogenic flux, however, varies seasonally, indicating different sources of terrigenous matter during different time periods in the year. The lithogenics/A1 ratio is significantly correlated with the $\mathrm{Ti} / \mathrm{Al}$ ratio $(\mathrm{r}=0.57, \mathrm{p}<0.001, \mathrm{n}=31,1,200 \mathrm{~m}$ traps $)(\mathrm{Fig}, 32)$, suggesting that also the variability in the $\mathrm{Ti} / \mathrm{Al}$ ratio is caused by different terrigenous sources.

The organic carbon flux is largest during the summer with smaller values from fall to spring (Fig. 31). The largest organic carbon flux coincides with the time of the coccolithophorid bloom (chapter 1). As expressed by the Corg/A1 ratio, the organic carbon flux is highest relative to the terrigenous matter flux between July and September (Fig. 30). 


\subsubsection{Illite/montmorillonite ratio}

The suspended matter of the Danube has a distinctly different illite/montmorillonite ratio compared to the Western Anatolian rivers (Fig. 33), as calculated from data presented by Müller and Stoffers (1974). While the Danube has a ratio of 5.29 , the Western Anatolian rivers Sakarya Nehri and Filyos have a ratio of 0.53 and 1.07 , respectively. The smaller river Kocacay has a relatively high ratio of 7.0; however, based on its river discharge it is relatively insignificant in its suspended sediment input to the Black Sea (Table 8).

The distribution of the illite/montmorillonite ratio in the Black Sea basin floor sediments reflects the dispersal pattern of terrigenous particles (Fig. 33). The western Black Sea is dominated by terrigenous input of the Danube while the southern Black Sea along the Anatolian coast receives dominantly sediment from the adjacent Turkish rivers. Illite/montmorillonite ratios in the northeastern Black Sea probably reflect the input from the Caucasus mountains, although no clay mineralogical data are readily available at present from the respective Russian rivers.

I11ite/montmorillonite ratios in the $1,200 \mathrm{~m}$ trap in the summer and early fall (Phase I, June-September) are comparatively stable, centering around 1.9 (Fig. 34). In late fall and winter (Phase II, October-January), the illite/montmorillonite ratio displays a high 
Figure 33: Distribution of illite/montmorillonite ratio in the surface sediments of the Black Sea, the Danube and the Western Anatolian rivers. The ratios are calculated from samples collected during the $R / V$ ATLANTIS cruise $\$ 49$ in 1969 from data presented by Müller and Stoffers (1974). The sediment trap sites BS and BSC are marked. 


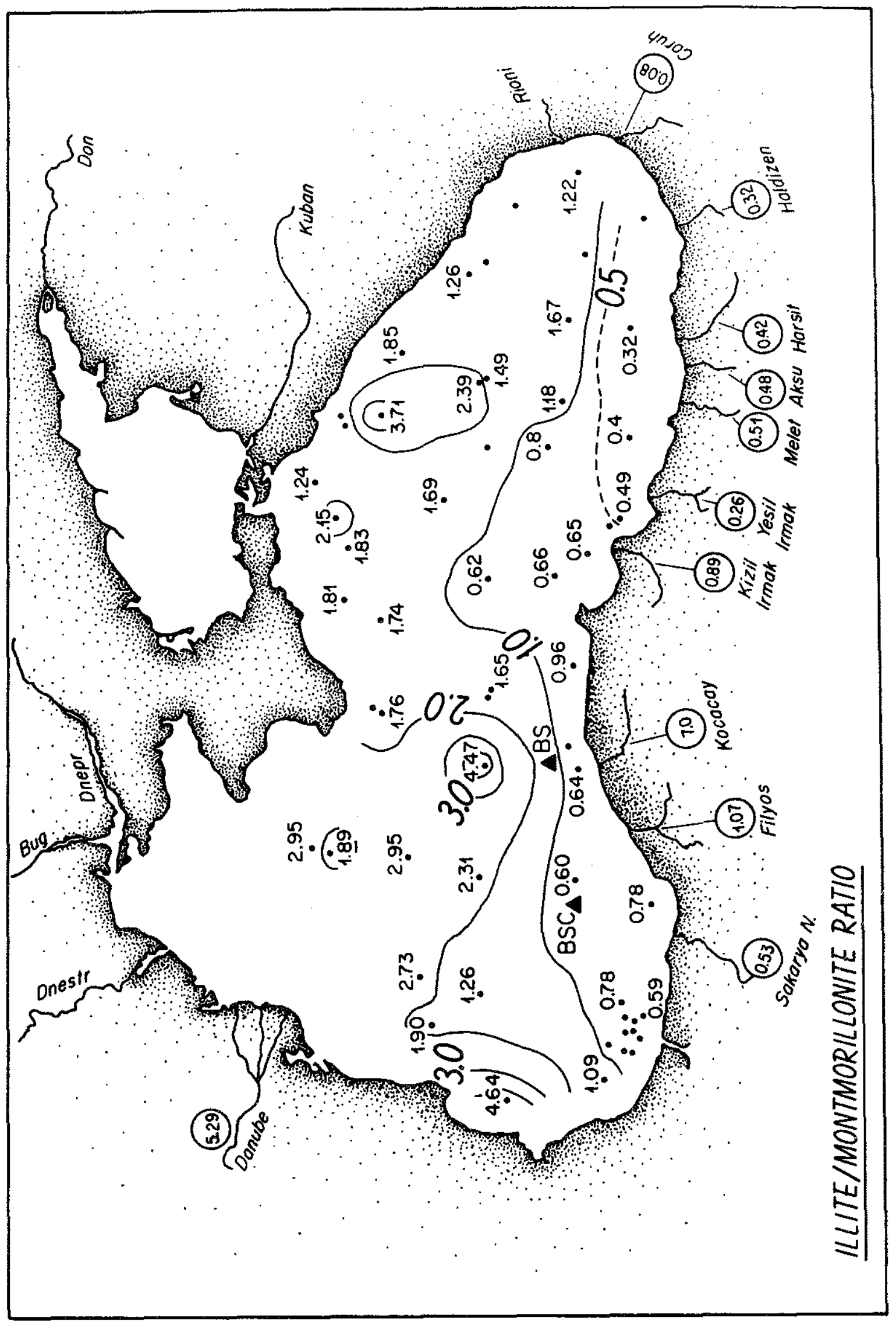


Figure 34: I1lite/montmorillonite ratios in the 1,200 $\mathrm{m}$ sediment trap samples from site BS from samples collected between June 9, 1983, and April 15, 1984, by the R/V K. PIRI REIS. 


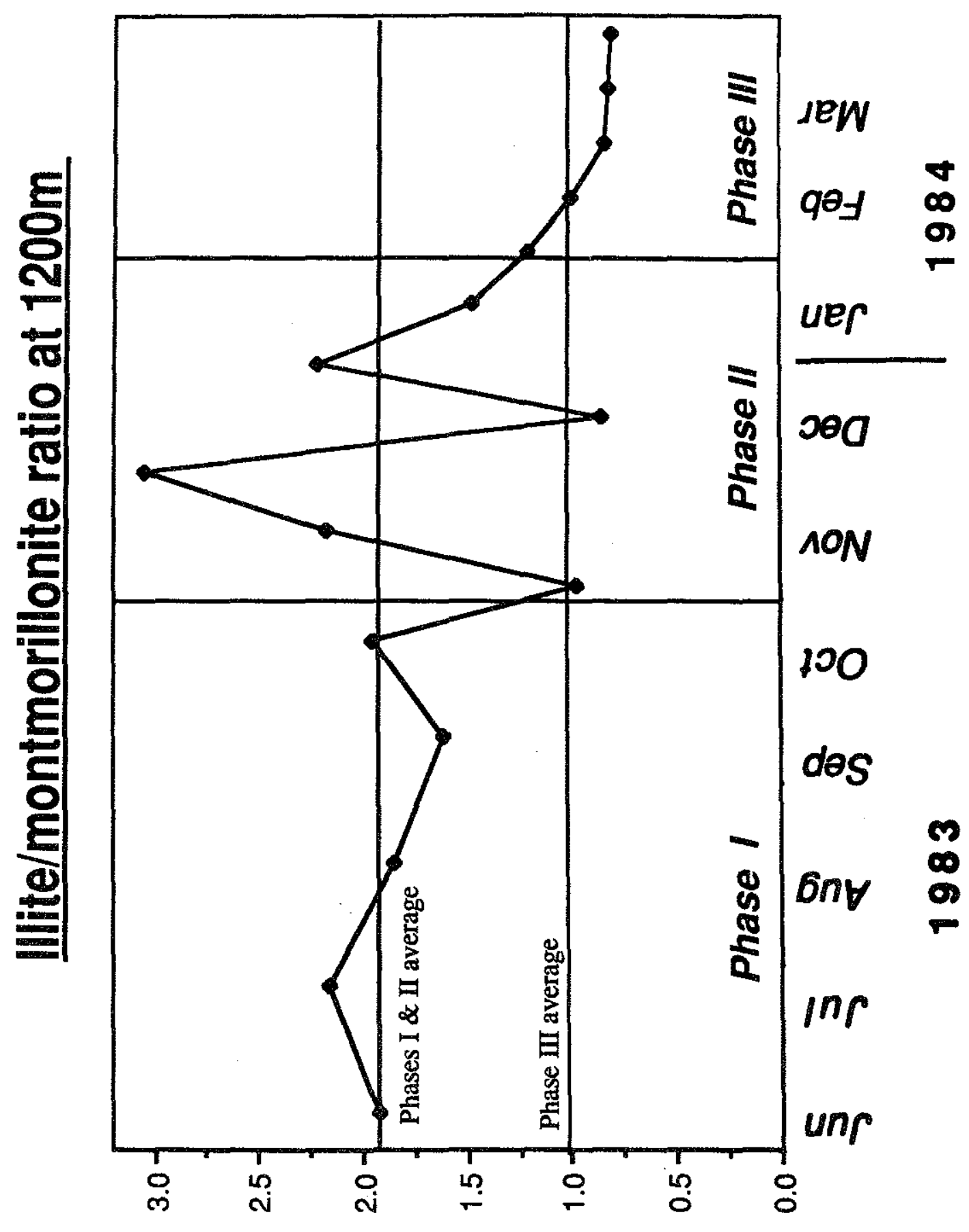


between-sample variability with a mean value similar to that in the preceding summer months. In late winter to spring (Phase III, February-Apri1) the ratio drops by about a factor of 2 , averaging about 0.9 .

\subsection{SEASONAL VARIABILITY OF THE Ti/A1 RATIO - DISCUSSION}

Possible explanations for the higher $\mathrm{Ti} / \mathrm{Al}$ ratio in the sediment trap samples could be (1) seasonal variability in the supply of terrigenous matter from different sources, (2) seasonal variability in the composition and grain size of the lithogenic matter from one source, and (3) biological uptake of $\mathrm{Ti}$ during the May-September period, either directly by the organisms or by adsorption onto settling biogenic matter. Each possibility is briefly discussed and evaluated as an explanation for the observed seasonal variability of the Ti/Al ratio in the particle flux of the southwestern Black Sea.

\subsubsection{Seasonal variability in the terrigenous sources}

Titanium is a minor constituent in most aluminosilicates (Table 10). Migdisov (1960) studied $\mathrm{Ti}$ in a large number of sediments from the Russian platform and concluded that the geochemical cycles of $\mathrm{Ti}$ and A1 are very similar. Both elements have a relatively low solubility and 
Table 10: Characteristic $\mathrm{Ti} / \mathrm{Al}, \mathrm{Cu} / \mathrm{Al}$, and $\mathrm{Ni} / \mathrm{Al}$ ratios in various types of rocks.

$\begin{array}{llll}\text { GENERAL } & \mathrm{Ti} / \mathrm{A} 1 & \mathrm{Cu} / \mathrm{A} 1 & \mathrm{Ni} / \mathrm{Al}\end{array}$

(1) after Turekian and Wedepoh1, 1961

Basaltic

Granitic (low calcium) (high calcium)

Sedimentary rocks shales sands tones carbonates

Deep sea sediments carbonate clay
0.18

0.017

0.040

0.058

0.06

0.095

0.039

0.055
0.0011

0.00013

0.00037

0.00056

$-$

0.00095

0.0015

0.0030
0.0017

0.000063

0.00018

0.00085

0.000080

0.0048

0.0015

0.0027

(2) after Taylor, 1964

Crustal average

Basaltic average

Granitic average
0.0693

0.103

0.0299
0.000668

0.00114

0.00013
0.000911

0.00171

0.0000065 
hence are concentrated as residual products of chemical weathering. The Ti/A1 ratio in weathering products of rocks is very dependent on source area. Highest $\mathrm{Ti} / \mathrm{A} 1$ ratios exist in mafic rocks; the $\mathrm{Ti} / \mathrm{A} 1$ ratios in felsic rocks is low (Table 10 ). The high $\mathrm{Ti} / \mathrm{Al}$ ratios found in mafic igneous rocks is probably reflected in the residual clays (Migdisov, 1960).

Ti in marine sediments is mostly derived from weathered continental minerals (Chester and Aston, 1976). The close association of Ti with terrigenous matter was shown by Brewer et al. (1980), who studied elemental fluxes throughout the North Atlantic water column (E site, 380 miles east of Barbados on the Demerara Abyssal Plain). With depth, the Ti/A1 ratio remained quite constant with ratios of $0.052,0.053,0.052$ and 0.057 at $389 \mathrm{~m}, 988 \mathrm{~m}, 3,755 \mathrm{~m}$ and $5,086 \mathrm{~m}$, respectively (Brewer et a1., 1980).

Seasonal variability in the supply of terrigenous particles from different sources is a possible explanation for the seasonal variability in the $T i / A 1$ ratio in sediment trap samples. The Ti/A1 ratio reflected in the Western Anatolian river, shelf, and slope sediments resemble the ratio found for the October-March period in the sediment trap. Discharge of the Western Anatolian rivers is highest between December and April (Fig. 6a), transporting high loads of suspended matter as seen also in the Landsat image from April 27, 1984 (Fig. 7). The Ti/A1 ratio in October and November, when river discharge of the Western Anatolian 
rivers is relatively low, could be explained by resuspension and offshelf-transport of terrigenous sediment by storms with the beginning of the storm season in the fall (chapter 1).

The higher Ti/Al ratio in the May-September period could be the result of an increase in the contribution of terrigenous matter from the Danube to the particle flux at the trap sites. The Ti/A1 ratio in the sediments at the mouth of the Danube is 0.057 (Georgescu et al., 1973). In addition, if the chemical compositions of the phytoplankton samples from the NW Black Sea measured by Vinogradova and Kovalskiy (1962) are indeed biased by contamination with aluminosilicates (see section 3.4.3.), then the $\mathrm{Ti} / \mathrm{Al}$ ratio of these samples reflects the $\mathrm{Ti} / \mathrm{A} 1$ ratio of the suspended aluminosilicates from that area. The Ti/A1 ratio measured by Vinogradova and Kovalskiy (1962) in the diatom samples centered around 0.08 (Table 11).

The extent of fine-grained sediment dispersal by outflow of particulate matter from the Danube is shown by the distribution of the higher illite/montmorillonite ratios in the western Black Sea surface sediments (Fig. 33). Sediments with a ratio more characteristic of the Danube particulates cover most of the western Black Sea. The Danube discharge is highest between March and July (Fig. 6b). At a current speed of $5-20 \mathrm{~km} /$ day (Neumann, 1942) and a counterclockwise circulation system (Neumann, 1942) the suspended matter from the Danube would arrive at the trap sites one to two months after it entered the Black Sea, i.e. 
Table 11: $\mathrm{Ti}$ and $\mathrm{Al}$ concentration in planktonic organisms in the Black Sea (from Vinogradova and Koval'skiy, 1962). High A1 content indicates the ossibility of contamination of the plankton samples by, ay minerals. Data were determined by spectrographic analysis (Floyd et al, 1980).

Organism $\quad \begin{aligned} & \mathrm{Ti} \\ & \text { (\% in ash })\end{aligned} \quad \begin{aligned} & \mathrm{A} 1 \\ & \text { in ash })\end{aligned} \quad \mathrm{Ti} / \mathrm{A} 1$ ratio

\begin{tabular}{|c|c|c|c|}
\hline \multicolumn{4}{|l|}{ Diatoms } \\
\hline Chaetoceras curvistis & 0.15 & $2.0-4.0$ & $0.037-0.075$ \\
\hline Nitzschia seriata & 0.015 & $0.15-0.2$ & $0.075-0.100$ \\
\hline Melosira granulata & $0.015-0.02$ & 0.15 & $0.075-0.133$ \\
\hline Rhizosolenia calcar avis & $0.01-0.02$ & $0.2-0.3$ & $0.033-0.100$ \\
\hline \multicolumn{4}{|l|}{ Zooplankton } \\
\hline Calanus helgolandicus & $0.006-0.007$ & 0.1 & $0.060-0.070$ \\
\hline Anomalocera \& Pontella & 0.004 & $0.2-0.25$ & $0.016-0.020$ \\
\hline Copepoda (sma1) & $0.06-0.07$ & $>3.0$ & $<0.023$ \\
\hline & $0.04-0.05$ & $0.4-0.5$ & $0.080-0.125$ \\
\hline Sagitta setosa \& S. euxina & 0.05 & $0.6-0.7$ & $0.071-0.083$ \\
\hline Pleurobranchia pileus & 0.0025 & 0.05 & $0.050-0.060$ \\
\hline
\end{tabular}


particles transported into the Black Sea during the Danube discharge peak would arrive at the trap site between May and September. This period coincides with the time of lowest storm activity in the area and also lowest river discharge of the Western Anatolian rivers; discharge of the Sakarya Nehri and Kocacay decreases by more than a factor of three (Fig. 6a).

The illite/montmorillonite ratio in the sediment trap material generally supports the conclusions drawn from the Ti/Al ratios of the same material. The lowest ratios exist in late winter and spring (February-April), resembling the illite/montmorillonite ratio of the Black Sea surface sediments in that area (Fig. 34), largely derived from local sources. In summer (June-September), the illite/montmorillonite ratio is on average about twice as high (Fig. 34), suggesting contribution of terrigenous matter from the Danube, which has a considerably higher ratio (Fig. 23). Correspondence between the illite/montmorillonite ratio in the fall of 1983 and the Ti/Al ratio in the fall of 1984, however, is not quite as good. Possible cause for this discrepancy could be a different storm pattern and thus resuspension intensity in the fall of those two years. Brewer and Spencer (1974) suggested that about $78 \%$ of the detrital river input to the Black Sea is deposited on the shelf areas and close to the river mouths, while $22 \%$ remains in suspension. Sporadic storms could also explain the relatively large range in illite/montmorillonite ratios in Phase II. 
The existing data for the Ti/A1 and illite/montmorillonite ratios, as well as the phase lag between peak discharge for the Western Anatolian rivers and the Danube, supports the conclusion that seasonal variability in the input of terrigenous matter from the Danube could be at least partially responsible for the higher $\mathrm{Ti} / \mathrm{Al}$ ratio for the May-September period in the sediment traps.

\subsubsection{Variability in grain size of the terrigenous matter}

$\mathrm{Ti}$ is preferentially concentrated in the coarser sediment fraction (Spears and Kanaris-Sotiriou, 1976; Migdisov, 1960; Sholkovitz, 1979), since $\mathrm{Ti}$ tends to be concentrated in heavier minerals more resistant to weathering. Ti-bearing minerals include ilmenite, and, to a lesser extent rutile, titanite, anatase, brookite, and sphene (e.g. Morad and A1dahan, 1982). Compared to argillaceous rocks (0-40\% quartz), Spears and Kanaris-Sotiriou (1976) measured a $37 \%$ higher Ti/A1 ratio in siltstones. Migdisov (1960) measured a $30 \%$ higher $\mathrm{Ti} / \mathrm{Al}$ ratio in sands and silts than in clays. However, the time period when the Ti/A1 ratio is lowest in the Black Sea sediment trap, October to March, represents the time period of highest surface water agitation due to storms and highest river discharge, when coarser grain size of particulate matter in the Black Sea rather than finer sizes should be present. In addition, the Anatolian shelf sediment should have a higher Ti/Al ratio 
then the sediment trap samples due to their coarser grain size. Thus, seasonal variability in grain size of the terrigenous matter does not appear to influence the observed annual variability in the Ti/Al ratio of the particulate matter in the southwestern Black Sea as observed in the sediment traps.

\subsubsection{Association of $\mathrm{Ti}$ with biogenic matter}

Data on the distribution of $\mathrm{Ti}$ in the water column are very sparse at present. The concentration in sea water is quite low. Griel and Robinson (1952) measured $\mathrm{Ti}$ concentrations of $<20 \mathrm{nmol} / \mathrm{kg}$ which was their detection limit. Average $\mathrm{Ti}$ concentration in the oceans is probably in the picomolar range (Bruland, 1987, pers. comn。). In the water column, $\mathrm{Ti}$ exists as hydrated species probably in the form of $\mathrm{Ti}(\mathrm{OH})_{4}^{0}$ rather than as $\mathrm{Ti}^{4+}$ (Bruland, 1983). Available information on the association of $\mathrm{Ti}$ with planktonic organisms is varied and inconclusive. The mechanisms by which $\mathrm{Ti}$ could conceivably be associated with organisms include incorporation into the skeletons of organisms, intake of aluminosilicates by zooplankton, and adsorption of $\mathrm{Ti}$ onto sinking particles. Biological uptake of $\mathrm{Ti}$ into the organic tissues of organisms is not likely based on biochemical constraints (Brewer, 1987, pers. comm.).

The occurrence of $\mathrm{Ti}$ in marine organisms has been reported by some 
authors (e.g. Griel and Robinson, 1952; Nicholls et al., 1959; Boström et a1., 1974; Matsunaga, 1982). Price and Doff (1981) tentatively suggested that the elevated $\mathrm{Ti}$ content in suspended particulate matter from the northeast Atlantic Ocean may be caused by incorporation into the skeletons of organisms. Biological uptake of $\mathrm{Ti}$ by phytoplankton was postulated by Sholkovitz and Price (1980) who studied the major-element chemistry of the suspended matter in the Amazon Estuary. In contrast, Thompson and Bowen (1969) studied coccolith ooze and found no enrichments in the calcite skeletons. Goldberg (1954) attributed most of the $\mathrm{Ti}$ found in marine organisms to ingestion of scavenged particles out of the water colum. Similarly, Goldberg and Arrhenius (1958) did not find unusually high $\mathrm{Ti} / \mathrm{Al}$ ratios in deep sea sediments with a high biogenic component. Simple digestion of aluminosilicates by zooplankton with subsequent excretion should have no impact on the Ti/Al ratio.

The elemental composition of the organic and skeletal fractions of phytoplankton was studied in detail by Martin and Knauer (1973) in samples from various sites in the Pacific Ocean. $T i$ was measured in silicious diatom frustules in phytoplankton group I (which was not considered contaminated by clays), with a $\mathrm{Ti} / \mathrm{Al}$ ratio of 0.19 . No $\mathrm{Ti}$ was detected in the organic fraction in this group.

In a second phytoplankton group, Martin and Knauer (1973) reported higher $T i$ and $A 1$ concentrations with a Ti/A1 ratio of 0.061 , but 
concluded that this group was probably contaminated with clay minerals. By comparing their uncontaminated data from phytoplankton group I to data reported by Vinogradova and Kovalskiy (1962) from the NW Black Sea and from Riley and Roth (1971) from the Irish Sea, Martin and Knauer (1973) concluded that the higher concentrations found by these authors were possibly a result of clay contamination. Contamination in the phytoplankton samples by Vinogradova and Kovalskiy (1962) is likely considering the relatively high $A 1$ content in the organisms (Table 11). The high concentrations of $\mathrm{Ti}$ in diatoms found by Griel and Robinson (1952) could possibly also have resulted from contamination during sampling.

In the southwestern Black Sea the dominant planktonic organisms are coccolithophorids (Emiliania huxleyi), diatoms, and, to a lesser extent, dinoflagellates and silicoflagellates (Benli, 1987; chapter 1). There are no radiolarians or foraminiferas. The absence of correlation between the $\mathrm{Ti} / \mathrm{Al}$ ratio and the $\mathrm{Si}_{\mathrm{blogen}} \mathrm{c} / \mathrm{Al}$ and carbonate/A1 ratios indicates that uptake of $\mathrm{Ti}$ into the skeletons of coccolithophorids and silicious phytoplankton is not an important process in the southwestern Black Sea. Coprecipitation of $T i$ with other metal sulfides is not likely since $T i$ has no important redox chemistry (Boyle, 1987, pers. comn. ).

A more 1ikely mechanism could be adsorption of $\mathrm{Ti}$ onto sinking organic matter. Adsorption is suggested by the correlation between the 
$C_{o r g} / A 1$ ratio and the $\mathrm{Ti} / \mathrm{Al}$ ratio which is significant at $\mathrm{p}<0.02$ ( $\mathrm{r}=0.43, \mathrm{n}=31,1,200 \mathrm{~m}$ traps) for the entire sampling period (Fig. 32). The significance leve1 increases to $\mathrm{p}<0.001(\mathrm{r}=0.65 ; \mathrm{n}=23$, $1,200 \mathrm{~m}$ traps) for the correlation between the two ratios from late summer to spring (July 1984 to March 1985, site BS, and June to August 1986, site BSC). During the late spring to early summer (May-July, 1984), the Ti/Al and Corg/Al ratios do not correspond as we11, suggesting the likelihood for another process responsible for the enrichment of $\mathrm{Ti}$.

In order to better evaluate the possibility of adsorption of $\mathrm{Ti}$ onto sinking organic matter, the time-series $\mathrm{Ti} / \mathrm{A} 1$ ratio was compared to the time-series metal/Al ratios for $\mathrm{Cu}$ and $\mathrm{Ni}$ which are known to be taken up biologically, namely $\mathrm{Cu}$ and $\mathrm{Ni}$ (e.g. Bowen, 1966; Calvert and Price, 1970; Riley and Chester, 1971; Chester et a1., 1978). These trace elements have been found concentrated in marine organisms because they are needed in metal-dependent enzyme systems of the organisms (e.g. Fowler and Knauer, 1986). Biological uptake of $\mathrm{Cu}$ in the Black Sea was also indicated by data from Zhorov et a1. (1983) who studied the concentration of $\mathrm{Cu}$ in the bottom sediments and observed a correspondence between high $\mathrm{Cu}$ content and high organic carbon content. In addition, the formation of metal sulfides could occur as a separate process (e.g. Brewer and Spencer, 1974; Suess, 1979; Luther et a1., 1980), apart from the possibility that metals may be associated with organic matter in the same manner. 
Correlation between the Cu/Al ratio and the Corg/Al ratio is significant $(r=0.83, p<0.001, n=31,1,200 \mathrm{~m}$ traps; Fig. 32). The correlation between the $\mathrm{Ni} / \mathrm{Al}$ and the $\mathrm{Corg} / \mathrm{Al}$ ratio is significant at $\mathrm{p}<0.01$ with $\mathrm{r}=0.53(\mathrm{n}=31,1,200 \mathrm{~m}$ traps; Fig. 32). These results indicate that $\mathrm{Cu}$ and $\mathrm{Ni}$ are closely associated with organic carbon. Correlations between $\mathrm{Ti} / \mathrm{Al}$ ratio and $\mathrm{Cu} / \mathrm{Al}$ and $\mathrm{Ni} / \mathrm{Al}$ ratios are $0.48(\mathrm{p}<0.01, \mathrm{n}=31)$ and $0.35(\mathrm{p}<0.05, \mathrm{n}=31)$, respective1y.

However, considering the observation that dissolved $\mathrm{Ti}$ occurs only in very low concentrations in the ocean, the enrichment factor for $\mathrm{Ti}$ onto organic matter due to adsorption would have to be considerably higher than for $\mathrm{Cu}$ and $\mathrm{Ni} . \mathrm{Cu}$ is concentrated in the oceans between about 0.5 and $6 \mathrm{nmol} / \mathrm{kg}, \mathrm{Ni}$ between about 2 and $12 \mathrm{nmol} / \mathrm{kg}$ (Bruland, 1983). In the Black Sea, Westerlund (1986) recently measured $5 \mathrm{nM}$ for $\mathrm{Cu}$ and $8 \mathrm{nM}$ for $\mathrm{Ni}$ in the oxic surface water, and $0.15 \mathrm{nM}$ for $\mathrm{Cu}$ and 9 $\mathrm{nM}$ for $\mathrm{Ni}$ in the anoxic deep water. In contrast, the concentration of $\mathrm{T} i$ in the oceans is less than $1 \mathrm{nM}$ (Bruland, 1987, pers. comm.), and thus is lower by several orders of magnitude.

The enrichment of trace metals on organic matter can be estimated, if we use the $\mathrm{Cu} / \mathrm{Al}, \mathrm{Ni} / \mathrm{Al}$, and $\mathrm{Ti} / \mathrm{Al}$ ratios of the suspended matter of the Western Anatolian rivers as a baseline. The "excess" content of e.g. Ti in the biogenic matter of the particle flux of the trap can then be calculated as 
"Excess" Ti f1uxMay-sep $=T i$ fluxMay-sep $-\underset{A 1}{-\left[-{ }_{A 1 v}\right.}$ * A1 fluxMay-sep $]$

F1ux is measured in $\mathrm{mg} \mathrm{m}^{-2} \mathrm{day}^{-1}$. If we calculate the biogenic particle flux as

Biogenic flux = Total flux - Lithogenic flux

it follows that

$$
\mathrm{Ti}_{\text {blog. matter }}(\mathrm{ppm})=\frac{\text { "Excess" Ti f1ux }}{\text { Biogenic flux }} * 1,000,000
$$

Results (Table 12) show that the "excess" Ti content during the May-September period is higher by about a factor of two compared to the "excess" $\mathrm{Cu}$ and $\mathrm{Ni}$ content. Considering that the dissolved Ti content in the ocean is typically several orders of magnitude lower than the dissolved $\mathrm{Cu}$ and $\mathrm{Ni}$ content, the enrichment factor of $\mathrm{Ti}$ must be several orders of magnitude higher compared to $\mathrm{Cu}$ and $\mathrm{Ni}$ in order to explain the "excess" Ti content in the May-September period in the biogenic matter in the sediment traps with the mechanism of adsorption onto organic matter. An exceptionally high enrichment factor for $\mathrm{Ti}$ is quite unlikely (Boyle, 1987, pers. comm.), unless the Black Sea contains considerably higher dissolved $\mathrm{Ti}$ concentrations than the world oceans. 
Table 12: "Excess" $\mathrm{Cu}, \mathrm{Ni}$, and $\mathrm{Ti}$ concentrations in the biogenic matter of the particle flux in the $1,200 \mathrm{~m}$ sediment trap at site BS for the time periods May/17/84-Sep/20/84 and Oct/23/84-Mar/22/85. Flux is measured in $\mathrm{mg} \mathrm{m}^{-2}$ day $^{-1}$. The negative "excess" Ti flux for the October-March period is a result of the slightly higher $\mathrm{Ti} / \mathrm{Al}$ ratio in the two suspended sediment samples of the Western Anatolian rivers used as a baseline rather than the particulate matter in sediment trap during this period.

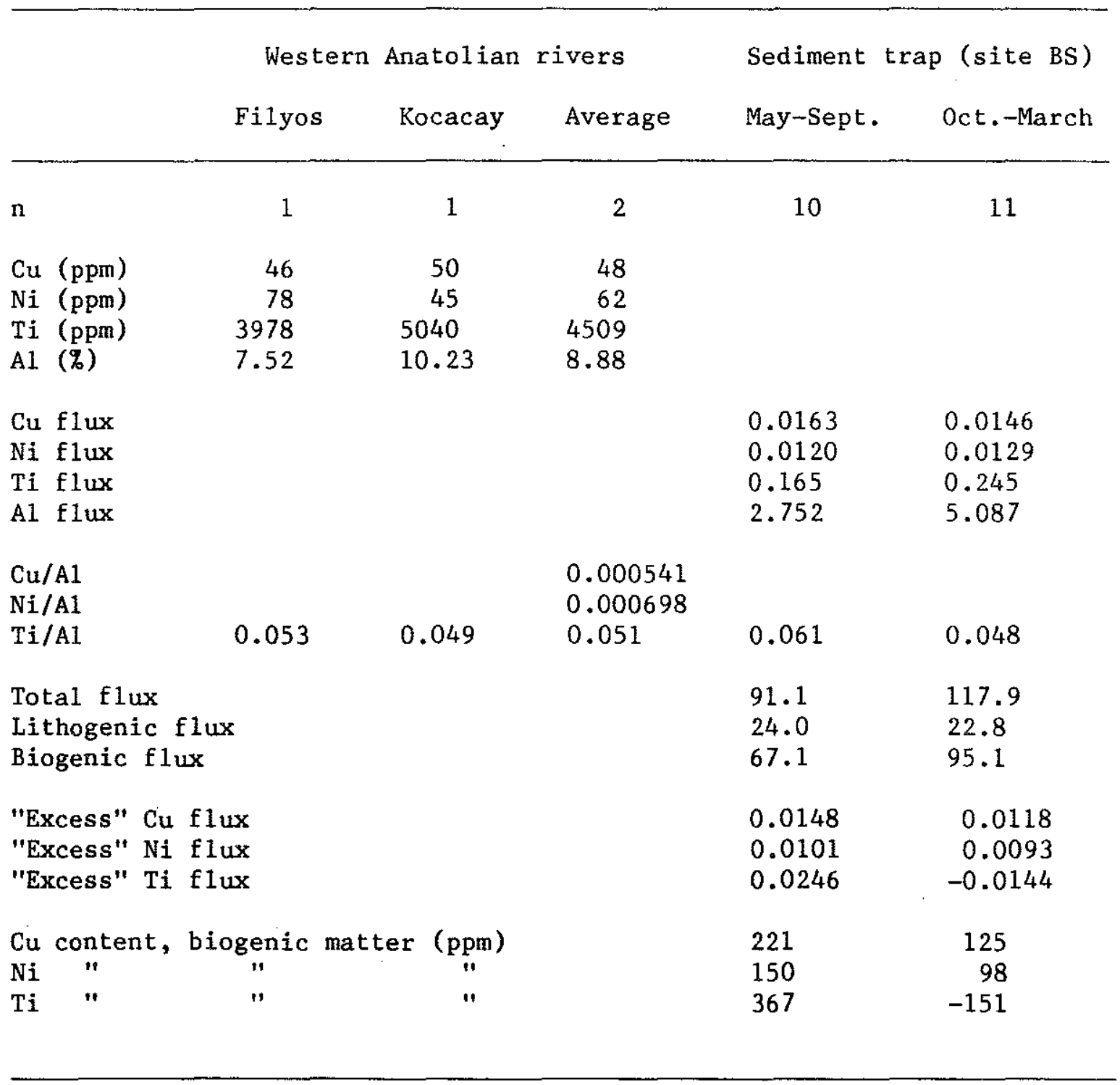


In conclusion, adsorption of $\mathrm{Ti}$ onto settling organic matter may contribute to the relatively higher $\mathrm{Ti}$ concentrations in the May-September period in the sediment trap samples as indicated by the significant correlation between the $\mathrm{C}_{\mathrm{org}} / \mathrm{Al}$ ratio and the $\mathrm{Cu} / \mathrm{Al}$ and $\mathrm{Ni} / \mathrm{Al}$ ratios. Biological uptake of $\mathrm{Ti}$ into the skeletons of organisms appears to be insignificant. The high Ti/Al ratio from May to July, 1984, however, cannot be conclusively linked to biological processes from the available data. Adsorption as exclusive mechanism to explain the relatively higher $\mathrm{Ti}$ concentrations is not likely, given the high enrichment factor required.

3.4.4. Other causes

There are other causes reported in the literature for elevated Ti/A1 ratios. Migdisov (1960) observed a relationship between c1imate and the $\mathrm{Ti} / \mathrm{Al}$ ratio. Typically, the $\mathrm{Ti} / \mathrm{Al}$ ratio in sands from humid climates was higher due to preferential chemical weathering of the aluminosilicates compared with the more resistant $\mathrm{TiO}_{2}$ minerals. This relationship was not observed in finer clastics, however, and probably does not apply to the suspended matter in the Black Sea. Boyle (1983) found a positive correlation between the $\mathrm{Ti} / \mathrm{Al}$ ratio and the accumulation rate of aluminosilicates in the Peru current region and attributed the higher ratio to increased eolian transport during colder climates, which could be related to source area or grain size. The 
variability in his data in the Ti/Al ratio, however, was one order of magnitude lower than the variability observed in the Black Sea. In addition, due to the close proximity of the Black sea sediment trap sites to river sources, eolian input as a terrigenous particle source is relatively insignificant.

\subsection{CONCLUSTONS}

The $T i$ and $A 1$ content in the particle flux in the southwestern Black Sea is very highly correlated. However, the Ti/A1 ratio varies significantly with season. The ratio is higher from May to September and lower from October to March. At site BS it is higher on average by $30 \%$. There are two hypotheses that could explain the seasonal variability in the $\mathrm{Ti} / \mathrm{Al}$ ratio.

The most likely explanation for the higher $\mathrm{Ti} / \mathrm{Al}$ ratio in the May-September period is a higher contribution of Danube river particulates. This conclusion is supported by higher Ti/Al ratios from relevant shelf and river sediments, time-series illite/montmorillonite ratios in the trap samples, and the phase lag in the discharge peak between the Western Anatolian rivers and the Danube.

An alternative hypothesis to explain the higher $\mathrm{Ti} / \mathrm{Al}$ ratio in the May-September period could be adsorption of $\mathrm{Ti}$ onto sinking organic 
matter. This hypothesis is suggested by the correlations between the $\mathrm{C}_{\text {org }} / \mathrm{Al}$ and the $\mathrm{Ti} / \mathrm{Al}, \mathrm{Cu} / \mathrm{Al}$, and $\mathrm{Ni} / \mathrm{Al}$ ratios during the May-September period. However, the enrichment factor needed for $\mathrm{Ti}$ enrichment by adsorption is likely to be too high.

Therefore, the Ti/Al ratio of the particulate matter in the western Black Sea may represent a useful tracer for monitoring the dispersal and relative importance of suspended matter from the Danube, seasona11y and regionally, in Black Sea water. More time-series data of the particulate matter in the Black Sea from time-series samples closer to the Danube river mouth would be useful to further refine this conclusion. The Ti/A1 ratio as tracer for the Danube particulates would be important to understand the dispersal pattern of geochemica1 processes in the Black Sea related to terrigenous particles, e.g. the dispersal pattern of particle-reactive radionuclides that were carried into the Black Sea by the Dnepr after the Chernobyl accident. Given that the Ti/A1 ratio in terrigenous matter is dependent on source area, extrapolation of the results from the relatively well-studied Black Sea to the open ocean could help to identify seasonal as well as long-term changes in terrigenous source areas or circulation, and thereby establish the $\mathrm{Ti} / \mathrm{Al}$ ratio as a useful tracer in oceanography as well as paleoceanography. 
CONCLUSIONS OF THESIS RESEARCH

Biogenic particles in the western Black Sea are mostly supplied by coccolithophorids of the species Emiliania huxleyi, diatoms, and silicoflagellates. Dominant terrigenous particles source for the western Black Sea is the Danube, although in the nearshore southwestern Black Sea terrigenous matter is mostly supplied by local Anatolian rivers. Seasonally, the influence of terrigenous particles from the Danube can be traced also in the southwestern Black Sea, using the Ti/AI ratio. The Ti/A1 ratio may represent a useful tracer of terrigenous sources also in other oceanic environments.

Resuspension of particles from the shelf is an important mechanism for the transport of particles to their final site of deposition. In the southwestern Black Sea, resuspension, which was traced with the $\mathrm{Corg} /\left(\mathrm{CaCO}_{3}+\mathrm{Si}_{\mathrm{b}} \circ \mathrm{g}\right)$ ratio, occurs during the storm season from late fall to spring. Resuspension of coccoliths from the Danube shelf is responsible for the about 5 times higher particle flux in the central part of the western Black Sea as compared to the southwestern Black Sea. Once removed from the surface water, particles settle at a rate of $115 \pm 70 \mathrm{~m} /$ day. Particles settle twice as fast during the stormy winter and spring seasons $(125 \mathrm{~m} /$ day $)$ than during summer and fall $(65 \mathrm{~m} /$ day $)$. The $\mathrm{Corg}_{\mathrm{g}} /\left(\mathrm{CaCO}_{3}+\mathrm{Si}_{\mathrm{b}} \circ \mathrm{g}\right)$ ratio can possibly also be applied to other areas in the Black Sea to identify resuspended biogenic matter in the particle flux. 
The particle flux varies considerably tempora11y, on short time scales such as the biweekly sampling intervals, as well as on long time scales, such as the 5,000 year long core record. On an annual scale, the particle flux in the southwestern Black sea can be grouped into three phases based on its dominant particle supply mechanism: Phase I (June-0ctober) - coccolithophorid bloom, Phase II (November-January) resuspension of particles from the shelf, and Phase III (February-May) river input and bloom of diatoms and silicoflagellates. Over the last 5,000 years the terrigenous paleoflux remained about constant while the carbonate paleoflux increased by a factor of 11 at $1,000 \mathrm{B.P}$. due to the establishment of Emiliania huxleyi, which increased the total paleoflux by a factor of about 5 since that time. White laminae in the basinal sediments are linked to the summer bloom and the subsequent resuspension period (Phases I \& II). Black laminae are deposited during periods of high river discharge (Phase III). 
FUTURE WORK

There are several reasons that make the Black Sea an excellent environment for unravelling the interrelated biogeochemical parameters that play an important role in the deposition of particles from source to burial. Such reasons include the confined nature of the Black Sea basin with limited parameters in the particle supply, as well as the anoxic deep water which preserves the annual signature in the sediment record.

The Black Sea thereby serves as a key to better understand the detailed sedimentation in other oceanic environments, specifically in anoxic paleooceans where annual particle flux patterns may also have been preserved. Among the range of future studies that could be suggested based on this work, some of the more important ones include the following, of which some have been proposed and accepted for the upcoming $R / V$ KNORR cruise to the Black Sea in 1988.

1) Given the considerable spatial variability in the particle flux in the Black Sea and given the absence of reliable time-series data on the biocoenocis and particle flux for most of the Black Sea, a critical set of data is missing for the understanding of the Black Sea as a biogeochemical unit. Such data are important, however, for the refined modelling of the annual sedimentation pattern, as well as also for chemical budget calculations and biological variability studies in this 
unique environment.

2) The interrelationship between the particle flux in the present with the flux of the past should be investigated simultaneously at several sites in the Black Sea in an integrated chemical, microbiological, and sedimentological study, to better understand the development of the Black Sea as an anoxic environment.

3) The study of the paleoflux could be applied to other anoxic environments with laminated sediment records using some of the techniques explored in this work. Modern anoxic environments include the African lakes and the continental slope of the Arabian Sea; ancient environments include the sedimentary records of anoxic paleooceans from the Cretaceous and the Lower Paleozoic.

4) The Ti/Al ratio should be studied further in time-series samples from the Black Sea as well as ofher marine environments in order to establish it as a potential tracer for terrigenous input. 
$-177-$ 
$-173-$ 


\section{REFERENCES}

Amorocho, J. and J.J. DeVries, 1981, Reply on 'A new evaluation of the wind stress coefficient over water surfaces': J. Geophys. Res., v. 86 , p. 4308 .

Amorocho, J. and J.J. DeVries, 1980, A new evaluation of the wind stress coefficient over water surfaces: J. Geophys. Res., v. 85, p. 433-442.

Androsov, N.I., 1890, Predvaritye1'nyi otchet ob uchastii v Chernomorskoy glubokomernoy ekspeditsii $1890 \mathrm{~g}$ (Preliminary accounts of participation in the Black Sea deepwater expedition of 1890): Izv. Russk. Geogr. Obshch., v. 26, p. 398-409.

Andrusov, N.I., 1893, Einige Resultate der Tiefseeuntersuchungen im Schwarzen Meere: Wien, Mitt. Geogr. Gese11.

Arkhangel'skii, A.D., and N.M. Strakhov, 1927, Ob osadkakh Chernogo morya $i$ ikh znach enii $v$ poznanii osadochnykh gornykh porod (On the Black Sea sediments and their significance in sedimentology): Moskov. Obshch. Ispytateley Prirody Byul1. Otdel. Geol., v. 5, no. $3-4$, p. $199-289$. 
Arkhangel'skiy, A.D. and Strakhov, N.M., 1932, Geologicheskoye istoriya Chernogo morya (Geological history of Black Sea): Obshch. Ispytateley Prirody Byul1. Otdel. Geol., v. 10, no. 1: 3-104.

Arkhange1'skiy, A.D. and Strakhov, N.M., 1938, Geologicheskoye stroyeniye $i$ istoriya razvitiya Chernogo morya (Geological structure and history of the evolution of the Black Sea), Moscow-Leningrad. Akad. Nauk SSSR Izv.

Asper, V.L., 1986, Accelerated settling of marine particulate matter by 'marine snow' aggregates. Ph.D. Thesis. MIT/WHOI, WHOI-96-12.

Aybulatov, N.A. and Z.T. Novikova, 1984, Quantitative distribution of suspended matter in shelf waters of the Black Sea: Oceanology, v. 24 , p. $721-726$.

Barnard, L.A. and K.A. Fanning, 1976, Black Sea sediment-water interface; physical and chemica1 characteristics: EOS, v. 57, p. 3 .

Baucells, M.G. Lacort, and M. Roura, 1983, Determinacion de A1, Fe, Mg, Ti y Mn en sedimentos marinos. Estudio comparativo de las tecnicas de plasma de induccion (ICP) absorcion atomica (AAS) y espectrografia de emision (OES): Anales de Quimica, v. 81, p. 48-55. 
Baumgartner, T., V. Ferreira-Bartrina, H. Schrader, and A. Soutar, 1985, A 20-year varve record of silicious phytoplankton variability in the Central Gulf of California: Mar. Geol., v. 64, p. 113-129.

Belogorskaya, E.V., 1959, Nekotorye dannye o raspredelenii i kolichestvennom razvitii fitoplanktona $v$ Chernom More (Some data on distribution and quantitative development of phytoplankton in the Black Sea): Sevast. Bio1. Stantsii Trudy, v. 12, p. 71-101.

Benli, H., 1987, Investigation of plankton distribution in the Southern Black Sea and its effects on the particle flux; in: E.T. Degens, E. Izdar, and S. Honjo, eds., Particle flux in the ocean, Mitteil. Geo1. Pa1. Inst., Univ. Hamburg, v. 62 (in press).

Berry, W.B.N. and P. Wilde, 1978, Progressive ventilation of the oceans - an explanation for the distribution of he Lower Paleozoic black shales: Am. J. Sci., v. 278, p. 257-275.

Biscaye, P.E., 1965, Mineralogy and sedimentation of recent deep-sea clays in the Atlantic Ocean and adjacent seas and oceans: Geol. Soc. Am. Bul1., v. 76, p. 803-832.

Bol'shakov, V.S., 1970, Transformatsiya rechnykh vod Chernogo morya (Transformation of river waters in Black Sea): Kiev, Izd. "Naukova Dumka". 
Boström, K., 0. Joensuu, and I. Brohm, 1974, P1ankton: its chemical composition and its significance as a source of pelagic sediments: Chem. Geo1., v. 14, p. 255-271.

Bowen, H.J.M, 1966, Trace Elements in Biochemistry, Academic Press, London.

Boyle, E.A., 1983, Chemical accumulation variations under the Peru Current during the past 130,000 years: J. Geophys. Res., v. 88, p. 7667-7680.

Brewer, P.G., Y. Nozaki, D.W. Spencer, and A.P. Fleer, 1980, Sediment trap experiments in the deep North Atlantic: isotopic and elemental fluxes: J. Mar. Res., v. 38, p. 703-728.

Brewer, P.G. and D.W. Spencer, 1974, Distribution of some trace elements in Black Sea and their flux between dissolved and particulate phases; in: Degens, E.T. and D.A. Ross (eds.), 1974, The Black Sea -geology, chemistry, and biology, Am. Asso. Petr. Geol., Mem. 20, p. 137-143.

Broecker, W.S., and T.-H. Peng, 1982, Tracers in the Sea, Lamont-Doherty Geological Observatory Publication, Columbia University, New York, 690p. 
Bruland, K.W., 1983, Trace elements in sea-water; in: Riley, J.P. and R. Chester, eds., Chemical Oceanography, v. 8, p. 157-220.

Buesseler, K.O., H.D. Livingston, S. Honjo, B.J. Hay, S.J. Manganini, E. Degens, V. Ittekkot, E. Izdar, and T. Konuk, 1987, Chernoby1 radionuclides in a Black Sea sediment trap: A preliminary report: Nature (in press).

Bukry et al., 1970, Geological significance of coccoliths in fine-grained carbonate bands of postglacial Black Sea sediments: Nature, v. 226 , p. 156-1587.

Bukry, D., 1974, Coccoliths as paleosalinity indicators - evidence from the Black Sea. in: Degens, E.T. and D.A. Ross (eds.), 1974, The Black Sea - geology, chemistry, and biology, Am. Asso. Petr. Geol., Mem. 20, p. 353-363.

Calvert, S.E., J.S. Voge1, and J.R. Southon, 1987, Carbon accumulation rates and the origin of the Holocene sapropel in the Black Sea: Geology (in press).

Calvert, S.E. and M.R. Fontugne, 1987, Stable carbon isotopic evidence for the origin of the organic matter in the Holocene Black Sea saprope1: (in press) 
Calvert, S.E, and N.B. Price, 1970, Minor metal content of recent organic-rich sediments off South West Wales: Nature, v. 227, p. $593-595$.

Caraco, N. and S. Honjo, 1987, Sedimentation of algal and bacterial pigment in the Black Sea: Implications for the origins of black sediment varves (submitted to Science).

Chester, R. and S.R. Aston, 1976, The geochemistry of deep-sea sediments; in: Riley, J.P. and R. Chester, eds., Chemical Oceanography, v. 6 , p. 281-390.

Chester, R.A. Griffiths, and J.H. Stoner, 1978, Minor metal content of surface seawater particulates and organic-rich shelf sediments: Nature, v. 275, p. 308-309.

Curry, W.B. and G.P. Lohmann, 1988, Reconstructing past particle fluxes in the Tropical Atlantic: (in prep.)

Degens, E.T., 1974, Cellular processes in Black Sea sediments, in: Degens, E.T. and D.A. Ross, eds., 1974, The Black Sea -geology, chemistry, and biology, Am. Asso. Petr. Geo1., Mem. 20, p. 296-307. 
Degens, E.T., V. Ittekkot, S. Kempe, V. Asper, and S. Manganini, 1984, Sedimentation mariner Schwebstoffe, untersucht mit Hilfe von Sedimentfallen: Unpub1, progress report, Universität Hamburg, F.R. Germany, 30p.

Degens, E. and Ross, D., eds., The Black Sea - Geology, Chemistry, and Biology. Amer. Assoc. Pet. Geol., Memo. 20, 633p.

Degens, E.T. and Stoffers, P., 1976, Stratified waters as a key to the past: Nature, v. 263, p. 22-26.

Degens, E.T. and P. Stoffers, 1980, Environmental events recorded in Quaternary sediments of the Black Sea: J. geol. Soc. London, v. 137, p. $131-138$.

Degens, E.T., W. Michaelis, C. Garrasi, K. Mopper, S. Kempe, and V.A. Ittekkot, 1980, Warven-Chronologie und früdiagenetische Umsetzungen organischer Substanzen holozäner Sedimente des Schwarzen Meeres: N. Jb. Geo1. Paläont. Mh., v. 5, p.65-86.

Degens, E.T., Stoffers, P., Golubic, S. and Dickman, M.D., 1978, Varve chronology: estimated rates of sedimentation in the Black Sea Deep Basin; in: Ross, D.A., Neprochnov, Y.P., et al., eds., Initial Reports of the Deep Sea Drilling Project, v. 42, Part 2, Washington D.C., U.S. Government Printing office, p. 499-508. 
Demaison, G.J. and G.T. Moore, 1980, Anoxic environments and oil source bed genesis: Am. Asso. Petr. Geo1. Bu11., v.64, p.1179-1209.

Deuser, W.G., 1971, Organic-carbon budget of the Black Sea: Deep Sea Res., v. 18, p. 995-1004.

Deuser, W.G., 1972, Late-Pleistocene and Holocene history of the Black Sea as indicated by stable isotope studies: J. Geophys. Res., v. 77, p. $1071-1077$.

Deuser, W.G., 1974, Evolution of anoxic conditions in Black Sea during Holocene; in: Degens, E. and Ross, D., eds., The Black Sea geology, chemistry, and biology, Amer. Asso. Petrol. Geol. Memo. 20, p. $133-136$.

Deuser, W.G., 1974, Evolution of anoxic conditions in Black Sea during Holocene; in: Degens, E.T. and D.A. Ross, eds., The Black Sea Geology, Chemistry, and Biology. Amer. Assoc. Pet. Geo1., Memo. 20: $133-136$.

Dickman, M and I. Artuz, 1978, Mass mortality of photosynthetic bacteria as a mechanism for dark laminae formation in sediments of the Black Sea, Nature, v. 275, p. 191-195. 
Dymond, J., K. Fischer, M. Clauson, R. Cobler, W. Gardner, M.J.

Richardson, W. Berger, A. Soutar, and R. Dunbar, 1981, A sediment trap intercomparison study in the Santa Barbara Basin: Earth Planet. Sci. Lett., v. 53, p. 409-418.

Eggimann, D.W., F.T. Manheim, and P.R. Betzer, 1980, Dissolution and analysis of amorphous silica in marine sediments: J. Sed. Petro1., v. 50 , p. $215-225$.

Filippov, D.M., 1968, Circulation and Structure of the waters of the Black Sea, Nauka, Moskow, 260p., (in Russian).

Finenko, Z.Z., 1967, Pervichnaya produktsiya yuzhnykh morei (Primary production in southern seas); in: Vodyanitskii, V.A., ed., Voprosy biookeanografii (Problems of bio-oceanography), Kiev, Izd. Naukova Dumka".

Fischer, A.G., and M.A. Arthur, 1977, Secular variations in the pelagic realm, in: Cook,H.E., and P. Enos, eds., Deep marine carbonate environments: SEPM Special Publication 25, p. 19-50.

Floyd, M.A., V.A. Fasse1, and A.P. D'Silva, 1980, Computer-controlled scanning monochromator for the determination of 50 elements in geochemical and environmental samples by inductively coupled plasma-atomic emission spectrometry: Anal. Chem., v. 52, p. 2168-2173. 
Force, E., 1984, A relation among geomagnetic reversals, seafloor spreading rate, paleoclimate, and black shale: EOS, p. 18-19.

Fowler, S.W. and G.A. Knauer, 1986, Role of large particles in the transport of elements and organic compounds through the oceanic water column: Prog. Oceanogr., v. 16, p. 147-194.

Gardner, W.D., K.R. Hinga, and J. Marra, 1983, Observations on the degradation of biogenic material in the deep ocean with implications on accuracy of sediment trap fluxes: J. Mar. Res., v. 41, p. 195-214.

Georgescu, I.I., S. Lupan, M. Salagean, and M. Oancea, 1973, Chemica1 composition of Danube water, sea water, algae and sediments of the B1ack Sea: Thalassia Jugos1., v. 9, p. 87-99.

Glenn, C.R. and M.A. Arthur, 1985, Sedimentary and geochemical indicators of productivity and oxygen contents in modern and ancient basins: The Holocene Black Sea as the "type" anoxic basin: Chemical Geology, v. 48, p. 325-354.

Goldberg, E.D., 1954, Marine geochemistry. 1. Chemical scavengers of the sea: J. Geo1., v. 62, p. 249-265.

Goldberg, E.D. and G.0.S. Arrhenius, 1958, Chemistry of Pacific pelagic sediments: Geochim. Cosmochim. Acta, v. 13, p. 153-212. 
Grasshoff, K. 1975, The hydrochemistry of landlocked basins and fjords, in: Riley, J.P. and G. Skirrow, eds., Chemical Oceanography, 2nd ed., New York, Academic Press, p. 456-593.

Griel, J.V. and R.J. Robinson, 1952, Titanium in sea water: J. Mar. Res., v. 11, p. 173-179.

Hirst, D.M., 1974, Geochemistry of sediments from eleven Black Sea cores; in: Degens, E.T. and D.A. Ross, The Black Sea - geology, chemistry, and biology, Am. Asso. Petrol. Geol. Mem. 20, p. 430-455.

Holland, H.D., 1984, The chemical evolution of the atmosphere and oceans; Princeton Series in Geochemistry, Princeton University Press, Princeton, New Jersey, 582p.

Holligan, P.M., M. Viollier, D.S. Harbour, P. Camus and M. Campagne-Phillips, 1983, Satellite and ship studies of coccolithophore production along a continental shelf edge: Nature, $304,5924: 339-342$.

Honjo, S., 1980, Material fluxes and modes of sedimentation in the mesopelagic and bathypelagic zones: J. Mar. Res., v. 38, p. 53-97.

Honjo, S., 1982, Seasonality and interaction of biogenic and lithogenic particulate flux at the Panama Basin: Science, v. 218, p. 883-884. 
Honjo, S., 1984, Study of ocean fluxes in time and space by bottom-tethered sediment trap arrays: A recommendation; in: Global Ocean Flux Study, Proceedings of a workshop, Sept 10-14, 1984, Nat. Acad. Press, p. 306-324.

Honjo, S. and K.W. Doherty, 1987, Large aperture time-series oceanic sediment traps; design objectives, construction and application: Deep Sea Research (in press)

Honjo, S., K.W. Doherty, Y.C. Agrawal, and V.L. Asper, 1984, Direct optical assessment of large amorphous aggregates (marine snow) in the deep ocean: Deep Sea Res., v. 31, p. 67-76.

Honjo, S., B.J. Hay, S.J. Manganini, and V.L. Asper, 1987, Seasona1 cyclicity of lithogenic particle fluxes at a Southern Black Sea sediment trap station; in: E.T. Degens, E. Izdar, and S. Honjo, eds., Particle flux in the ocean, Mitteil. Geol. Pal. Inst., Univ. Hamburg, v. 62 (in press).

Honjo, S., S.J. Manganini, V.L. Asper, B.J. Hay, and A.L. Karowe, 1987, Particle Fluxes, South Central Black Sea: 1982-1985 (Black Sea sedimentation data file, v. 1), Woods Hole Oceanographic Institution Technical Report WHOI-87-__ and Piri Reis International Contribution Series publication No. 3, 106pp (in press). 
Honjo, S., S.J. Manganini, and J.J. Cole, 1982a, Sedimentation of biogenic matter in the deep ocean; Deep-Sea Research, v. 29, p. 609-625.

Honjo, S., S.J. Manganini, and L.J. Poppe, 1982b, Sedimentation of lithogenic particles in the deep ocean: Marine Geology, v. 50, p. 199-220.

Hsu, S.A., 1981, Models for estimating of fshore winds from onshore meteorological measurements: Boundary-Layer Meteorology, v. 20, p. 341-351.

Ittekkot, V., S. Kempe, V. Asper, and S. Manganini, 1984, Sedimentation mariner Schwebstoffe, untersucht mit Hilfe von Sedimentfallen Kennzeichen 525-3891-MFG 004: Geologisches Paläontologisches Institut, Universität Hamburg, unpublished report.

Izdar, E., T. Konuk, S. Honjo, V. Asper, S. Manganini, E.T. Degens, V. Ittekkot, and S. Kempe, 1984, First data on sediment trap experiment in Black Sea deep water: Naturwissenschaften, v. 71, p. 478-479.

Izdar, E., T. Konuk, V. Ittekkot, S. Kempe, and E.T. Degens, 1987, Particle flux in the Black Sea: Nature of organic matter; in: E.T. Degens, E. Izdar, and S. Honjo, eds., Particle flux in the ocean, Mittteil. Geol. Pal. Inst., Univ. Hamburg, v. 62 (in press). 
Jouse, A.P. and V.V. Mukhina, 1978, Diatom units and the paleogeography of the Black Sea in the Late Cenozoic, in: Ross, D.A. and Y.P. Neprochnov, et a1., eds., 1978, Init. Rep. of the Deep Sea Drilling Program, Leg 42B, U.S. Gov. Print. Off., p. 903-950.

Kempe, S., 1985, Sediment trapping in the Black Sea: Terra cognita, v. 5 , p. 70 .

Kempe, S., V. Ittekkot, H. Nies, E.T. Degens, K.0. Buesseler, H. Livingston, S. Honjo, B. J. Hay, S. Manganini, E. Izdar, and T. Konuk, 1987, Comparison of Chernobyl nuclide deposition in the Black Sea and in the North Sea; in: E.T. Degens, E. Izdar, and S. Honjo, eds., Particle flux in the ocean, Mittteil. Geol. Pal. Inst., Univ. Hamburg, v. 62 (in press).

Knauer, G.A., J.H. Martin, and K.W. Bruland, 1979, Fluxes of particulate carbon, nitrogen, and phosphorus in the upper water column of the northeast Pacific: Deep Sea Res., v. 26A, p. 97-108.

Kovaleva, T.M., 1969, Sezonnie izmeniya fitoplanktona $v$ neriticheskoi zone Chernogo morya. (Seasonal variation of phytoplankton in the neritic zone of the Black Sea): Biologiya morya, v. 17, p. 18-31. 
Luther, G.W. III, A.L. Meyerson, J.J. Krajewski, and R. Hires, 1980, Metal sulfides in estuarine sediments:J. Sed. Petr., v. 50, p. $1117-1120$

Martin, J.H. and G.A. Knauer, 1973, The elemental composition of plankton: Geochim. Cosmochim. Acta, v. 37, p. 1639-1653.

Matsunaga, K., 1982, An estimation of allochthonous and autochthonous organic matter of the fresh sediments on the basis of the $\mathrm{Ti}$ content: Jap. J. Limn., v. 43, p. 113-120.

Migdisov, A.A., 1960, On the titanium/aluminium ratio in sedimentary rocks: Geochemistry U.S.S.R (English translation), v. 2, p. 178-194.

Milliman, J.D., R.C. Beardsley, Y. Zuo-Sheng, and R. Limeburger, 1985a, Modern Huanghe-derived muds on the outer shelf of the East China Sea: identification and potential transport mechanisms: Cont. Shelf Res., v. 4, p. 175-188.

Milliman, J.D., S. Huang-Ting, Y. Zuo-Sheng, and R.H. Meade, 1985b, Transport and deposition of river sediment in the Changjiang estuary and adjacent continental shelf: Cont. Shelf Res., v. 4, p. 37-45.

Morad, S. and A.A. Aldahan, 1982, Authigenesis of titanium minerals in two Proterozoic sedimentary rocks from southern and central Sweden: J. Sed. Petrol., v. 52, p. 1295-1305. 
Morozova-Vodyanitskaya, N.V., 1948, Fitoplankton V Chernom morya. I.

Fitoplankton $v$ rayona Sevastopol' i obshchii obzor fitoplankton Chernogo morya (Phytoplankton in Black Sea. I. Phytoplankton in the Sevastopo1 area and survey of phytoplankton in Black Sea): Sevastopo1 Biol. Station Trudy, v. 6, p. 39-172.

Miiller, P.J., H. Erlenkeuser, and R. von Grafenstein, 1983, Glacial-interglacial cycles in oceanic productivity inferred from organic carbon contents in eastern North Atlantic sediment cores: Thiede, J. and E. Suess, eds., Coastal Upwelling - its Sediment Record, Part B: Sedimentary Records of Ancient Coastal Upwelling, P1enum Press, New York, p. 365-398.

Miiller, G. and P. Stoffers, 1974, Mineralogy and Petrology of Black Sea sediments, in: Degens, E.T. and D.A. Ross (eds.), 1974, The Black Sea -geology, chemistry, and biology, Am. Asso. Petr. Geol., Mem. 20 , p. 200-248.

Murray, J., 1900, On the deposits of the Black Sea: Scot. Geogr. Mag., v. 16, p. $673-702$.

Neumann, G. 1942, Die absolute Topographie des physikalischen Meeresniveaus und die öberflächenströmungen des Schwarzen Meeres: Ann. Hydr. Marit. Meteor1., v. 70, p. 265-282. 
Neuymin, G.G., 1973, Optical studies in the Black Sea waters; in: Materials of Symposium on the Studies of the Black and Mediterranean Seas, Naukova dumka, Kiev, p. 81-88 (in Russian).

Nicholls, G.D., H. Cur1, and V.T. Bowen, 1959, Spectrographic analysis of marine plankton: Limnol. Oceanogr, , v. 4, p. 472-478.

Poppe, J.L. and J.C. Hathaway, 1986, Procedure for X-ray powder diffraction analysis: Report to the Env. Protection Agency, USGS-EPA IAG DW14931699-01-0, 37p.

Price, N.B. and D.H. Doff, 1982, Distribution et geochimie de suspensions particulaires en aluminium, fer et titanium dans 1,Atlantique Nord-est: Bu1l Inst. Geol. Bassin d'Aquitaine, Bordeaux, v. 32., p. 311-323.

Pyzik, G.K., 1968, Studies of phytoplankton in the Black Sea from 1953-1963; in: Biological Studies of the Black sea, Nauka, Moskow, p. 30-39 (in Russian).

Riley, J.P. and R. Chester, 1971, Introduction to Marine Chemistry, Academic Press, 465p. 
Riley, J.P. and I. Roth, 1971, The distribution of trace elements in some species of phytoplankton grown in culture: 1. Mar. Biol. Ass. U.K., v. 51 , p. $625-627$.

Rodo1fo, K.S., B.A. Buss, and 0.H. Pilkey, 1971, Suspended sediment increase due to Hurricane Gerda in continental shelf waters off Cape Lookout, North Carolina: J. Sed. Petr., v. 41, p. 1121-1125.

Ross, D.A. and E.T. Degens, 1974, Recent sediments of the Black Sea, in: Degens, E.T. and D.A. Ross, eds., 1974, The Black Sea - geology, chemistry, and biology, Am. Asso. Petr. Geol. Mem. 20, p. 183-199.

Ross, D.A., Neprochnov, Y.P., et a1., 1978, Initial Reports of the Deep Sea Drilling Project, v. 42, Part 2, Washington D.C., U.S. Government Printing office.

Ross, D.A. E. Uchupi, K.E. Prada, and J.C. MacIlvaine, 1974, Bathymetry and microtopography of Black Sea. In: Degens, E.T. and Ross, D.A., eds., 1974, The Black Sea - geology, chemistry and biology: Amer. Asso. Petro1. Geo1. Mem. 20, p. 1-10.

Roukhiyainen, M.I., 1975, On the seasonal dynamics of phytoplankton in the Black Sea; in: Biology of the Sea, Naukova dumka, Kiev, p. 3-15 (in Russian). 
Ryan, W.B.F. and M.B. Cita, 1977, Ignorance concerning episodes of ocean-wide stagnation: Marine Geology, v. 23, p. 197-215.

Schlanger, S.0. and H.C. Jenkyns, 1976, Cretaceous anoxic events: causes and consequences: Geol. Mijnb., v. 55, p. 179-184.

Schrader, H.-J., 1978, Quaternary through Neogene history of the Black Sea, deduced from the paleoecology of diatoms, silicoflagellates, ebridians, and chrysomonads; in: Ross, D.A., Neprochnov, Y.P., eds., Initial Reports of the Deep Sea Drilling Project, Washington, D.C., U.S. Gov. Print. Off., v. 42B, p. 789-901.

Sethuraman, S. and G.S. Raynor, 1975, Surface drag coefficient dependence on the aerodynamic roughness of the sea: J. Geophys. Res., v. 80 , p. 4983-4988.

Shimkus, K.M., V.V. Mukhina, and E.S. Trimonis, 1973, On the role of diatoms in the Late Quaternary sedimentation in the Black Sea: Oceanology, v. 13, p.882-887.

Shimkus, K.M. and E.S. Trimonis, 1974, Modern sedimentation in Black Sea, in: Ross, D.A. and E.T. Degens, eds., The Black Sea - geology, chemistry, and biology, Am. Asso. Petr. Geol. Mem. 20, p. 249-278. 
Sholkovitz, E.R., 1979, Chemical and physical processes controlling the chemical composition of suspended material in the River Taj estuary: Estuarine and Coasta1 Mar. Sci., v. 8, p. 523-545.

Sholkovitz, E.R. and N.B. Price, 1980, The major-element chemistry of suspended matter in the Amazon Estuary: Geochim. Cosmo. Acta, v. 44, p. $163-171$.

Sorokin, Yu.I., 1982, The Black Sea; in: Ketchum, B.H., ed., Estuaries and Enclosed Seas, Ecosystems of the World, v. 26, E1sevier Sci. Pub1., New York, 500p.

Spears, D.A. and R. Kanaris-Sotiriou, 1976, Titanium in some carboniferous sediments from Great Britain: Geochim. Cosmochi. Acta, v. 40, p. $345-351$.

Spencer, D.W., P.G. Brewer, and P.L. Sachs, 1972, Aspects of the distribution and trace element composition of suspended matter in the Black Sea: Geochim. Cosmo. Acta, v. 36, p. 71-86.

Strakhov, N.M., 1937, On the significance of hydrogen sulfide basins in areas of deposition of bituminous and "oil-producing" suites: Izvest. Akad. Nauk, SSSR, Ser. Geo1. No. 5, p. 893-917 (in Russian). 
Strakhov, N.M., 1947, K poznaniyu zakonomernostei i mekhanizma morskoy sedimentatsii. 1. Chernom more (Toward understanding the mechanisms of marine sedimentation. 1. Black Sea): Moskow, Akad. Nauk SSSR Izv. Ser. Geo1., v. 2, p. 49-90.

Strakhov, N.M., 1954, Osadkoobrazovaniye v Chernom more (Sediment formation in the Black Sea); in: Belyankin, D.S., ed., Obrazovaniye osadkov $v$ sovremennykh (Formation of sediments in contemporary basins), Moscow, Izd. Akad. Nauk SSSR, p. 81-136.

Strickland, J.D.H. and T.R. Parsons, 1968, A handbook of Seawater Analysis: Bul1. Fish. Res. Bd. Canada, v. 167, 311p.

Suess, E., 1979, Mineral phases formed in anoxic sediments by microbial decomposition of organic matter: Geochim. Cosmo. Acta, v. 43, p. 339-352.

Taylor, S.R., 1964, Abundance of chemical elements in the continental crust: a new table: Geochim. Cosmochi. Acta, v. 28, p. 1273-1285.

Thompson, G. and V.T. Bowen, 1969, Analyses of coccolith ooze from the deep tropica1 Atlantic: J. Mar. Res., v. 27, p. 32-38.

Tissot, B.P., 1979, Effects on prolific petroleum source rocks and major coal deposits caused by sea-level changes: Nature, v. 277 , p. $377-380$. 
Trimonis, E.S., 1974, Some characteristics of carbonate sedimentation in Black Sea, in: Degens, E.T. and D.A. Ross (eds.), 1974, The Black Sea -geology, chemistry, and biology, Am. Asso. Petr. Geol,, Mem. 20 , p. 279-295.

Turekian, K.K. and K.H. Wedepoh1, 1961, Distributions of the elements in some major units of the earth's crust: Geo1. Soc. Amer. Bull., v. 72 , p. $175-192$.

UNESC0, 1978, The world water balance and water resources of the earth, Unesco, 563p.

Usatchev, P., 1947, General characteristics of the phytoplankton of the Seas of USSR: Recent Advanc. Bio1., v. 23, p. 2 (Russian).

Vine, A.C., 1974, Bottom photographs of the Black Sea; in: Degens, E.T. and D.A. Ross,, eds., The Black Sea - Geology, Chemistry, and Biology, Amer. Assoc. Petrol. Geo1., Memo. 20, p. 183-199.

Vinogradova, Z.A. and V.V. Koval'skiy, 1962, Elemental composition of the Black Sea plankton: Doklady Akad. Nauk. SSSR, v. 147, p. 217-219. 
Volkov, I.I. and L.S. Fomina, 1974, Influence of organic materia1 and processes of sulfide formation on distribution of some trace melements in deep-water sediments in Black Sea; in: Degens, E.T. and D.A. Ross, The Black Sea - geology, chemistry, and biology, Am. Asso. Petrol. Geol. Mem. 20, p. 456-476.

Wells, J.T., O.K. Huh, and Y.A. Park, 1983, Dispersal of silts and clays by winter monsoon surges in the southeastern Huanghai Sea; in: Proceedings of the Int. Symp. on the Sedimentation on the Continental Shelf, with special reference to the East China Sea, April12-16 1983, Hangzhou, China, China Ocean Press, p. 430-439.

Westerlund, S., 1986, Trace metal concentration in the Black Sea; in: Proceedings, The Chemical and Physical Oceanography of the Black Sea, Int. meeting in Göteborg, June 2-4, 1986.

Wilson, B.W., 1960, Note on surface wind stress over water at low and high wind speeds: J. Geophys. Res., v. 65, p. 3377-3382.

Zenkovitch, V.P., 1966, Black Sea; in: Fairbridge, R.W., ed., 1966, Ency1. of Oceanography, p. 145-151.

Zhorov, V.A., Ye.Ye. Sovga, L.V. Solov'yeva, S.G. Boguslavskiy, and A.Ye. Babinets, 1983, The distribution of copper, zinc, molybdenum, and uranium in Black Sea bottom sediments: Geokhimiya, v. 6, p. 872-880. 